\title{
AN APPLIED ECONOMIC ANALYSIS OF THE DEMAND FOR PORK PRIMAL CUTS
}

A thesis presented to the Faculty of the

Graduate School at the University of Missouri

In Partial Fulfillment of the Requirements

for the Degree Master of Science

by

JAIME LUKE

Dr. Scott Brown, Thesis Supervisor

MAY 2021 
The undersigned, appointed by the Associate Vice Chancellor of the Office of Research and the Graduate Studies, have examined the thesis entitled

\section{AN APPLIED ECONOMIC ANALYSIS OF THE DEMAND FOR PORK PRIMAL CUTS}

Presented by Jaime Luke, a candidate for the degree of Master of Science, and hereby certify that, in their opinion it is worthy of acceptance.

Associate Extension Professor and Director of Strategic Partnerships - Dr. Scott Brown

Director, Division of Applied Social Sciences - Dr. Joe Parcell

Professor and State Swine Extension Specialist - Dr. Tim Safranski 


\section{ACKNOWLEDGEMENTS}

First, I would like to thank Dr. Scott Brown not only for his guidance and assistance in conducting this research but also for agreeing to take me on as a graduate student in the first place. Over the past couple years, Dr. Brown has served as an advisor, mentor, and role model. I am continually inspired by his ability to connect with everyone he meets and positively impact the lives of others through his various roles. Additionally, I would like to thank my committee members - Dr. Joe Parcell and Dr. Tim Safranski. Dr. Parcell has been around for every up and down of my academic career so far and has been a constant supporter and source of advice in times of need. I am forever grateful Dr. Parcell was my first connection at Mizzou, as I believe that has had an enormous impact on my trajectory both as an undergraduate and graduate student. Dr. Safranski is the prime example of a successful, impactful extension faculty member. Throughout my career, I hope to emulate his ability to connect with producers and communicate complex issues seamlessly. His practical knowledge of the swine industry was invaluable in helping me understand the implications of this work.

Second, I give my thanks to the National Pork Board for awarding me the Agrimarketing Fellowship that assisted in making this research happen. Their financial support and swine industry expertise has been integral in producing this work.

I am also grateful for the help of Daniel Madison, who offered a great deal of statistical guidance and modeling expertise, and Darlene Kruse, who meticulously read and offered feedback for every page of this work. I also want to thank those in the Food and Agricultural Policy Research Institute at the University who offered comments on preliminary versions of this work and played vital roles in helping me gather international 
data. I also want to thank those at U.S. Meat Export Federation, USDA Foreign Agricultural Service, and USDA Agricultural Marketing Service who fielded my questions about the intricacies of the data that I used. I appreciate their willingness to explain the complexities and share their industry knowledge.

Finally, I want to thank my family and friends for their support throughout the entire research process. I am especially grateful for my dad, whose love for agriculture has inspired me to study agricultural economics. I feel very blessed to have grown up on a farm working alongside my parents and brothers to raise livestock and grow crops. I also appreciate my fellow graduate students and friends who supported me throughout the ups and downs of writing and defending this thesis. Their kindness and encouragement are truly what got me through. 


\section{TABLE OF CONTENTS}

ACKNOWLEDGEMENTS ............................................................................... ii

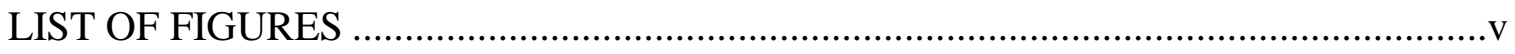

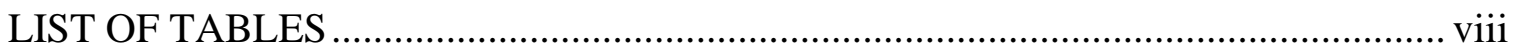

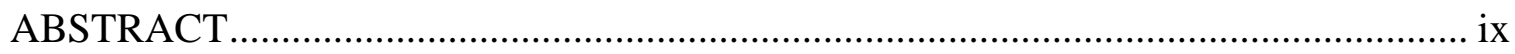

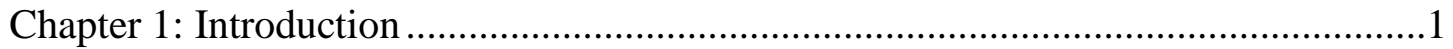

Chapter 1.1: U.S. Pork Demand..................................................................

Chapter 1.2: U.S. Pork Export Markets ............................................................

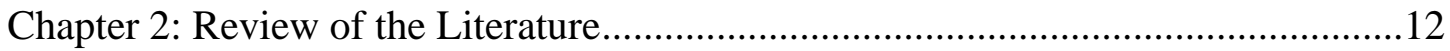

Chapter 2.1: Review of Pork Research ......................................................... 14

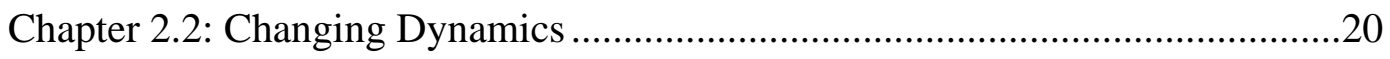

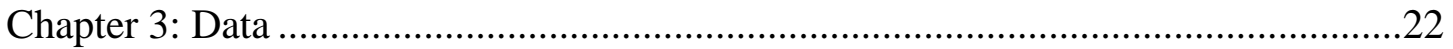

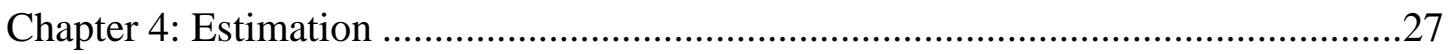

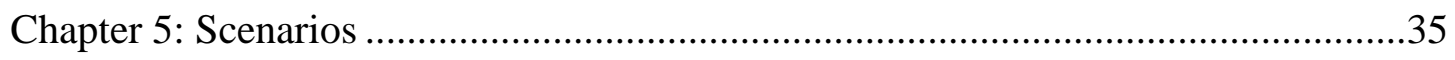

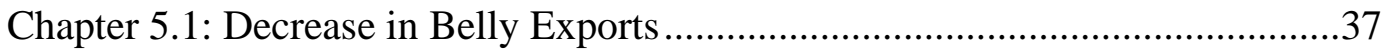

Chapter 5.2: Decrease in Butt Exports........................................................ 42

Chapter 5.3: Decrease in Ham Exports ...........................................................46

Chapter 5.4: Decrease in Loin Exports ............................................................50

Chapter 5.5: Decrease in Picnic Exports..........................................................54

Chapter 5.6: Decrease in Rib Exports ......................................................58

Chapter 5.7: U.S. Pork Exports to China and Mexico .......................................63

Chapter 5.8: Decrease in China Exports ........................................................65

Chapter 5.9: Decrease in Mexico Exports ..................................................69

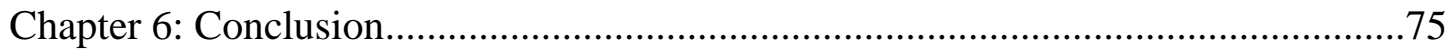

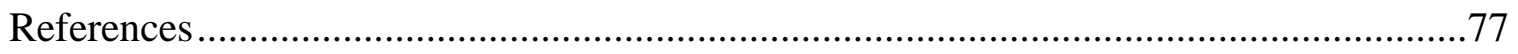

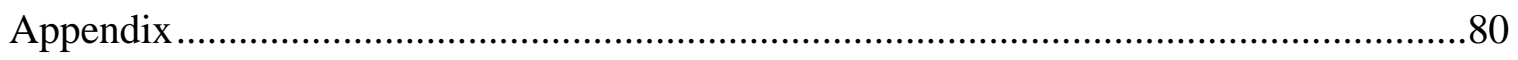




\section{LIST OF FIGURES}

Figure 1 U.S. Retail Pork Prices ................................................................................

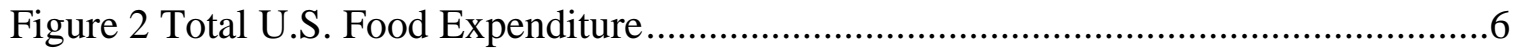

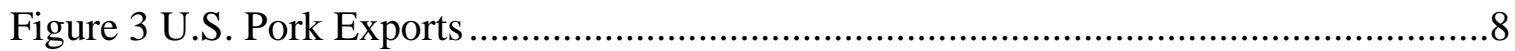

Figure 4 U.S. Pork Exports to Key Markets ...............................................................

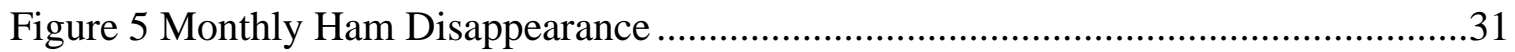

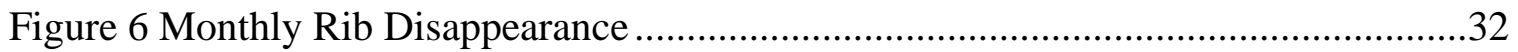

Figure 7 Per Capita Butt Disappearance over Period of Fit, Jan 2010 - Aug 2020 .........33

Figure 8 Per Capita Butt Disappearance outside Period of Fit, Sept 2010 - Dec 2020_....33

Figure 1 Percentage Change in Pork Cutout Value and Production as Result of Monthly 10 Percent Decrease in U.S. Belly Exports from Baseline Values, Jan 2021 - Dec 2025 .

Figure 2 Percentage Change in Exports as Result of Monthly 10 Percent Decrease in U.S. Belly Exports from Baseline Values, Jan 2021 - Dec 2025

Figure 11 Percentage Change in Domestic Disappearance as Result of Monthly 10 Percent Decrease in U.S. Belly Exports from Baseline Values, Jan 2021 - Dec 2025 .

Figure 12 Percentage Change in Pork Cutout Value and Production as Result of Monthly 10 Percent Decrease in U.S. Butt Exports from Baseline Values, Jan 2021 - Dec 2025

Figure 13 Percentage Change in Exports as Result of Monthly 10 Percent Decrease in

U.S. Butt Exports from Baseline Values, Jan 2021 - Dec 2025

Figure 14 Percentage Change in Domestic Disappearance as Result of Monthly 10 Percent Decrease in U.S. Butt Exports from Baseline Values, Jan 2021 - Dec 2025.

Figure 15 Percentage Change in Pork Cutout Value and Production as Result of Monthly 10 Percent Decrease in U.S. Ham Exports from Baseline Values, Jan 2021 - Dec 2025 .

Figure 16 Percentage Change in Exports as Result of Monthly 10 Percent Decrease in U.S. Ham Exports from Baseline Values, Jan 2021 - Dec 2025

Figure 17 Percentage Change in Domestic Disappearance as Result of Monthly 10 Percent Decrease in U.S. Ham Exports from Baseline Values, Jan 2021 - Dec 2025 . 
Figure 18 Percentage Change in Pork Cutout Value and Production as Result of Monthly 10 Percent Decrease in U.S. Loin Exports from Baseline Values, Jan 2021 - Dec 2025 .

Figure 19 Percentage Change in Exports as Result of Monthly 10 Percent Decrease in U.S. Loin Exports from Baseline Values, Jan 2021 - Dec 2025 .52

Figure 20 Percentage Change in Domestic Disappearance as Result of Monthly 10

Percent Decrease in U.S. Loin Exports from Baseline Values, Jan 2021 - Dec

2025 ......

Figure 21 Percentage Change in Pork Cutout Value and Production as Result of Monthly 10 Percent Decrease in U.S. Picnic Exports from Baseline Values, Jan 2021 - Dec 2025 .

Figure 22 Percentage Change in Exports as Result of Monthly 10 Percent Decrease in U.S. Picnic Exports from Baseline Values, Jan 2021 - Dec 2025.

Figure 23 Percentage Change in Domestic Disappearance as Result of Monthly 10 Percent Decrease in U.S. Picnic Exports from Baseline Values, Jan 2021 - Dec 2025

Figure 24 Percentage Change in Pork Cutout Value and Production as Result of Monthly 10 Percent Decrease in U.S. Rib Exports from Baseline Values, Jan 2021 - Dec 2025 .

Figure 25 Percentage Change in Exports as Result of Monthly 10 Percent Decrease in U.S. Rib Exports from Baseline Values, Jan 2021 - Dec 2025.

Figure 26 Percentage Change in Domestic Disappearance as Result of Monthly 10 Percent Decrease in U.S. Rib Exports from Baseline Values, Jan 2021 - Dec 2025

Figure 27 Percentage Change in Production by Primal as Result of Monthly 10 Percent Decrease in U.S. Primal Exports from Baseline Values, Jan 2021 - Dec 2025 ....62

Figure 28 Percentage Change in Pork Cutout Value by Primal as Result of Monthly 10 Percent Decrease in U.S. Primal Exports from Baseline Values, Jan 2021 - Dec 2025 .

Figure 29 U.S. Pork Exports to China, Mexico, and Rest of World (ROW)

Figure 30 Percentage Change in Pork Cutout Value and Production as Result of Monthly 10 Percent Decrease in U.S. Exports to China from Baseline Values, Jan 2021 Dec 2025 
Figure 31 Percentage Change in Pork Primal Cutout Values as Result of Monthly 10 Percent Decrease in U.S. Exports to China from Baseline Values, Jan 2021 - Dec 2025

Figure 32 Percentage Change in Exports as Result of Monthly 10 Percent Decrease in U.S. Exports to China from Baseline Values, Jan 2021 - Dec 2025 .68

Figure 33 Percentage Change in Domestic Disappearance as Result of Monthly 10 Percent Decrease in U.S. Exports to China from Baseline Values, Jan 2021 - Dec 2025 .69

Figure 34 Percentage Change in Pork Cutout Value and Production as Result of Monthly 10 Percent Decrease in U.S. Exports to Mexico from Baseline Values, Jan 2021 Dec 2025

Figure 35 Percentage Change in Primal Cutout Values as Result of Monthly 10 Percent Decrease in U.S. Exports to Mexico from Baseline Values, Jan 2021 - Dec 2025

Figure 36 Percentage Change in Exports as Result of Monthly 10 Percent Decrease in U.S. Exports to Mexico from Baseline Values, Jan 2021 - Dec 2025 .73

Figure 37 Percentage Change in Domestic Disappearance as Result of Monthly 10 Percent Decrease in U.S. Exports to Mexico from Baseline Values, Jan 2021 Dec 2025 


\section{LIST OF TABLES}

Table 1 Summary of Pork Demand Elasticities ................................................................

Table 2 Primal Cutout Yields for Composite Cutout ………………………………......23

Table 3 HS Code to Pork Primal Conversions...................................................................24

Table 4 Pork Primal Per Capita Disappearance Estimate Equations ................................29

Table 5 Production Estimate Equation ...........................................................................

Table 6 Impacts of 10 Percent Decrease in U.S. Belly Exports from Baseline Values, January 2021 - December 2025............................................................................

Table 7 Impacts of 10 Percent Decrease in U.S. Butt Exports from Baseline Values,

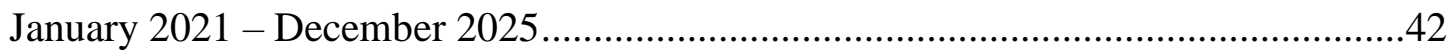

Table 8 Impacts of 10 Percent Decrease in U.S. Ham Exports from Baseline Values, January 2021 - December 2025 .............................................................................

Table 9 Impacts of 10 Percent Decrease in U.S. Loin Exports from Baseline Values, January 2021 - December 2025 ..........................................................................50

Table 10 Impacts of 10 Percent Decrease in U.S. Picnic Exports from Baseline Values, January 2021 - December 2025 ............................................................................

Table 11 Impacts of 10 Percent Decrease in U.S. Rib Exports from Baseline Values, January 2021 - December 2025 .............................................................................

Table 12 USMEF Estimated U.S. Pork Primal Export Shares to China and Mexico in 2020

Table 13 Impacts of 10 Percent Decrease in U.S. Exports to China from Baseline Values, January 2021 - December 2025 .........................................................................65

Table 14 USMEF Estimated Mexico Shares of ROW Exports in 2020 ............................70

Table 15 Impacts of 10 Percent Decrease in U.S. Exports to Mexico from Baseline Values, January 2021 - December 2025 ..................................................................70

Table A1 Belly Supply \& Utilization ...............................................................................

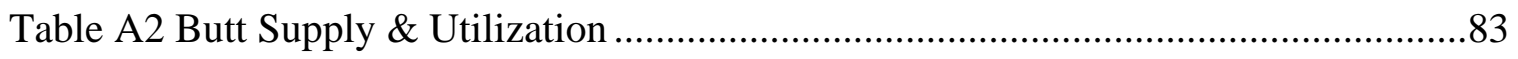

Table A3 Ham Supply \& Utilization .............................................................................

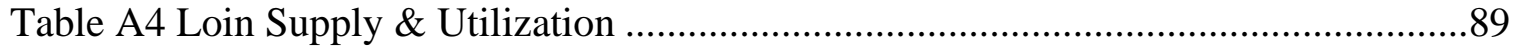

Table A5 Picnic Supply \& Utilization .......................................................................92

Table A6 Rib Supply \& Utilization ...............................................................................95 


\begin{abstract}
This study estimates domestic disappearance equations for the six main pork primal cuts (belly, butt, ham, loin, picnic, and rib) to determine the own-price, cross-price, and income elasticities for each cut. These equations were utilized to develop an economic model of the pork industry that was used to determine the impacts that various trade scenarios could have on monthly disappearance, production, exports, and cutout values both for each primal cut and pork as a whole. It was found that the own-price elasticity of bellies was most inelastic and of loins was least inelastic. Of the primal cuts, decreasing exports of bellies had the most detrimental impact on the pork cutout value. Of the main pork exports markets, decreasing exports to China had the most detrimental impact on the pork cutout value.
\end{abstract}




\section{Chapter 1: Introduction}

The average consumer can effectively observe the differences among pork cuts and make purchasing decisions based on these differences. Few American families dive into a pork jowl on Thanksgiving whereas a Thanksgiving ham is commonplace. Furthermore, a fastfood restaurant may top their most widely requested hamburger with a couple strips of bacon, but they would never consider replacing that bacon with, say, a loin roast.

Differences in cuts of pork go far beyond the contrasting appearances, customary uses, and complimentary food pairings, however. Varying pork cuts also come with varying price tags, which also play a role in determining if consumers will choose ham or turkey, or perhaps choose both, at Thanksgiving dinner this year.

Interestingly, much of the research examining demand for pork that has been pursued up to this point has disregarded separability, or the fact that the commodity of pork is actually an amalgamation of various cuts that comprise the whole carcass of a hog. Each of the cuts could have different demand elasticities. By treating cuts as separate commodities, vital insight may be gained into how pork prices move. The objective of this research is to estimate own-price, cross-price, and income elasticities for the six main pork primal cuts: belly, butt, ham, loin, picnic, and rib. These elasticity estimations are then used to develop an economic model of the pork industry that can estimate the implications various trade scenarios could have on the U.S. pork cutout value.

\section{Chapter 1.1 U.S. Pork Demand}

To understand the prices of pork cuts and their drivers today, it is imperative to be familiar with how the demand for various pork products has evolved over time, and more generally, the basic history of the pork industry as a whole. First, consider pork 
consumption in the United States. Ask U.S. consumers their favorite pork product and myriad answers may ensue. From pork chops to sausage to ribs, pork carcasses offer consumers a gamut of delicious options. However, one product will most likely surface as the frontrunner. Over the past couple decades, the love consumers possess for bacon has skyrocketed. Gone are the days when bacon was solely a breakfast staple. Bacon has successfully found a way to permeate breakfast, lunch, and dinner, and sometimes even the snacks in between. Bacon cheeseburgers, bacon nachos and even bacon ice cream have become offerings on menus in the U.S. In fact, 70 percent of restaurants in the U.S. report serving bacon in some form to their patrons. ${ }^{1}$ This has not always been the case. As can be seen in Figure 1, the bacon frenzy is a relatively current phenomenon that picked up steam in the past decade. Bacon's retail price in the U.S. has more than doubled as compared to what it was in 2000 .

\footnotetext{
${ }^{1}$ Russell, A. (2019, November 12). "Is A Bacon Shortage Coming?” Texas A\&M AgriLife.
} 
Figure 3. U.S. Retail Pork Prices

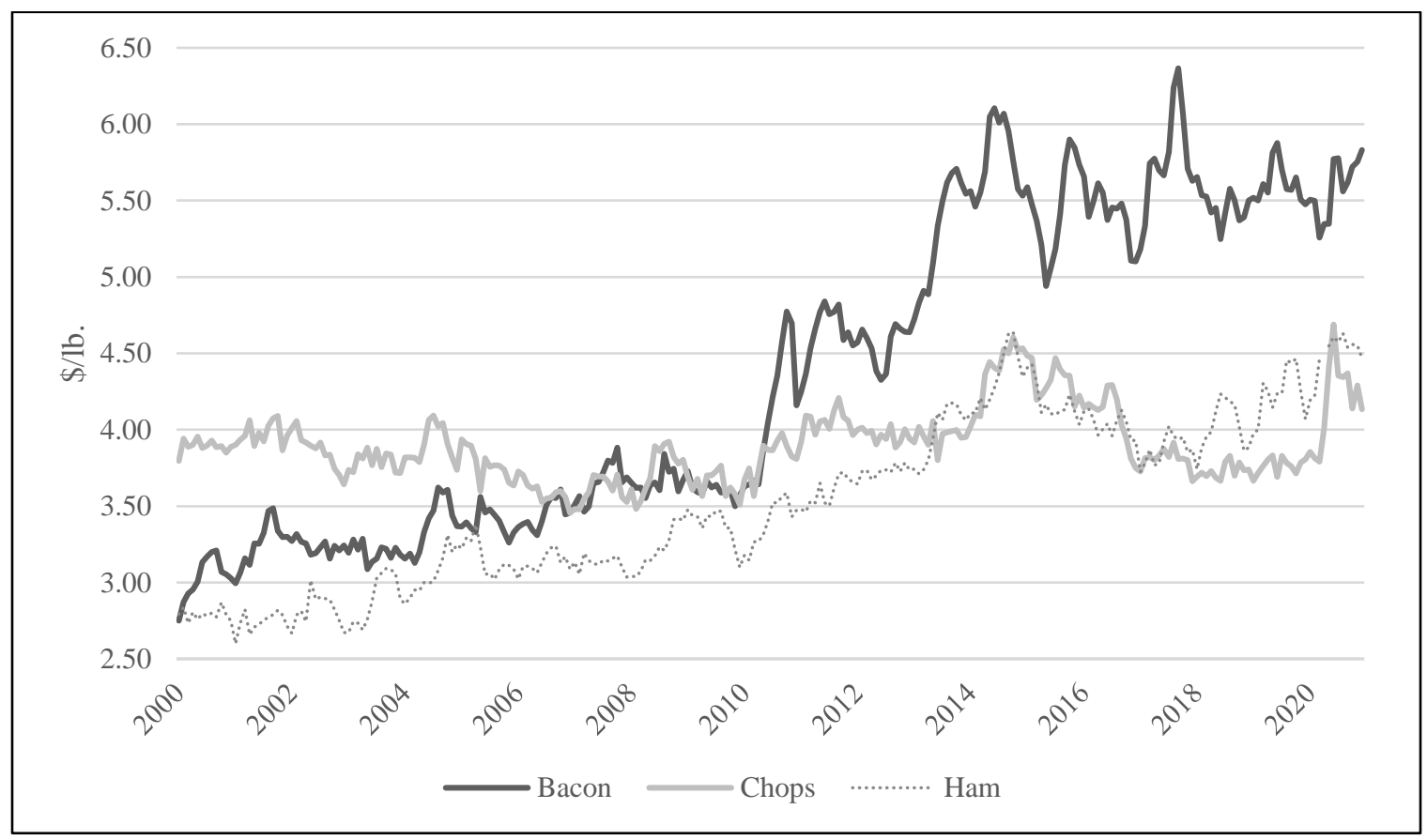

Source: U.S. Bureau of Labor Statistics CPI Average Price Data, U.S. city average

Some attribute bacon's newfound demand surge to the leanness of the modern pork carcass. This characteristic change in pork carcasses leads to leaner bacon that is exceptionally palatable for consumers. ${ }^{2}$ Pork carcasses have evolved to be leaner over time in response to pricing incentives that reward producers for producing a leaner product. According to the United States Department of Agriculture (USDA) Economic Research Service, "As the popularity of carcass pricing programs grew, leaner hogs became available at more desirable weights. Producers introduced new genetics, improved nutrition, and enhanced management that increased growth rates, feed

\footnotetext{
${ }^{2}$ Blythe, B. (2019, June 4). "Bacon Demand Is Higher Than Ever as Price Volatility Grows.” CME Group.
} 
efficiency, and lean meat composition." ${ }^{33}$ Today’s pork has on average 16 percent less fat and 27 percent less saturated fat as compared to what it had in $1991 .{ }^{4}$

Production consolidation in the pork industry also has an impact on the value of pork in the U.S. In 1980 the average U.S. hog operation consisted of about 97 hogs, with a total of 666,500 farms producing hogs across the country. Over the following four decades, the number of hog operations decreased greatly, with the average number of hogs per operation notably increasing. The 2017 USDA Census of Agriculture reported the average number of hogs per operation was nearly 1,100 , and the total number of operations in the U.S. was only $66,439 .{ }^{5}$ As operations have grown in size, the level of investment required to begin and maintain these operations has also increased. This could have implications on the supply elasticity of pork. If producers have a great deal invested in their operations, this could result in them being reluctant to increase or decrease production in response to changes in price, which ultimately effects the value of pork in the U.S.

Others claim bacon's rise is due to restaurants' evolving menus. For example, McDonald's reported a 4.5 percent jump in sales in the first quarter of 2019 when they added "Big Mac Bacon" and "Quarter Pounder Bacon" options to their lineup. Their tagline stated, "Because There's No Such Thing as Too Much Bacon.” Moreover, according to Blythe, bacon ranked third on the National Restaurant Association's

\footnotetext{
${ }^{3}$ Martinez, S. and K. Zering. (October 2004). Pork Quality and the Role of Market Organization. Economic Research Service, United States Department of Agriculture.

${ }^{4}$ National Pork Board. (2021). "Fat In Pork."

${ }^{5}$ USDA National Agricultural Statistics Service. (2020). "Hogs - operations with inventory, Hogs Inventory."
} 
"What's Hot Culinary Forecast" in 2018. This forecast is developed from feedback given by 700 professional chefs. ${ }^{6}$

What restaurants choose to include on their menus may have more influence on the demand for pork cuts today than in the past. Over the past three decades, U.S. consumers have grown to rely more heavily on the convenience of food prepared outside of the home. In 1987, consumers' spending on food prepared at home (FAH) accounted for 56 percent of food expenditure and food away from home (FAFH) accounted for the remaining 44 percent. However, spending on FAFH surpassed spending on FAH for the first time in 2010, and its share continues to increase. ${ }^{7}$ In fact, the shares of FAFH and FAH today have nearly flipped as compared to what they were in 1987 , as can be seen in Figure 2. According to the USDA Economic Research Service, U.S. expenditure on food in 2019 totaled $\$ 1.77$ trillion, and FAFH accounted for 54.8 percent of that, totaling about $\$ 970$ billion. FAH accounted for the remaining 45.2 percent, roughly $\$ 800$ billion in food expenditure. ${ }^{8}$

\footnotetext{
${ }^{6}$ Blythe, B. (2019, June 4). "Bacon Demand Is Higher Than Ever as Price Volatility Grows." CME Group. ${ }^{7}$ Saksena et al. (2018). "America's Eating Habits: Food Away from Home." Economic Research Service, United States Department of Agriculture.

${ }^{8}$ USDA Economic Research Service. (2020). "U.S. food-away-from-home spending continued to outpace food-at-home spending in 2019." Food Expenditure Series.
} 
Figure 4. Total U.S. Food Expenditure

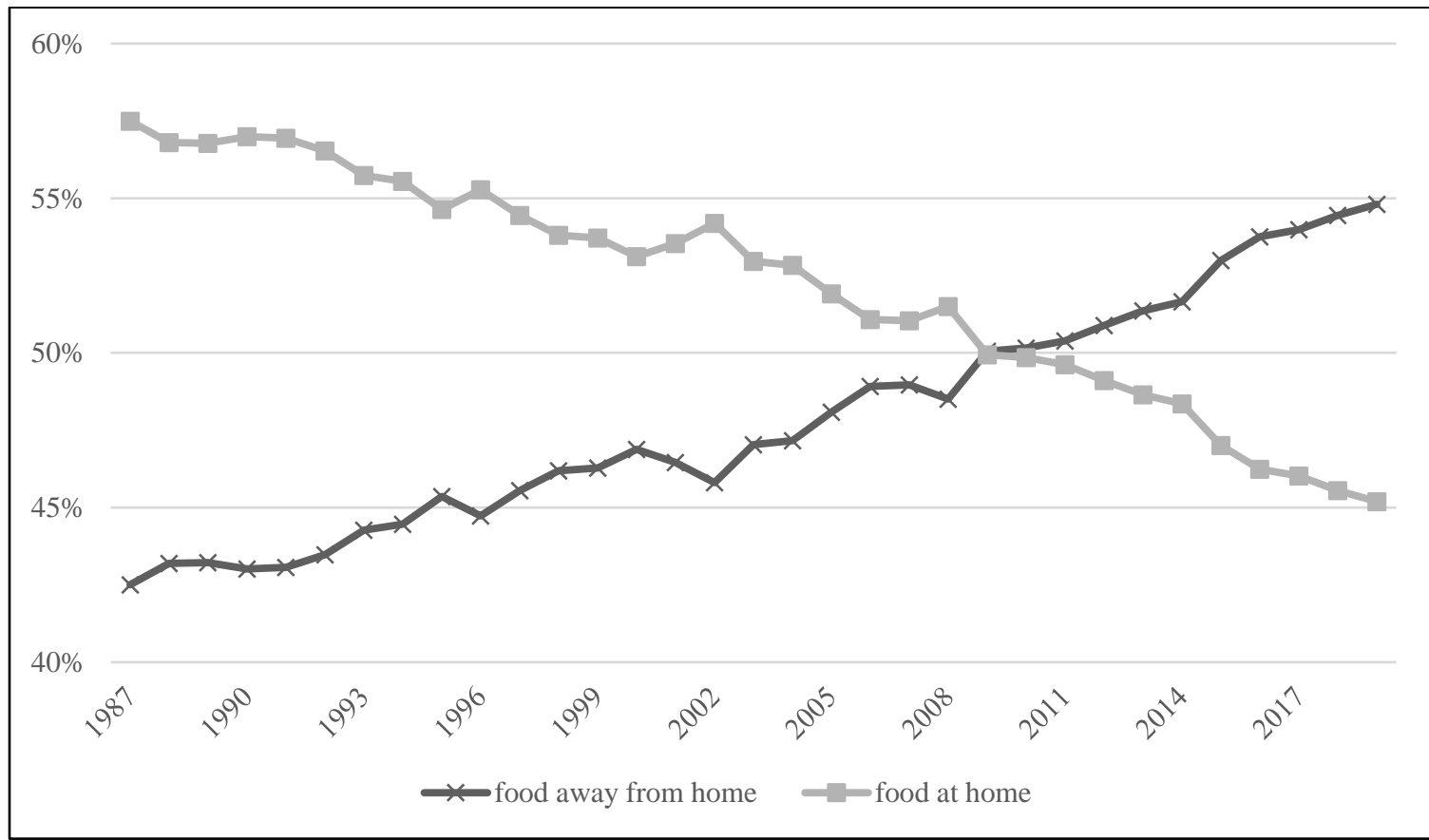

Source: USDA Economic Research Service Food Expenditure Series

The transition of consumers' food expenditure away from their households could have marked effects on the demand for individual pork cuts. Consumers going to the meat case and comparing meat prices to determine what products to purchase holds less of an influence now than in the past. Today, consumers are choosing restaurants with selected meat options, which inherently predetermines which meat cuts they will ultimately consume. This means restaurants possess a great deal of power in determining the demand for various pork products. Of course, restaurants consider what consumers demand when selecting food items to include on their menu. Nevertheless, the myriad of options and ability to easily substitute among meat cuts offered with the grocery store experience is often not the case when purchasing food from a restaurant.

It is worth noting, however, that the Covid-19 pandemic did cause some changes to this trend beginning in the first quarter of 2020 and continuing to present. As restaurants were 
ordered to transition to to-go orders, restrict their seating capacities, or close their doors completely to slow the spread of the virus, consumers increased their food at home consumption. It is unknown the effect that this will have on consumer behavior long term, but it is likely that consumers will resume their spending on food away from home once it is safe to do so and restaurants are able to fully function.

Bacon's all-star status has implications on the broader value of the pork carcass, which in turn affects the price producers receive for their product as well as the price consumers pay in restaurants and grocery stores. After all, bacon is just one retail cut taken from a larger pork carcass. Specifically, bacon is taken from the belly primal cut. If belly demand drives the value of a carcass, what does that mean for the value of other primal cuts like loins and picnics? These cuts can see decreases in value as a result of an overall increase in the production of pork due to producers trying to fill the demand for bellies. How should pork producers target their demand building efforts in order to maximize the value of a whole pork carcass? Questions such as these can be addressed if one dives further into the specifics of the pork carcass to better understand the demands unique to each primal cut.

\section{Chapter 1.2 U.S. Pork Export Markets}

Analyzing pork cuts as individual commodities rather than considering pork as a whole has potential to be of great value considering all that is currently happening in pork markets around the world. First, consider the role that exports play in the demand for U.S. pork. Over the past couple decades, export markets have become increasingly vital to bolstering the value of U.S. pork. As can be seen in Figure 3, pork exports have grown from about 7 percent of total U.S. production in 2000 to over 20 percent in 2019. 
Figure 5. U.S. Pork Exports

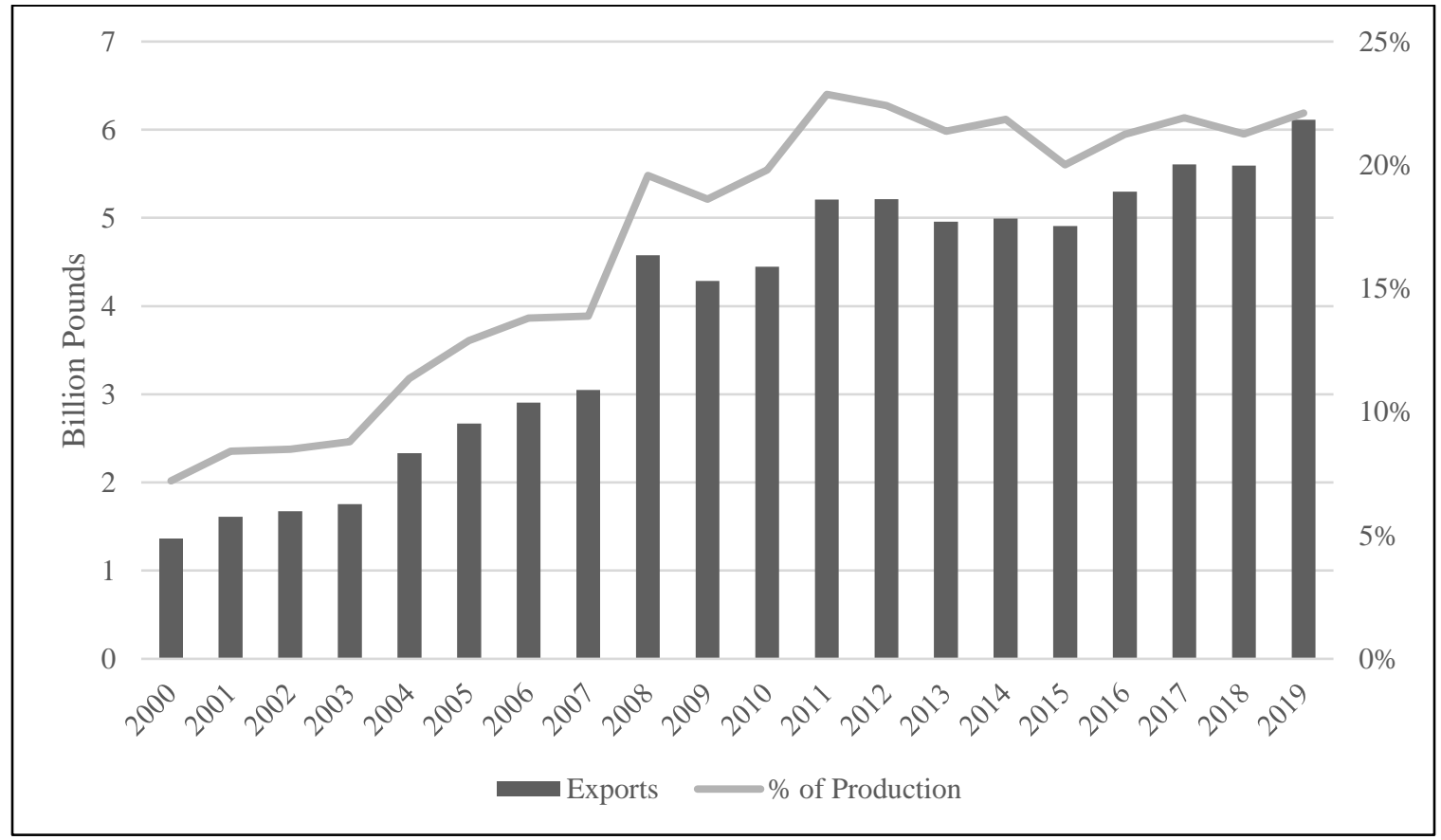

Sources: USDA Foreign Agricultural Service Global Agricultural Trade System \& USDA National Agricultural Statistics Service

Much of this growth can be attributed to increased demand in a few key markets. In 2019, Canada, China, Japan, Mexico, and South Korea accounted for about 78 percent of U.S. pork exported. As can be seen in Figure 4, steady demand growth in the U.S.'s border countries, Canada and Mexico, has been fundamental in increasing U.S. pork exports over the past twenty years. Likewise, the emergence of Asian markets, namely China and South Korea, has played a colossal role in providing export opportunities for U.S. pork. 
Figure 6. U.S. Pork Exports to Key Markets

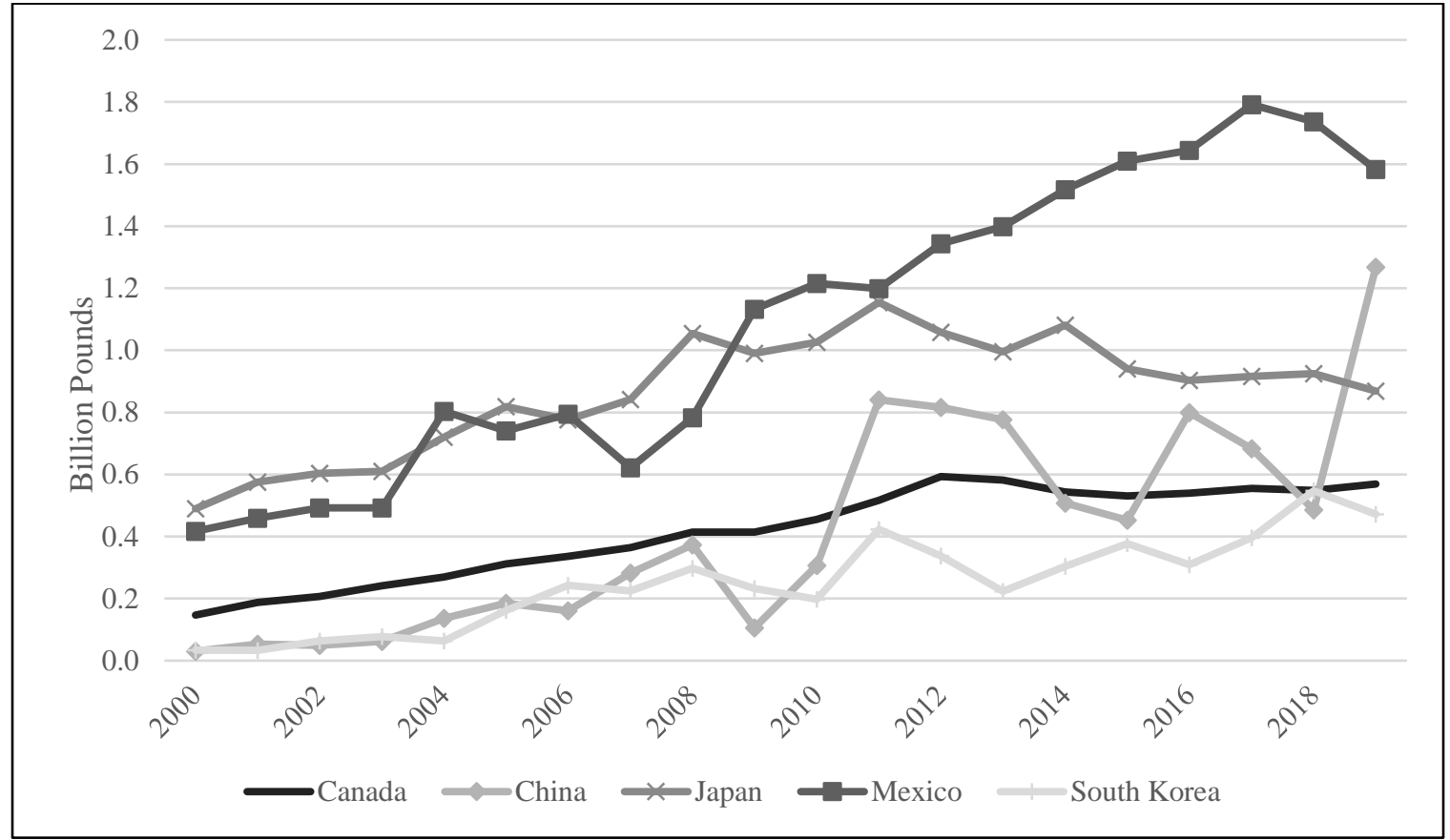

Source: USDA Foreign Agricultural Service Global Agricultural Trade System

China's demand for pork is especially relevant today. In August 2018, China's hog herd was hit with African swine fever (ASF), which is a deadly disease that currently has no treatment or vaccine available. ASF has wreaked havoc on China's pork industry, with pork production in 2020 down nearly 40 percent as compared to 2018 levels. ${ }^{9}$ Consequently, China needs pork imports now more than ever. In addition, the United States and China have an ongoing trade battle that looms over the situation. In April 2018, the United States imposed tariffs on $\$ 50$ billion of Chinese products. To retaliate, China placed tariffs on U.S. products valued at $\$ 50$ billion. Among these was an additional 25 percent tariff on U.S. pork. Over the next eighteen months, additional retaliatory tariffs were placed on U.S. pork, and by September 2019, some U.S. pork

\footnotetext{
${ }^{9}$ Haley, M. and F. Gale. (2020, February 3). "African Swine Fever Shrinks Pork Production in China, Swells Demand for Imported Pork.” Economic Research Service, United States Department of Agriculture.
} 
exports to China were facing up to a 72 percent duty. ${ }^{10}$ In October 2019, it was

announced that the U.S. and China had reached a Phase 1 deal that implied China should be purchasing $\$ 36.5$ billion in U.S. agricultural products in 2020 and $\$ 43.5$ billion in 2021. Although China imports of U.S. agricultural products expanded in 2020, they fell short of reaching the 2020 target; reaching the 2021 target seems similarly unlikely. ${ }^{11}$

The situation in China is complex and everchanging and has the potential to be either a substantial opportunity or a crushing blow for U.S. pork producers depending on what happens in the coming months and years. Similarly, the Covid-19 pandemic has introduced another layer of uncertainty. Covid-19 has impacted pork markets around the world. The U.S. has seen supply chains disrupted, and restaurants have had to close their doors, leading to more demand for food at home and less demand for food away from home. Food systems, including those for pork, have been shocked in one way or another impacting who eats what and how much of it. The effects of the pandemic will undoubtedly be experienced well into the future.

As one can see, the U.S. pork industry is in a unique position. The decisions being made today will prove to be paramount to the vitality of the U.S. pork industry into the future. If pork is solely considered as a whole commodity, a great deal of useful information may be overlooked. Take for example the demand for U.S. pork in China as mentioned above. Because Chinese consumers demand different cuts of pork than U.S. consumers, it is careless to assume that a change in demand for pork in China would impact the U.S. pork

\footnotetext{
${ }^{10}$ United States Meat Export Federation. (2020, March 2.) "Retaliatory Duties on U.S. Beef and Pork Products as of March 2, 2020."

${ }^{11}$ Westhoff, P. (2020, October 8). "U.S.-China agricultural trade dispute and the Phase 1 deal." [PowerPoint slides]. University of Missouri Food and Agricultural Policy Research Institute.
} 
cutout value the same way a change in demand for pork in the U.S. would. These disparities are the crux of the current work. The following research estimates the demand for pork primal cuts and develops a model that utilizes these estimates to show the potential impacts various scenarios could have on the U.S. pork cutout value. The information garnered can be used to influence decision making from the farmer to the consumer and the numerous stakeholders in between by providing vital insights into the intricacies of pork demand in the United States and beyond.

Chapter 2 reviews the existing literature on pork demand. Chapter 3 outlines the data used in the research, and chapter 4 summarizes the estimation results. In chapter 5, scenarios are run and explained. Chapter 6 summarizes the research and offers a conclusion. 


\section{Chapter 2: Review of the Literature}

Economic theory provides a framework to understand the decision-making process of consumers, and more importantly, what factors affect consumers' demand for goods and services. Put simply, consumers purchase a large number of goods and services. Some of these, as this research will dive further into, are food items. Others include household items, automobiles, and so forth. Most of the time, the decision for consumers to purchase an item, such as a cut of meat, is not made independently of their total bundle of purchases. Rather, consumers make purchasing decisions with reference to the purchase of other items due to the budget constraint they face. With a fixed amount of money to spend, consumers attempt to maximize utility by choosing the optimal bundle of goods and services they are able to purchase. ${ }^{12}$

Because of the restrictive nature of their budget, consumers often face tradeoffs. As the price of one good increases, they may choose to substitute that good with a similar, less expensive good, or they may choose to forgo purchasing that type of good altogether. Conversely, as a good becomes cheaper, consumers may add it into their bundle in the place of a more expensive good. Furthermore, consumers' budgets can vary over time with changes in income. As consumers' incomes increase, they have more freedom in choosing their optimal bundle of goods and services, and they can purchase more goods and services. Additionally, it is important to note that each consumer has his or her own tastes and preferences that influence final purchasing behaviors. A consumer who prefers vegetarian options may purchase no meat products but purchase a great deal of beans,

\footnotetext{
${ }^{12}$ Smallwood, D., Haidacher, R.C., and Blaylock, J.R. (1987). A review of the research literature on meat demand. Economic Research Service, United States Department of Agriculture.
} 
nuts, and grains to substitute for the protein that meat would have provided in a diet. Ultimately, the described decision-making process implies that the quantity demanded of a good or service is a function of the price of the good or service, the price of every other good or service, the income of consumers, and the consumers' tastes and preferences. ${ }^{11}$

In economics, elasticities are calculated to describe how consumers alter their consumption choices in response to changes in prices and income. Own-price elasticities measure the percentage change in the quantity demanded of a good or service in response to the percentage change in price of the good or service. Goods with own-price elasticities greater than one are considered price elastic, meaning that as the price of a good increases by one percent, the quantity demanded decreases by more than one percent. On the other hand, goods with own-price elasticities less than one indicate they are price inelastic, which means that a one-percent increase in the price of a good translates to a less than one percent decrease in the quantity demanded of that good. ${ }^{13}$ Similarly, cross-price elasticities measure the demand responsiveness of a good to the change in price of another good. If the demand for a good increases as the price of another good increases, then the cross-price elasticity is positive, and the goods are substitutes. On the other hand, negative cross-price elasticities imply that the goods are complements, which means that as the price of one good increases, the demand for another good decreases. ${ }^{12}$

Income elasticities measure the demand responsiveness of a good to a change in income. Positive income elasticities indicate the good is normal; as consumers' incomes increase,

\footnotetext{
${ }^{13}$ Hall, R.E., and M. Lieberman. (2005). Microeconomics: Principles and Applications. ( $3^{\text {rd }}$ ed.). Mason, Ohio: Thomson South-Western. pp. 99-100.
} 
they demand more of a good. Negative income elasticities indicate the good is inferior. An increase in consumers' incomes results in less of a good being demanded. ${ }^{12}$

Developing demand equations and calculating elasticities provide economists with a greater understanding of consumers' purchasing behavior, which, in turn, can aid stakeholders in making sound decisions in creating policies, allocating resources, and much more.

\section{Chapter 2.1 Review of Pork Research}

Numerous economists have conducted research that seeks to understand U.S. pork demand. Dating back to the post-World War II era, the body of work that exists exploring this topic is abundant. However, the majority of the relevant work completed in this field was published in the 1980s and 1990s, and there is little new research available that describes recent changes in consumer behavior for pork.

Leuthold and Nwagbo used both monthly and quarterly data from 1964 to 1975 to estimate demand elasticities for beef, pork, and broilers from single equation models. The study found that estimated monthly and quarterly demand elasticity for pork were -0.83 and -0.82 , respectively. Estimated monthly and quarterly cross-price elasticity with respect to beef were 0.24 and 0.29 , respectively. Estimated monthly cross-price elasticity of pork with respect to broilers was 0.12 . Quarterly cross-price elasticity of pork with respect to broilers was not statistically different from zero. The estimated monthly and quarterly income elasticities for pork were 0.53 and 0.48 , respectively. ${ }^{14}$

\footnotetext{
${ }^{14}$ Leuthold, R.M., and E. Nwagbo. (1977). "Changes in the Retail Elasticities of Demand for Beef, Pork, and Broilers." Illinois Agricultural Economics, 17(2), 22-27.
} 
Likewise, Nyankori and Miller used quarterly data from 1965 to 1979 to construct single equation models and computed the own-price elasticity of pork to be -0.39 over the period and the income elasticity to be 0.60 . Cross-price elasticities of pork with respect to beef and chicken were -0.28 and 0.20 , respectively. ${ }^{15}$

Haidacher et al. used annual data spanning from 1950 to 1977 to estimate domestic demand elasticities for meats using a demand system. This study found that the own-price elasticity for pork was -0.73 ; the cross-price elasticities of pork with beef and chicken were 0.16 and 0.10 , respectively. This indicates at least some degree of substitutability among pork and other prominent meats demanded in the U.S. The estimated income elasticity of pork was found to be 0.50 , which suggests pork is a normal good. ${ }^{16}$

Huang created a demand system for forty food items and one non-food item using data from 1953 through 1983 to illustrate the interdependent nature of food demand at the disaggregated level. Similar to the work of Haidacher et al., this system estimated the own-price elasticity for pork to be -0.73 . Cross-price elasticities of pork with respect to beef and chicken were 0.19 and 0.09 , respectively, which indicates substitutability with each of the meat products. The income elasticity of pork, estimated to be 0.44 , suggests pork is a normal good. ${ }^{17}$

Chavas developed a method for investigating structural change within the meat sector, which resulted in the average estimated own-price elasticity of pork throughout the 1970s

\footnotetext{
${ }^{15}$ Nyankori, J.C.O., and G.H. Miller. (1982). "Some Evidence and Implications of Structural Change in Retail Demand for Meats." Southern Journal of Agricultural Economics, 14(2), 65-70.

${ }^{16}$ Haidacher, R.C., J.A. Craven, K.S. Huang, D.M. Smallwood, and J.R. Blaylock. (1982). "Consumer Demand for Red Meats, Poultry, and Fish." Economic Research Service, United States Department of Agriculture. Report No. AGES820818.

${ }^{17}$ Huang, K.S. (1986). "U.S. Demand for Food: A Complete System of Price and Income Effects." Economics Research Service, United States Department of Agriculture. Technical Bulletin No. 1714.
} 
at -0.71 . The average estimated income elasticity was 0.44 , and the average estimated cross-price elasticities with respect to beef and chicken were 0.20 and 0.07 , respectively. Additionally, his work found that, unlike poultry and beef, little structural change had occurred in the elasticities for pork during the decade of the 1970s. ${ }^{18}$

${ }^{18}$ Chavas, J.P. (1982). "Structural Change in the Demand for Meat." American Journal of Agricultural Economics, 65(1), 148-153. 
In summary, Table 1 encompasses the notable research that includes estimated elasticities

of pork:

Table 1. Summary of Pork Demand Elasticities

\begin{tabular}{|l|c|c|c|c|c|}
\hline \multicolumn{1}{|c|}{ Study } & $\begin{array}{c}\text { Estimation } \\
\text { Period }\end{array}$ & $\begin{array}{c}\text { Own-Price } \\
\text { Elasticity }\end{array}$ & $\begin{array}{c}\text { Income } \\
\text { Elasticity }\end{array}$ & $\begin{array}{c}\text { Cross-Price } \\
\text { Elasticity }\end{array}$ & $\begin{array}{c}\text { Cross-Price } \\
\text { with respect to }\end{array}$ \\
\hline $\begin{array}{l}\text { Leuthold and } \\
\text { Nwagbo (1977) }\end{array}$ & $1964-1975$ & -0.83 & 0.53 & 0.24 & Beef \\
\hline $\begin{array}{l}\text { Nyankori and } \\
\text { Miller (1982) }\end{array}$ & $1965-1979$ & -0.39 & 0.60 & -0.28 & Broilers \\
\hline $\begin{array}{l}\text { Haidacher et al. } \\
(1982)^{3}\end{array}$ & $1953-1977$ & -0.73 & 0.48 & 0.12 & Chicken \\
\hline Huang (1986) & $1953-1983$ & -0.73 & 0.44 & 0.19 & Beef \\
\cline { 5 - 6 } & & & & 0.10 & Chicken \\
\hline Chavas (1982) & $1970-1979$ & -0.71 & 0.44 & 0.20 & Beef \\
\cline { 5 - 6 } & & & & 0.07 & Chicken \\
\hline
\end{tabular}

${ }^{1}$ Single equation model estimated monthly per capita consumption as a function of the deflated retail price of beef, pork, and broilers, the deflated personal income per capita, and a set of dummy variables to account for regular monthly shifts in demand otherwise unquantified. Data used in the model came from the U.S. Department of Agriculture (USDA) and the U.S. Department of Commerce.

${ }^{2}$ Single equation model estimated quarterly per capita consumption quantity of each commodity as a function of own price, prices of other meats, income, and a seasonal dummy variable. Retail level data from several issues of Food Consumption, Prices and Expenditures, and Livestock and Meat Statistics were used.

${ }^{3}$ Demand system model contained 42 food commodities and nonfood. Quantity variables are based on annual USDA per capita disappearance data and price variables are the corresponding BLS price indices. ${ }^{4}$ Demand system model was comprised of 40 food items and 1 nonfood item. Annual data used came from USDA, U.S. Department of Commerce, and U.S. Department of Labor.

${ }^{5}$ Linear model was based on the Kalman filter using annual data from 1950-1970. Data used to estimate this model are U.S. per capita consumptions of poultry, beef, and pork and per capita disposable income. Prices are retail prices for poultry, beef, and pork. Prices for other commodities in the budget are measured by a single price index.

The majority of the research estimates demand for meat commodities holistically rather than recognizing that consumers may demand certain cuts of a meat commodity more than others. Eales and Unnevehr identified this gap and published work that sought to determine if individual subgroups, distinct from the aggregate commodity, have significantly different elasticities and how disaggregation of composite meat groups into 
component subgroups allows for the identification of sources of structural change in meat demand. Using annual data from 1965 to 1985 and two dynamic almost ideal demand systems, one with aggregated meat products and one with disaggregated meat products, it was found that the disaggregated model revealed more complex relationships among meat products than the aggregated model. Additionally, the compensated own-price and income elasticity of pork in the aggregate meat demand system were -0.762 and 0.278 , respectively. In the disaggregated model, the compensated own-price and income elasticity of pork were -0.565 and 0.040 , respectively. ${ }^{19}$

Capps et al. built off the work of Eales and Unnevehr and published a study that estimated the elasticities of twelve beef cuts at the wholesale level. Using data spanning from 1980 through 1990, it was estimated that the own-quantity flexibilities for all cuts are negative, as expected. The cross-product flexibilities for beef cuts with respect to pork are positive and significant, except for fresh 50 and fresh 90 trimmings, which does not support the notion of substitution between beef and pork. The research also revealed that the composite quantity of other beef cuts was not typically a significant factor affecting individual wholesale beef cut prices, which is probably due to the fixed proportion of cuts to each carcass. ${ }^{20}$

Parcell and Pierce examined factors affecting wholesale poultry prices to provide poultry processors and producers more understanding into how consumer purchasing patterns impact the price of poultry. Their work found that own-cut and cross-cut flexibilities

\footnotetext{
${ }^{19}$ Eales, J.S., and L.J. Unnevehr. (1988). "Demand for Beef and Chicken Products: Separability and Structural Change." American Journal of Agricultural Economics, 70(3), 521-532.

${ }^{20}$ Capps, O., Jr., D.E. Farris, P.J. Byrne, J.C. Namken, and C.D. Lambert. (1994). "Determinants of Wholesales Beef-Cut Prices.” Journal of Agricultural and Applied Economics, 26(1), 183-199.
} 
were unique to individual cuts and that there were seasonal differences among the prices of cuts. ${ }^{21}$

Lusk et al. published work that estimated meat retailer own-price and cross-price demand elasticities for USDA Choice and Select boxed beef in order to determine price sensitivity of the USDA beef quality grades as well as the substitutability between the grades and among other meat products. Using monthly data from July 1987 through December 1999, it was found that meat retailers have more elastic demand for lower quality graded beef and that retail beef price has a strong positive relationship with Choice and Select boxed beef demand and a strong negative relationship with wholesale pork and chicken demand. They estimated a wholesale pork demand elasticity of -0.471 , which is consistent with the traditional concept of derived demand where one would expect wholesale demand elasticities to be lower in absolute value than retail demand elasticities. In addition, they found that pork is a substitute for both Choice and Select beef and chicken. ${ }^{22}$

Parcell examined pork at the primal level. This research sought to estimate the wholesale pork primal demand relationship to determine own-quantity price flexibilities. Using monthly data from February 1989 to December 1999, the study estimated the following primal cut own-quantity price flexibilities ${ }^{23}$ :

- Pork loin: -0.49

- Butt: -0.49

\footnotetext{
${ }^{21}$ Parcell, J. and V. Pierce. (2001) "Factors Affecting Wholesale Poultry Prices." Journal of Agricultural and Applied Economics, 32(3), 471-478.

${ }^{22}$ Lusk, J.L., T.L. Marsh, T.C. Schroeder, and J.A. Fox. (2001). "Wholesale Demand for USDA Quality Graded Boxed Beef and Effects of Seasonality." Journal of Agricultural and Resource Economics, 26(1), 91-106.

${ }^{23}$ Parcell, Joe L. (2003). "An Empirical and Analysis of the Demand for Wholesale Pork Primals: Seasonality and Structural Change.” Journal of Agricultural and Resource Economics, 28(2), 335-348.
} 
- Belly: -0.27

- Picnic: -0.24

- Rib: 0.03

- Ham: 0.05

It is important to note that estimated flexibilities for rib and ham were not statistically significant. The main conclusion from the work was that disaggregated price flexibilities are significantly different from aggregate wholesale price flexibilities reported in previous research. If one assumes that the lower limit of elasticities can be derived from taking the inverse of price flexibilities, then the price elasticities of the primal cuts estimated by Parcell are more elastic than the aggregate price elasticity estimated by Lusk et al. of -0.471 . This is consistent with economic theory that asserts that aggregates are typically less elastic due to having fewer options for substitutes. ${ }^{24}$

\section{Chapter 2.2 Changing Dynamics}

As mentioned in the introduction, consumers are transitioning away from food prepared at home and are instead opting to consume food away from home. Therefore, using more current data to estimate demand for pork may lead to different results than in the past and has the potential to uncover new, valuable information that could ultimately impact the future of the pork industry.

Furthermore, updating the research in this field is especially worthwhile considering the triumphs and perils facing America's pork producers and the pork industry today. From African swine fever plaguing some of the United States' most prominent pork export markets to the Covid-19 pandemic affecting consumers' purchasing choices both

\footnotetext{
${ }^{24}$ Parcell, Joe L. (2003). "An Empirical and Analysis of the Demand for Wholesale Pork Primals: Seasonality and Structural Change." Journal of Agricultural and Resource Economics, 28(2), 335-348.
} 
domestically and abroad, those who raise and market swine have ample challenges as well as opportunities on their horizon. Since 1986, U.S. pork producers have effectively funded a checkoff program whose aim is to strengthen the position of pork in the marketplace and to meet past and current marketing challenges. The three main pillars of the pork checkoff program are education, promotion, and research. ${ }^{25}$ While there is no single most-effective method to allocating the expenditure of checkoff funds, analysis of demand data can shed light on the nuances of domestic pork disappearance and the copious factors that contribute to the overarching trends. Estimation of own-price, crossprice, and income elasticities for each of the six primal cuts will be advantageous as the pork industry determines where to focus demand-building efforts in order to provide the greatest value to pork producers into the future. Therefore, while this work is focused on researching pork demand, it has the potential to influence the promotion arm of the checkoff program, as well.

\footnotetext{
${ }^{25}$ Pork Promotion, Research, and Consumer Information Act of 1985. 7 U.S.C. § 4801-4819 (1985).
} 


\section{Chapter 3: Data}

In order to derive domestic disappearance, historic monthly supply and utilization tables were developed for each of the six primal cuts. Including the remaining cuts in a category labeled "variety cuts" was considered. However, unlike the six main cuts, the USDA does not estimate a primal cutout value for variety cuts. Additionally, consider the market for variety cuts. In 2020, nearly 60 percent of exported pork variety cuts went to China. However, pork variety cuts only accounted for 4 percent of all the pork that was exported to China in $2020 .^{26}$ The impact of pork variety cuts on the pork cutout value is most likely not substantial. Thus, a variety cut category was ultimately not included in this work.

The developed tables span from January 2010 through August 2020, resulting in 128 observations per primal cut. These tables are included in the Appendix. Domestic disappearance is calculated as the sum of beginning stocks, production, and imports less exports and ending stocks.

Beginning and ending stock data and total pork production data were provided by USDA's National Agricultural Statistics Service (NASS). Production of the six primal cuts was calculated by multiplying total pork production by carcass yields published by USDA's Agricultural Marketing Service (AMS). These yields can be found in Table 2 and are based on the results of an AMS survey of U.S. pork packers that was completed in July 2019. As shown, the six main primal cuts comprise over 92 percent of the carcass. The remaining 7.71 percent includes variety meats as well as cut loss. ${ }^{27}$ The assumption

\footnotetext{
${ }^{26}$ USDA Foreign Agricultural Service Global Agricultural Trade System. (2021). Available at https://apps.fas.usda.gov/gats/default.aspx. [Accessed March 2021].

${ }^{27}$ USDA Agricultural Marketing Service. (Jan 2020). "A User's Guide to USDA's Pork Carcass Cutout."
} 
was made that the cutout yields of the average pork carcass have not changed drastically over the past decade. While it is possible that there has been some variation in cutout yields over the years, most likely the changes have been minor and would not have a considerable impact on the results of this research.

Table 2. Primal Cutout Yields for Composite Cutout

\begin{tabular}{|l|r|}
\hline \multicolumn{2}{|l|}{ Primal Yield to Carcass } \\
\hline Belly & $16.43 \%$ \\
\hline Butt & $10.27 \%$ \\
\hline Ham & $24.56 \%$ \\
\hline Loin & $25.12 \%$ \\
\hline Picnic & $11.25 \%$ \\
\hline Rib & $4.66 \%$ \\
\hline Jowl & $1.47 \%$ \\
\hline Neck Bones & $1.77 \%$ \\
\hline Tail & $0.18 \%$ \\
\hline Front Feet & $1.03 \%$ \\
\hline Hind Feet & $1.34 \%$ \\
\hline Cut Loss & $1.92 \%$ \\
\hline Source: USDA Agricultural Marketing Service
\end{tabular}

Import and export trade data were provided by USDA's Foreign Agricultural Service's (FAS) Global Agricultural Trade System. These data follow harmonized system (HS) codes that can be vague and do not always seamlessly align with the six primal cuts. With help from industry experts at U.S. Meat Export Federation and National Pork Board, assumptions were made to convert the data from HS codes to each of the primal cuts. Table 3 summarizes these assumptions. 
Table 3. HS Code to Pork Primal Conversions

\begin{tabular}{|c|c|c|c|c|c|c|}
\hline HS Code & Belly & Butt & Ham & Loin & Picnic & Rib \\
\hline $\begin{array}{l}203110000 \\
203192000 \\
203192090 \\
203194000 \\
203194090 \\
203210000 \\
203292000 \\
203294000 \\
210190000 \\
210190090 \\
1602492000 \\
1602494000 \\
1602497000 \\
1602499000 \\
\end{array}$ & $16.43 \%$ & $10.27 \%$ & $24.56 \%$ & $25.12 \%$ & $11.25 \%$ & $4.66 \%$ \\
\hline $\begin{array}{l}203121000 \\
203121020 \\
203129000 \\
203129020 \\
203221000 \\
203229000 \\
210110000 \\
210110020 \\
\end{array}$ & & $22.29 \%$ & $53.30 \%$ & & $24.41 \%$ & \\
\hline $\begin{array}{l}1602422000 \\
1602422020 \\
1602422040 \\
1602424000 \\
\end{array}$ & & $47.72 \%$ & & & $52.28 \%$ & \\
\hline $\begin{array}{l}203194010 \\
210120020 \\
210120040\end{array}$ & $100 \%$ & & & & & \\
\hline $\begin{array}{l}203121010 \\
203129010 \\
210110010 \\
1602411000 \\
1602412000 \\
1602412020 \\
1602412040 \\
1602419000 \\
\end{array}$ & & & $100 \%$ & & & \\
\hline $\begin{array}{l}210190010 \\
1601002010 \\
1601002090\end{array}$ & & & & $100 \%$ & $100 \%$ & \\
\hline 203192010 & & & & & & $100 \%$ \\
\hline
\end{tabular}


Some of the assumptions were straightforward. HS code 210120020, for example, is used to label bacon. It was easy to classify all imports and exports with this HS code as bellies. Many of the HS codes were more complicated to convert to primal cuts, and the primal yields outlined in Table 2 were again utilized. Take for example HS code 203292000. This HS code refers to processed and frozen meat of swine not elsewhere specified or indicated. Because this description is ambiguous and does not allude to any specific cut, exports and imports classified as this code were broken down according to the carcass yields.

On the ambiguity spectrum, some HS codes fell between the past two examples. HS code 203121020 labels processed hams and shoulders. This narrows the focus to three cuts: butts, hams, and picnics. In order to convert this code to primal cuts, the carcass yields of the three cuts were aggregated. Each cut's yield was then divided by that total in order to derive percentages to allocate the export and import volumes. In this case, the percentages for butt, ham, and picnic were $22.29,53.30$, and 24.41, respectively. Unfortunately, this systematic approach undoubtedly possesses imperfections, but a best effort was made to allocate the vague HS codes into primal cut categories as accurately as possible so that the domestic disappearance for each cut could be derived and demand equations could be estimated.

Livestock Marketing Information Center (LMIC) provided monthly USDA estimated pork primal cutout values for each of the six cuts. These values are based on negotiated sales (FOB plant). It is important to note that these prices were reported on a voluntary basis until January 2013 when mandatory price reporting was implemented. When examining the data, significant differences between data from the two reporting periods 
were not found, so voluntarily reported data from January 2010 through December 2012 and mandatorily reported data thereafter were utilized.

LMIC also supplied monthly average national weekly boxed beef cut prices, monthly retail composite chicken prices, monthly retail whole frozen turkey prices, and monthly retail ground beef prices. LMIC compiled the boxed beef prices from USDA Agricultural Marketing Service data; the retail prices were compiled by LMIC from reports of the U.S. Bureau of Labor Statistics. These prices were used to calculate cross-price elasticities of meat substitutes and complements for the pork primal cuts.

The Federal Reserve Bank of St. Louis provided monthly data for U.S. real disposable income, U.S. population, and U.S. consumer price index (CPI). Income and population data were used to calculate income elasticities for each of the six primal cuts.

Additionally, the population data were used to calculate per capita disappearance for each of the cuts. CPI data were used to convert the nominal wholesale and retail meat values outlined above into real values in order to account for inflation over the observation period. 


\section{Chapter 4: Estimation}

Individual demands for the six main pork primal cuts were estimated using single equation ordinary least squares (OLS) regressions. Calculating OLS estimators defines the slope and intercept of a regression by minimizing the sum of the squared residuals in order to come to a "best fit" solution. ${ }^{28}$ While single equation models may fit data better than other functional forms, they often do not conform to demand theory that suggests demand for a product is a function of all prices and income. ${ }^{29}$ For this reason, some may argue that this research would be better suited as a demand system, which would be consistent with demand theory. However, given that the focus of this work is estimating pork demands at the primal level, the extension of primal demand estimation using a system approach is outside the scope of this thesis.

Using the data outlined in Chapter 3, regression models were estimated for disappearance per capita for each pork primal and are summarized in Table 4. For this analysis, equations are specified as the natural logarithm of the variables. The logarithmic form was chosen so that the parameter estimates are own-price, cross-price, and income elasticities, excluding the intercept and dummy variables. Note also that substitution among pork primal cuts was considered, and loins proved to be a statistically significant substitute for each of the other cuts. This is potentially caused by loins comprising the greatest percentage of the pork carcass. However, when loins were included as substitutes

\footnotetext{
28 Stewart, Brandon. (2016, October 10). "Simple Linear Regression.” [PowerPoint slides]. Princeton University. Available at https://scholar.princeton.edu/sites/default/files/bstewart/files/lecture5slides.pdf [Accessed February 2021.]

29 Okrent, A. M., \& Alston, J. M. (2011). "Demand for food in the United States: A review of literature, evaluation of previous estimates, and presentation of new estimates of demand." Giannini Foundation of Agricultural Economics, University of California.
} 
in the estimations, the own-price elasticity estimates became problematic, so loins were ultimately dropped from the equations assuming multi-collinearity between loin and the other cut price was creating estimation issues. 
Table 4. Pork Primal Per Capita Disappearance Estimate Equations:

$\ln ($ Dependent Variable $)=\ln ($ Disappearance/Capita of Pork Primal Cut $)$

\begin{tabular}{|c|c|c|c|c|c|c|}
\hline Variable & Belly & Butt & Ham & Loin & Picnic & Rib \\
\hline Intercept & $\begin{array}{c}1.604 * * * \\
(<0.01)\end{array}$ & $\begin{array}{c}0.422 * \\
(0.09)\end{array}$ & $\begin{array}{c}1.390 * * * \\
(<0.01)\end{array}$ & $\begin{array}{l}0.334 \\
(0.24)\end{array}$ & $\begin{array}{l}0.205 \\
(0.48)\end{array}$ & $\begin{array}{l}-0.134 \\
(0.75)\end{array}$ \\
\hline $\begin{array}{c}\text { ln(Primal } \\
\text { Cutout } \\
\text { Value/ } \\
\text { CPI) }\end{array}$ & $\begin{array}{c}-0.039^{*} \\
(0.10)\end{array}$ & $\begin{array}{c}-0.175^{* * * *} \\
(<0.01)\end{array}$ & $\begin{array}{c}-0.095 * * * \\
(<0.01)\end{array}$ & $\begin{array}{c}-0.269 * * * \\
(<0.01)\end{array}$ & $\begin{array}{c}-0.140^{* * * *} \\
(<0.01)\end{array}$ & $\begin{array}{c}-0.185^{* * * *} \\
(<0.01)\end{array}$ \\
\hline $\begin{array}{c}\ln (\text { Comp } \\
\text { or Sub } \\
\text { Value/ } \\
\text { CPI })\end{array}$ & $\begin{array}{l}-0.031^{\wedge} \\
(0.33)\end{array}$ & --- & --- & $\begin{array}{l}0.033^{\star} \\
(0.36)\end{array}$ & --- & $\begin{array}{l}0.029^{\prime \prime \prime} \\
(0.49)\end{array}$ \\
\hline $\begin{array}{c}\ln (\text { Per } \\
\text { Capita } \\
\text { Income })\end{array}$ & $\begin{array}{c}0.522 * * * \\
(<0.01)\end{array}$ & $\begin{array}{c}0.372 * * * \\
(<0.01)\end{array}$ & $\begin{array}{c}0.356^{* * * *} \\
(<0.01)\end{array}$ & $\begin{array}{l}0.079 \\
(0.31)\end{array}$ & $\begin{array}{c}0.276^{* * *} \\
(<0.01)\end{array}$ & $\begin{array}{c}0.433 * * * \\
(<0.01)\end{array}$ \\
\hline $\begin{array}{c}\text { Jan } \\
\text { (dummy) }\end{array}$ & $\begin{array}{l}0.029 \\
(0.20)\end{array}$ & $\begin{array}{c}-0.040^{*} \\
(0.07)\end{array}$ & $\begin{array}{c}-0.151^{* * * *} \\
(<0.01)\end{array}$ & $\begin{array}{l}0.007 \\
(0.69)\end{array}$ & $\begin{array}{l}-0.030 \\
(0.20)\end{array}$ & $\begin{array}{l}0.052^{*} \\
(0.09)\end{array}$ \\
\hline $\begin{array}{c}\text { Feb } \\
\text { (dummy) }\end{array}$ & $\begin{array}{c}-0.067 * * * \\
(<0.01)\end{array}$ & $\begin{array}{c}-0.132 * * * \\
(<0.01)\end{array}$ & $\begin{array}{c}-0.202 * * * \\
(<0.01)\end{array}$ & $\begin{array}{c}-0.090^{* * * *} \\
(<0.01)\end{array}$ & $\begin{array}{c}-0.138 * * * \\
(<0.01)\end{array}$ & $\begin{array}{c}-0.087 * * * \\
(<0.01)\end{array}$ \\
\hline $\begin{array}{c}\text { Mar } \\
\text { (dummy) }\end{array}$ & $\begin{array}{l}0.027 \\
(0.23)\end{array}$ & $\begin{array}{l}-0.012 \\
(0.57)\end{array}$ & $\begin{array}{l}-0.029 \\
(0.25)\end{array}$ & $\begin{array}{l}0.012 \\
(0.47)\end{array}$ & $\begin{array}{l}-0.033 \\
(0.15)\end{array}$ & $\begin{array}{c}0.091 * * * \\
(<0.01)\end{array}$ \\
\hline $\begin{array}{c}\text { Apr } \\
\text { (dummy) }\end{array}$ & $\begin{array}{c}-0.065^{* * * *} \\
(<0.01)\end{array}$ & $\begin{array}{c}-0.090^{* * * *} \\
(<0.01)\end{array}$ & $\begin{array}{c}-0.221 * * * \\
(<0.01)\end{array}$ & $\begin{array}{c}-0.061 * * * \\
(<0.01)\end{array}$ & $\begin{array}{c}-0.120^{* * * *} \\
(<0.01)\end{array}$ & $\begin{array}{c}0.087 * * * \\
(<0.01)\end{array}$ \\
\hline $\begin{array}{c}\text { May } \\
\text { (dummy) }\end{array}$ & $\begin{array}{c}-0.069 * * * \\
(<0.01)\end{array}$ & $\begin{array}{c}-0.095^{* * * *} \\
(<0.01)\end{array}$ & $\begin{array}{c}-0.256^{* * * *} \\
(<0.01)\end{array}$ & $\begin{array}{c}-0.052 * * * \\
(-0.01)\end{array}$ & $\begin{array}{c}-0.124 * * * * \\
(<0.01)\end{array}$ & $\begin{array}{c}0.290^{* * * *} \\
(<0.01)\end{array}$ \\
\hline $\begin{array}{c}\text { Jun } \\
\text { (dummy) }\end{array}$ & $\begin{array}{l}-0.022 \\
(0.33)\end{array}$ & $\begin{array}{c}-0.078^{* * *} \\
(<0.01)\end{array}$ & $\begin{array}{c}-0.218^{* * *} \\
(<0.01)\end{array}$ & $\begin{array}{c}-0.040 * * \\
(0.03)\end{array}$ & $\begin{array}{c}-0.103^{* * * *} \\
(<0.01)\end{array}$ & $\begin{array}{c}0.320^{* * * *} \\
(<0.01)\end{array}$ \\
\hline $\begin{array}{c}\text { Jul } \\
\text { (dummy) }\end{array}$ & $\begin{array}{l}-0.028 \\
(0.23)\end{array}$ & $\begin{array}{c}-0.126^{* * * *} \\
(<0.01)\end{array}$ & $\begin{array}{c}-0.227 * * * \\
(<0.01)\end{array}$ & $\begin{array}{c}-0.074 * * * \\
(<0.01)\end{array}$ & $\begin{array}{c}-0.127 * * * * \\
(<0.01)\end{array}$ & $\begin{array}{l}0.046 \\
(0.13)\end{array}$ \\
\hline $\begin{array}{c}\text { Aug } \\
\text { (dummy) }\end{array}$ & $\begin{array}{l}0.042^{*} \\
(0.07)\end{array}$ & $\begin{array}{c}-0.033 \\
(0.13)\end{array}$ & $\begin{array}{c}-0.146 * * * \\
(<0.01)\end{array}$ & $\begin{array}{l}0.002 \\
(0.93)\end{array}$ & $\begin{array}{c}-0.046^{* * *} \\
(0.04)\end{array}$ & $\begin{array}{c}0.154 * * * \\
(<0.01)\end{array}$ \\
\hline $\begin{array}{c}\text { Sep } \\
\text { (dummy) }\end{array}$ & $\begin{array}{l}-0.002 \\
(0.92)\end{array}$ & $\begin{array}{c}-0.051^{* *} \\
(0.03)\end{array}$ & $\begin{array}{c}-0.141 * * * \\
(<0.01)\end{array}$ & $\begin{array}{l}-0.027 \\
(0.13)\end{array}$ & $\begin{array}{c}-0.059^{* *} \\
(0.01)\end{array}$ & $\begin{array}{l}-0.041 \\
(0.19)\end{array}$ \\
\hline $\begin{array}{c}\text { Oct } \\
\text { (dummy) }\end{array}$ & $\begin{array}{c}0.078^{* * * *} \\
(<0.01)\end{array}$ & $\begin{array}{l}-0.036 \\
(0.11)\end{array}$ & $\begin{array}{c}0.070 * * * \\
(<0.01)\end{array}$ & $\begin{array}{c}0.064 * * * \\
(<0.01)\end{array}$ & $\begin{array}{c}.057^{* * *} \\
(0.01)\end{array}$ & $\begin{array}{l}0.003 \\
(0.91)\end{array}$ \\
\hline $\begin{array}{c}\text { Nov } \\
\text { (dummy) }\end{array}$ & $\begin{array}{l}0.003 \\
(0.90)\end{array}$ & $\begin{array}{l}-0.027 \\
(0.23)\end{array}$ & $\begin{array}{c}0.096 * * * * \\
(<0.01)\end{array}$ & $\begin{array}{l}-0.025 \\
(0.14)\end{array}$ & $\begin{array}{l}0.001 \\
(0.99)\end{array}$ & $\begin{array}{l}-0.033 \\
(0.29)\end{array}$ \\
\hline $\mathrm{R}^{2}$ & 0.60 & 0.68 & 0.83 & 0.82 & 0.70 & 0.79 \\
\hline $\begin{array}{l}\text { Durbin- } \\
\text { Watson }\end{array}$ & 2.10 & 2.23 & 2.03 & 2.60 & 2.09 & 2.26 \\
\hline
\end{tabular}

${ }^{\wedge}$ Complement: Ground Beef 90

- Substitute: Beef Tenderloin

"' Substitute: Beef Shortribs

Single, double, and triple asterisks $\left(^{*}\right)$ denote statistical significance of the coefficients at the $10 \%, 5 \%$, and $1 \%$ levels, respectively. Numbers in parentheses are p-values. 
As shown in Table 4, own-price elasticities for each cut are statistically significant at the $10^{\text {th }}$ percentile or less. Bellies are the most inelastic with an own-price elasticity of -0.039 . Loins are the most elastic with an own-price elasticity of -0.762 . By aggregating the own-price elasticities of each of the cuts, weighing each elasticity by carcass yields outlined in Table 2, one can derive a monthly own-price elasticity for the pork cutout of -0.139 . While this elasticity is more inelastic than those outlined in the review of the literature, it is important to note that because this is a monthly elasticity it will inherently be more inelastic than annual results.

Income elasticities for each primal cut are statistically significant at the 1 percent level except for loins. Bellies have the highest income elasticity at 0.522 ; loins have the lowest at 0.079 . Aggregating the income elasticities by again weighing each by the carcass yields in Table 2, an aggregate monthly income elasticity for the pork cutout of 0.282 is derived. This suggests that pork is a normal good, which is consistent with the literature. Cross-price elasticities are calculated for the belly, loin, and rib cuts. The cross-price elasticity of bellies with respect to ground beef is -0.031 . This suggests that ground beef is a complement to pork bellies. This alludes to the popular bacon cheeseburger pairing mentioned in the introduction. The cross-price elasticity of pork loins with respect to beef tenderloins is 0.033 , which suggests the two are substitutes. Finally, the cross-price elasticity of ribs with respect to beef short ribs is 0.029 , which suggests that they are substitutes, as well.

January through November monthly dummy variables are included to account for the seasonality of demand for the cuts. Hams, for example, typically see demand spikes in March, in preparation for the Easter holiday, and in October and November leading up to 
Thanksgiving and Christmas holidays. Figure 5 illustrates how consumers increase consumption around these times. Similarly, ribs usually experience an increase in demand in May and June in preparation for the summer grilling months as can be seen in Figure 6.

\section{Figure 7. Monthly Ham Disappearance}

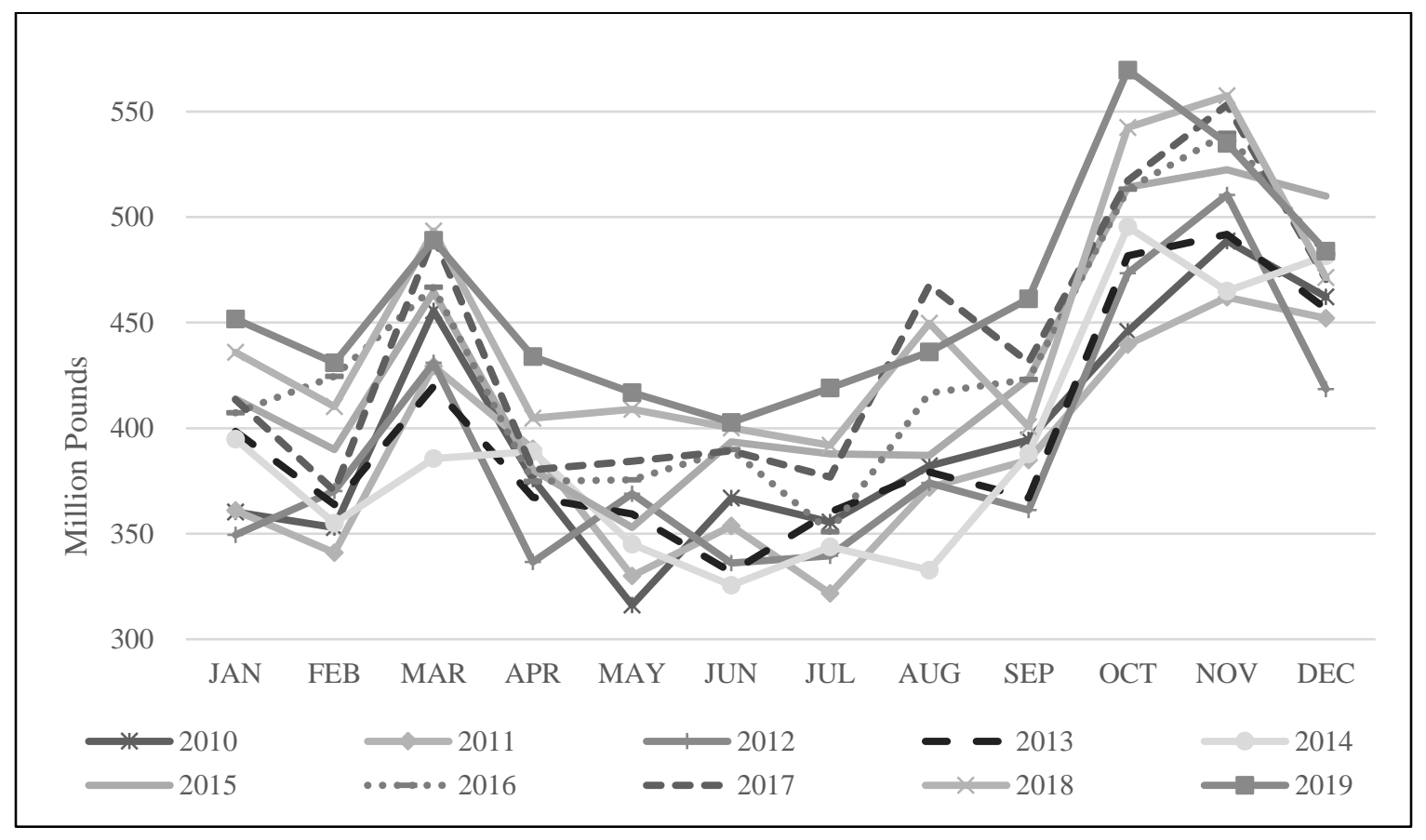




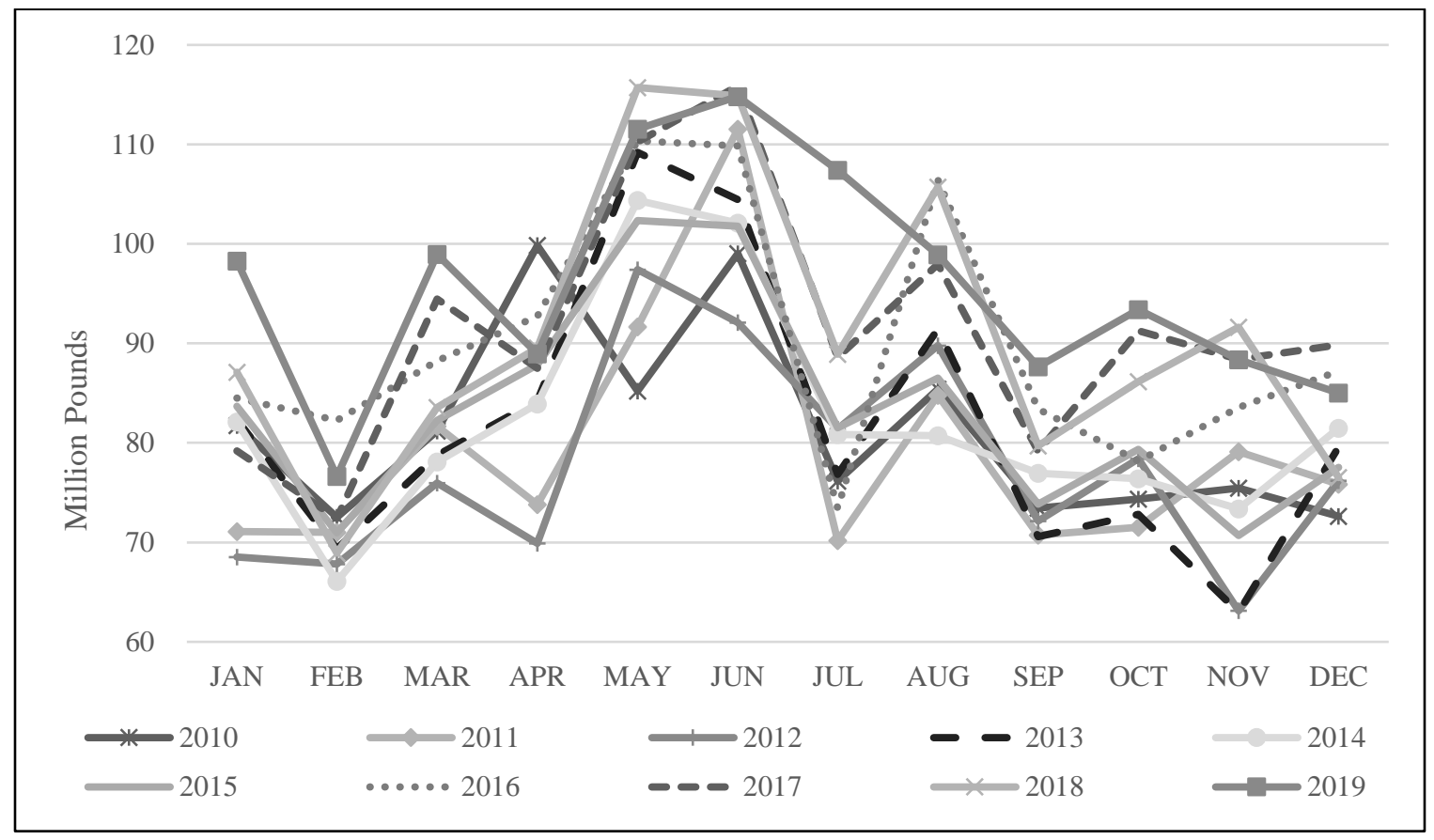

The $\mathrm{R}^{2}$ of an equation quantifies how much lower the sum of squared residuals is compared to the total sum of squares. An $\mathrm{R}^{2}$ of one means the equation has a perfect linear fit. On the other hand, an $\mathrm{R}^{2}$ of zero implies there is no relationship between the dependent and independent variables. ${ }^{30}$ Of the equations summarized in Table 4 , the ham equation has the best fit, with an $\mathrm{R}^{2}$ of 0.83 . The belly equation has the worst fit with an $\mathrm{R}^{2}$ of 0.60 . Figure 7 displays the fit of the butt equation over the period of fit, which spans from January 2010 to August 2020. Figure 8 shows the fit of the butt equation in the four months immediately following the period of fit. As shown, the values predicted by the butt equation closely follow the actual values.

\footnotetext{
${ }^{30}$ Stewart, Brandon. (2016, October 10). “Simple Linear Regression.” [PowerPoint slides]. Princeton University. Available at https://scholar.princeton.edu/sites/default/files/bstewart/files/lecture5slides.pdf [Accessed February 2021.]
} 
Figure 9. Per Capita Butt Disappearance over Period of Fit, Jan 2010 - Aug 2020

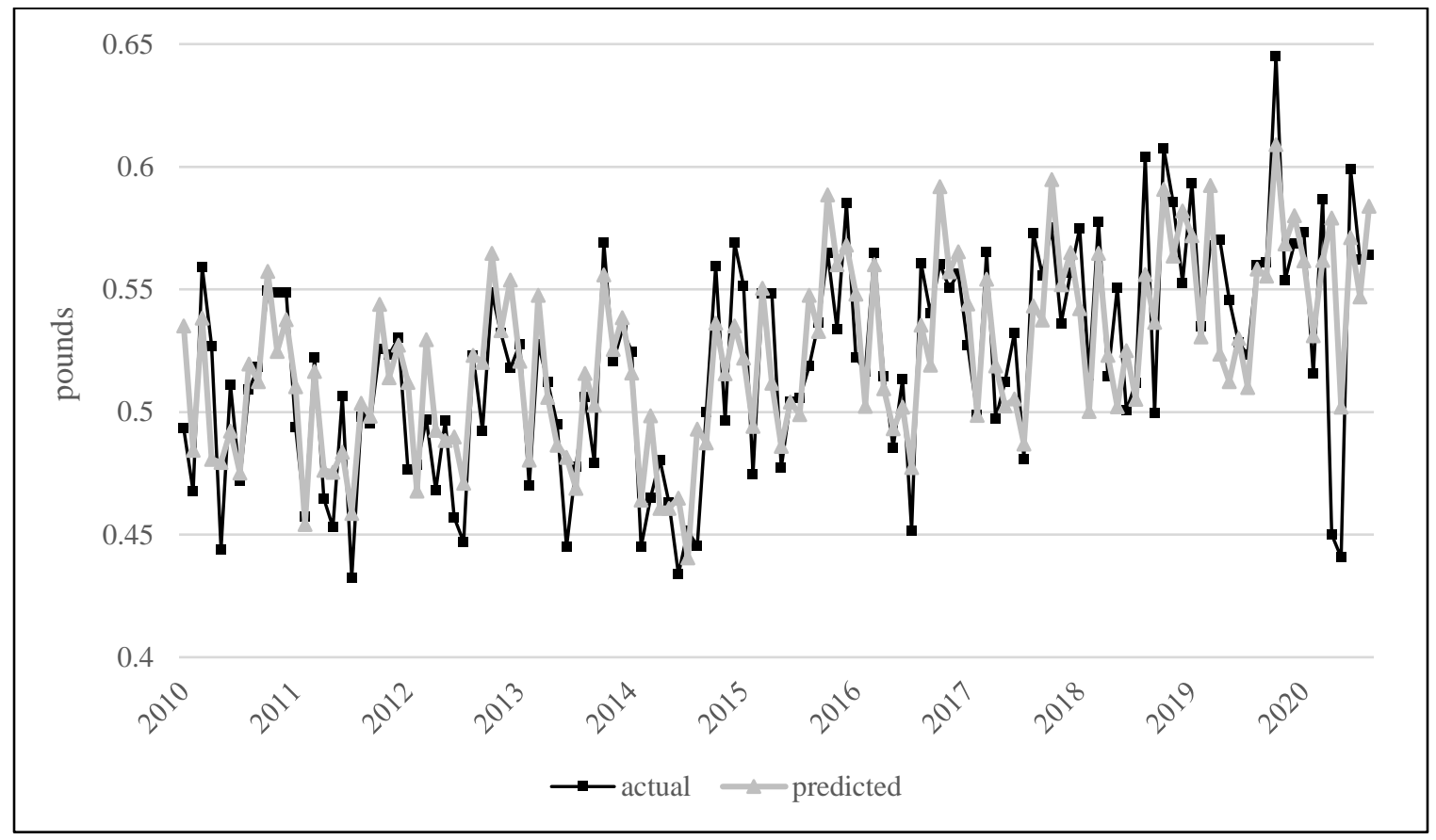

Figure 10. Per Capita Butt Disappearance outside Period of Fit, Sept 2020 - Dec 2020

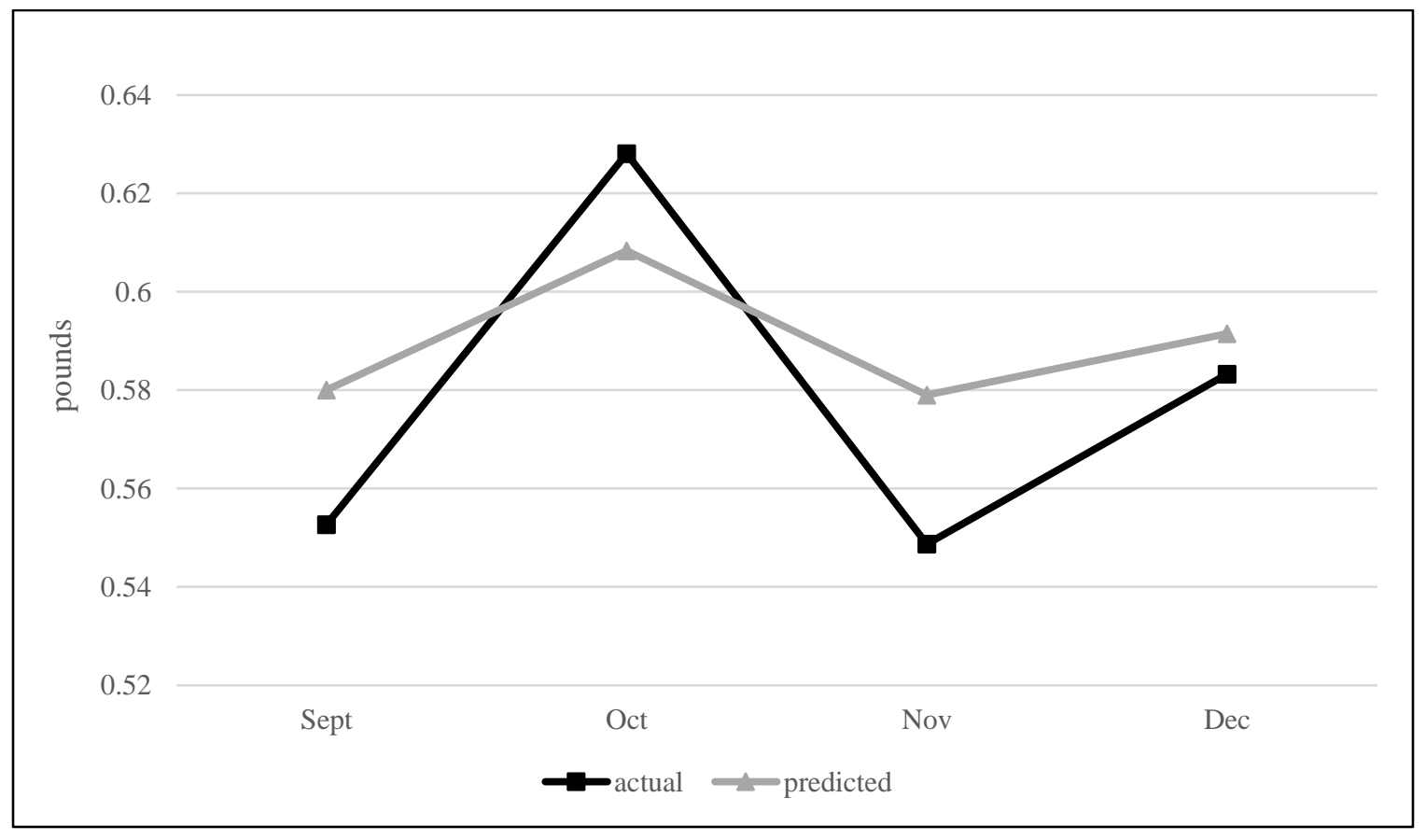

The Durbin-Watson test is used in statistical analysis to detect first-order autocorrelation in the residuals of regressions. The results of the test determine whether the error term in 
one period is positively or negatively correlated with the error term in the previous period. Durbin-Watson test statistics range from 0 to 4 . A value of 2 indicates no autocorrelation. Values less than 2 indicate positive autocorrelation; values greater than 2 indicate negative autocorrelation. ${ }^{31}$ As outlined in Table 4, the equations' Durbin-Watson test statistics are all near 2 or slightly greater, which means they are all within an acceptable range of little to no autocorrelation.

Using the estimated parameters outlined in this chapter, an economic model of the pork industry was created to estimate the implications that various scenarios could have on the U.S. pork cutout value. This model and the scenarios are explained in the next chapter.

${ }^{31}$ Pennsylvania State University Department of Statistics. "Testing and Remedial Measures for Autocorrelation." Accessed Feb 2021. Available at https://online.stat.psu.edu/stat501/lesson/14/14.3. 


\section{Chapter 5: Scenarios}

The demand equations estimated in chapter 4 do not represent the full structure of the pork industry. To run shocks that show the overall industry effects of changing exports requires a more complete system. To simulate system wide effects, this research mimics other research efforts to have a full U.S. pork industry system. This scenario analysis exogenously considers competing meat markets like beef and chicken and feed markets and only estimates reduced form export equations for countries outside of the U.S.

The production equation used in the model, outlined in Table 5, mimics the equation used in the U.S. livestock model of the Food and Agricultural Policy Research Institute (FAPRI) at the University of Missouri. Individual pork primal cut production numbers were derived by multiplying the total production estimate by the carcass yields outlined in Table 2. 
Table 5. Production Estimate Equation: (Dependent Variable $=$ Pork Production $*)$

\begin{tabular}{|c|c|c|}
\hline \multicolumn{2}{|r|}{ Variable } & Coefficient \\
\hline & Intercept & 75 \\
\hline \multicolumn{2}{|c|}{ Production, $\mathrm{t}-1$} & 0.02 \\
\hline \multicolumn{2}{|c|}{ Production, $\mathrm{t}-8$} & 0.95 \\
\hline \multicolumn{2}{|c|}{ Pork Cutout Value } & 1.4 \\
\hline \multicolumn{2}{|r|}{ Feed Cost ${ }^{+}$} & -0.4 \\
\hline \multirow{12}{*}{ 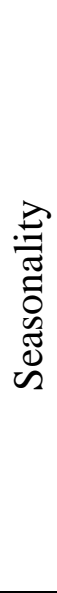 } & Jan & 225 \\
\hline & Feb & 75 \\
\hline & Mar & 300 \\
\hline & Apr & 15 \\
\hline & May & 15 \\
\hline & Jun & -265 \\
\hline & Jul & -225 \\
\hline & Aug & -50 \\
\hline & Sep & -75 \\
\hline & Oct & 325 \\
\hline & Nov & 75 \\
\hline & Dec & 200 \\
\hline
\end{tabular}

* Production estimated in million pounds

$(\mathrm{t})$ : current period

${ }^{+}$Feed cost $=(80 \% *$ corn price $)+(20 \% *$ soybean meal price $)$

Export equations for each primal cut were estimated for Canada, China, Japan, and South

Korea. The remaining countries were amalgamated into the rest of the world (ROW), and an export elasticity of -0.8 was used. This elasticity was chosen based on existing research and was, similar to the production equation, adapted from the MU FAPRI model.

The model is used to construct a baseline case that estimates values for the endogenous model variables based on assumptions about the remaining exogenous variables used in the system. Baseline values begin in September 2020 and follow through December 2025. The following shocks were enacted from January 2021 through December 2025, with January 2021 through December 2021 representing the short run, January 2022 through December 2024 representing the medium run, and January 2025 through 
December 2025 representing the longer run. In each scenario, values of the endogenous variables determined by the model are compared to the corresponding baseline values to determine the impacts of the scenario.

\section{Chapter 5.1 Decrease in Belly Exports}

The first scenario run was a 10 percent decrease in belly exports from the baseline values for each month spanning from January 2021 through December 2025. The impacts of this scenario on each cut and pork as a whole are summarized in Table 6. 
Table 6. Impacts of Monthly 10 Percent Decrease in U.S. Belly Exports from Baseline Values, January 2021 - December 2025

\begin{tabular}{|c|c|c|c|}
\hline Belly & $\begin{array}{c}\text { Short Run } \\
\text { Year } 1\end{array}$ & $\begin{array}{c}\text { Medium Run } \\
\text { Years 2-4 }\end{array}$ & $\begin{array}{c}\text { Longer Run } \\
\text { Year } 5\end{array}$ \\
\hline Average $\%$ change in cutout value & -4.88 & -4.67 & -4.79 \\
\hline Average $\%$ change in exports & -2.32 & -3.78 & -4.50 \\
\hline \multicolumn{4}{|l|}{ Butt } \\
\hline Average $\%$ change in cutout value & 0.28 & 0.68 & 0.96 \\
\hline Average $\%$ change in exports & -0.19 & -0.58 & -0.92 \\
\hline \multicolumn{4}{|l|}{ Ham } \\
\hline Average $\%$ change in cutout value & 0.29 & 0.66 & 0.86 \\
\hline Average $\%$ change in exports & -0.25 & -0.81 & -1.36 \\
\hline \multicolumn{4}{|l|}{ Loin } \\
\hline Average $\%$ change in cutout value & 0.26 & 0.66 & 0.93 \\
\hline Average $\%$ change in exports & -0.16 & -0.56 & -0.96 \\
\hline \multicolumn{4}{|l|}{ Picnic } \\
\hline Average $\%$ change in cutout value & 0.30 & 0.69 & 0.92 \\
\hline Average $\%$ change in exports & -0.21 & -0.69 & -1.14 \\
\hline \multicolumn{4}{|l|}{ Rib } \\
\hline Average $\%$ change in cutout value & 0.31 & 0.76 & 1.08 \\
\hline Average $\%$ change in exports & -0.27 & -0.80 & -1.27 \\
\hline \multicolumn{4}{|l|}{ Total } \\
\hline Average $\%$ change in cutout value & -1.45 & -0.99 & -0.65 \\
\hline Average $\%$ change in exports & -0.43 & -1.01 & -1.55 \\
\hline Average $\%$ change in production & -0.08 & -0.23 & -0.34 \\
\hline
\end{tabular}

Note that although a 10 percent decrease was imposed, belly exports did not decrease by a full 10 percent. This demonstrates how the model accounts for the decrease in exports, which results in a decrease in the pork cutout value, which then leads to increases in exports, thus offsetting a portion of the original decrease in exports. Table 6 also shows that decreases in exports of bellies leads to increases in the cutout value of each of the other cuts. Pork producers cannot simply decrease the production of one cut. Decreases in production mean fewer carcasses going to market. If demand for the other cuts does not change, their price increases as a result of the decrease in supply. 
Figure 9 displays the initial decrease in cutout value due to the loss in export demand for bellies. Producers respond to lower prices by decreasing production, which eventually leads to increases in the cutout value.

Figure 11. Percentage Change in Pork Cutout Value and Production as Result of Monthly 10 Percent Decrease in U.S. Belly Exports from Baseline Values, Jan 2021 Dec 2025

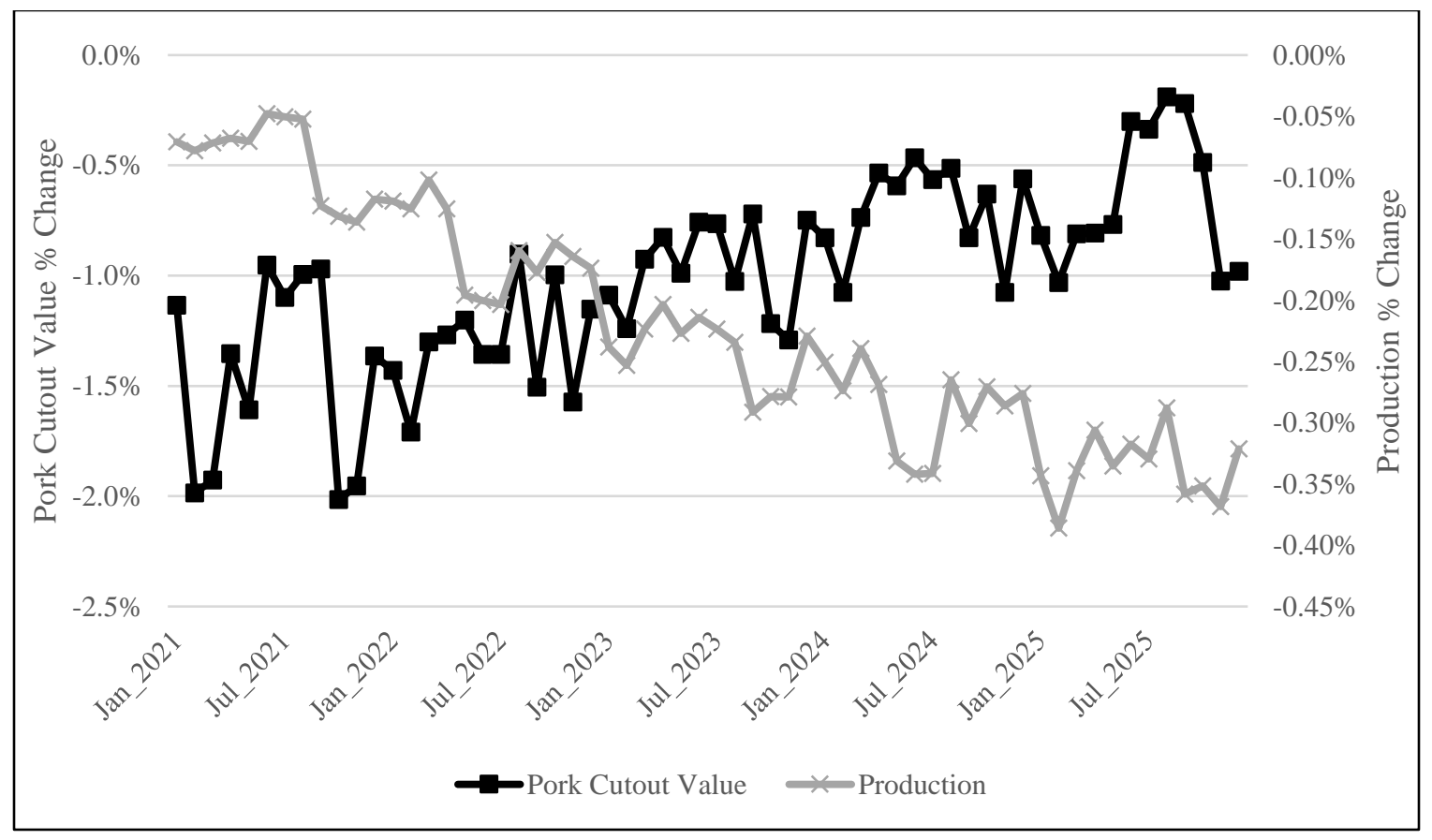


Furthermore, decreasing belly exports similarly decreases exports of the other cuts but to a lesser extent. As explained above, producers will pull back production which increases cutout values. In turn, less of each of the cuts will be exported. This is shown in Figure 10.

Figure 12. Percentage Change in Exports as Result of Monthly 10 Percent Decrease in U.S. Belly Exports from Baseline Values, Jan 2021 - Dec 2025

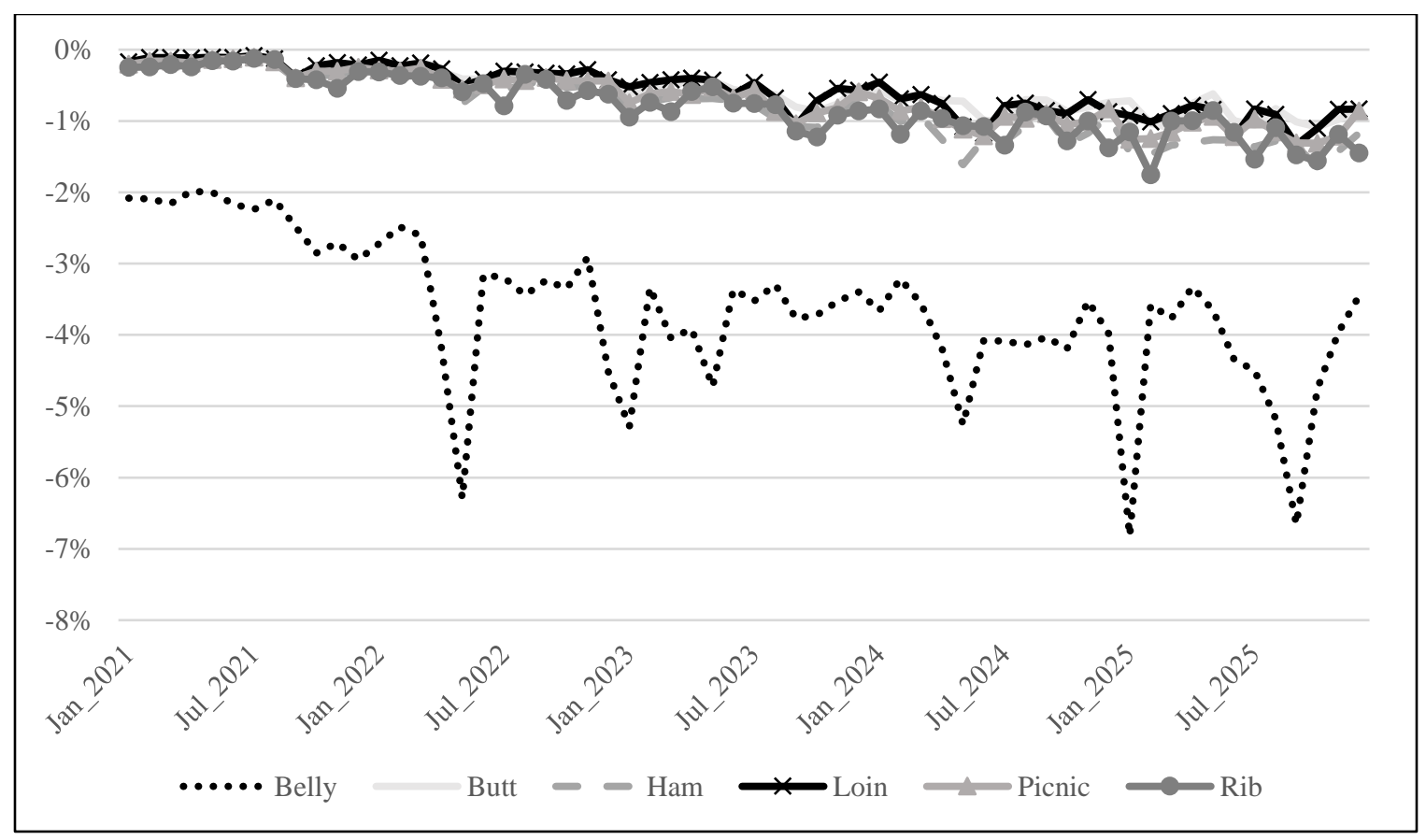


Finally, consider domestic disappearance. As shown in Figure 11, domestic disappearance of bellies increases while disappearance of each of the other cuts decreases.

Figure 11. Percentage Change in Domestic Disappearance as Result of Monthly 10 Percent Decrease in U.S. Belly Exports from Baseline Values, Jan 2021 - Dec 2025

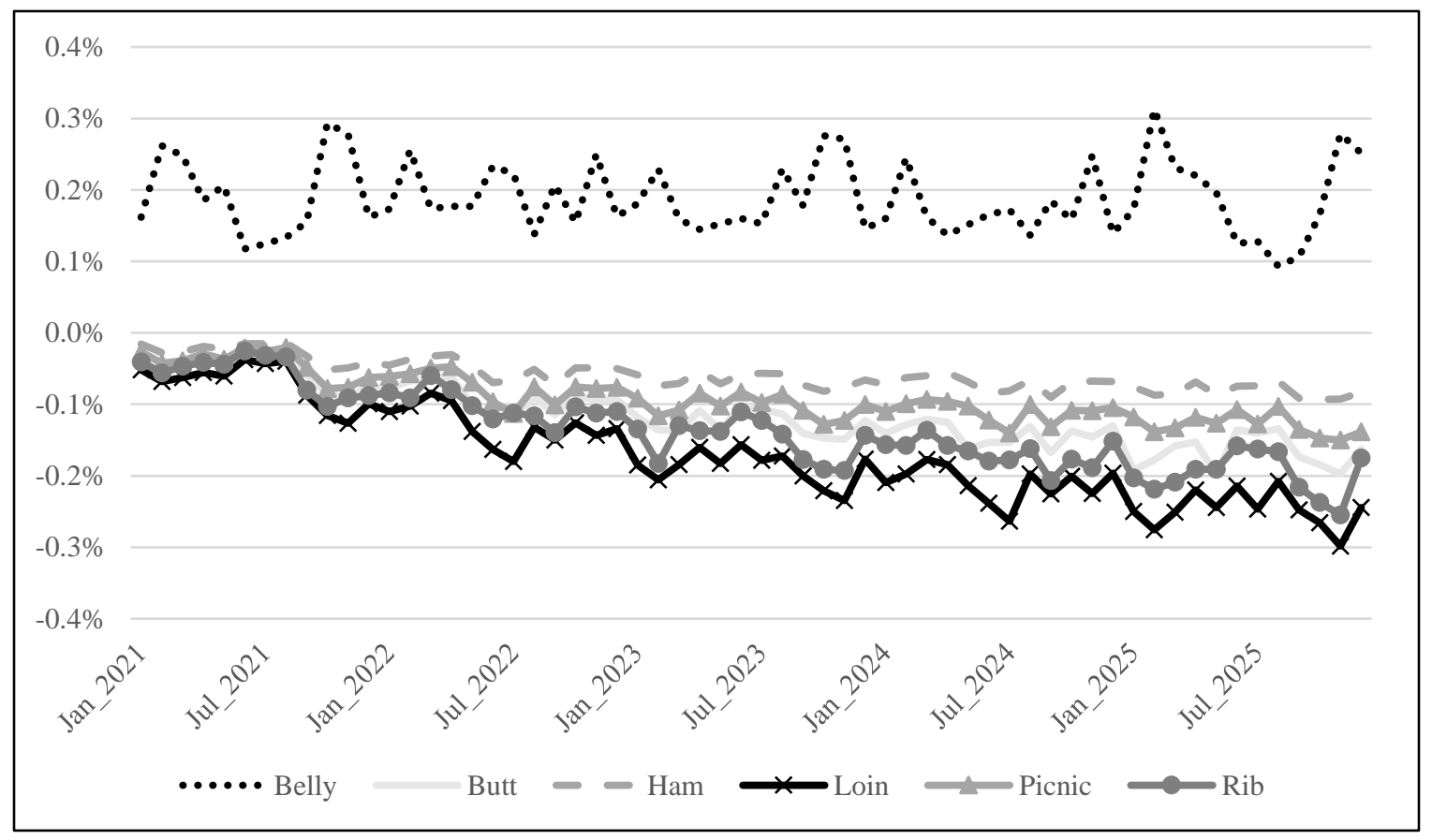




\section{Chapter 5.2 Decrease in Butt Exports}

Similarly, a 10 percent decrease in butt exports from the baseline values for each month spanning from January 2021 through December 2025 was run. The impacts of this scenario on each cut and pork as a whole are summarized in Table 7.

Table 7. Impacts of Monthly 10 Percent Decrease in U.S. Butt Exports from Baseline Values, January 2021 - December 2025

\begin{tabular}{|c|c|c|c|}
\hline & Short Run & Medium Run & Longer Run \\
\hline Belly & & & \\
\hline Average $\%$ change in cutout value & 0.15 & 0.39 & 0.59 \\
\hline Average $\%$ change in exports & -0.31 & -0.90 & -1.30 \\
\hline \multicolumn{4}{|l|}{ Butt } \\
\hline Average $\%$ change in cutout value & -6.89 & -6.34 & -6.04 \\
\hline Average $\%$ change in exports & -4.11 & -4.24 & -4.53 \\
\hline \multicolumn{4}{|l|}{ Ham } \\
\hline Average $\%$ change in cutout value & -0.03 & 0.08 & 0.17 \\
\hline Average $\%$ change in exports & -0.16 & -0.46 & -0.75 \\
\hline \multicolumn{4}{|l|}{ Loin } \\
\hline Average $\%$ change in cutout value & -0.07 & 0.02 & 0.12 \\
\hline Average $\%$ change in exports & -0.39 & -0.80 & -1.10 \\
\hline \multicolumn{4}{|l|}{ Picnic } \\
\hline Average $\%$ change in cutout value & 0.08 & 0.23 & 0.34 \\
\hline Average $\%$ change in exports & -0.12 & -0.37 & -0.60 \\
\hline \multicolumn{4}{|l|}{ Rib } \\
\hline Average $\%$ change in cutout value & 0.10 & 0.29 & 0.42 \\
\hline Average $\%$ change in exports & -0.17 & -0.48 & -0.73 \\
\hline \multicolumn{4}{|l|}{ Total } \\
\hline Average $\%$ change in cutout value & -0.67 & -0.47 & -0.34 \\
\hline Average $\%$ change in exports & -0.77 & -1.12 & -1.43 \\
\hline Average $\%$ change in production & -0.04 & -0.11 & -0.16 \\
\hline
\end{tabular}

Again, note that the 10 percent decrease in butt exports did not result in butt exports decreasing by a full 10 percent. However, the percentage decrease in butt exports, about 4 to 5 percent, is closer to the 10 percent than the 2 to 4 percent decrease in belly exports in the belly scenario. Because bellies are more inelastic than butts, changes in belly prices have less of an impact on the quantity of bellies demanded than that of butts. 
Figure 12 displays the initial decrease in cutout value due to the loss in export demand for butts and the response by producers to scale back pork production.

Figure 12. Percentage Change in Pork Cutout Value and Production as Result of Monthly 10 Percent Decrease in U.S. Butt Exports from Baseline Values, Jan 2021 - Dec 2025

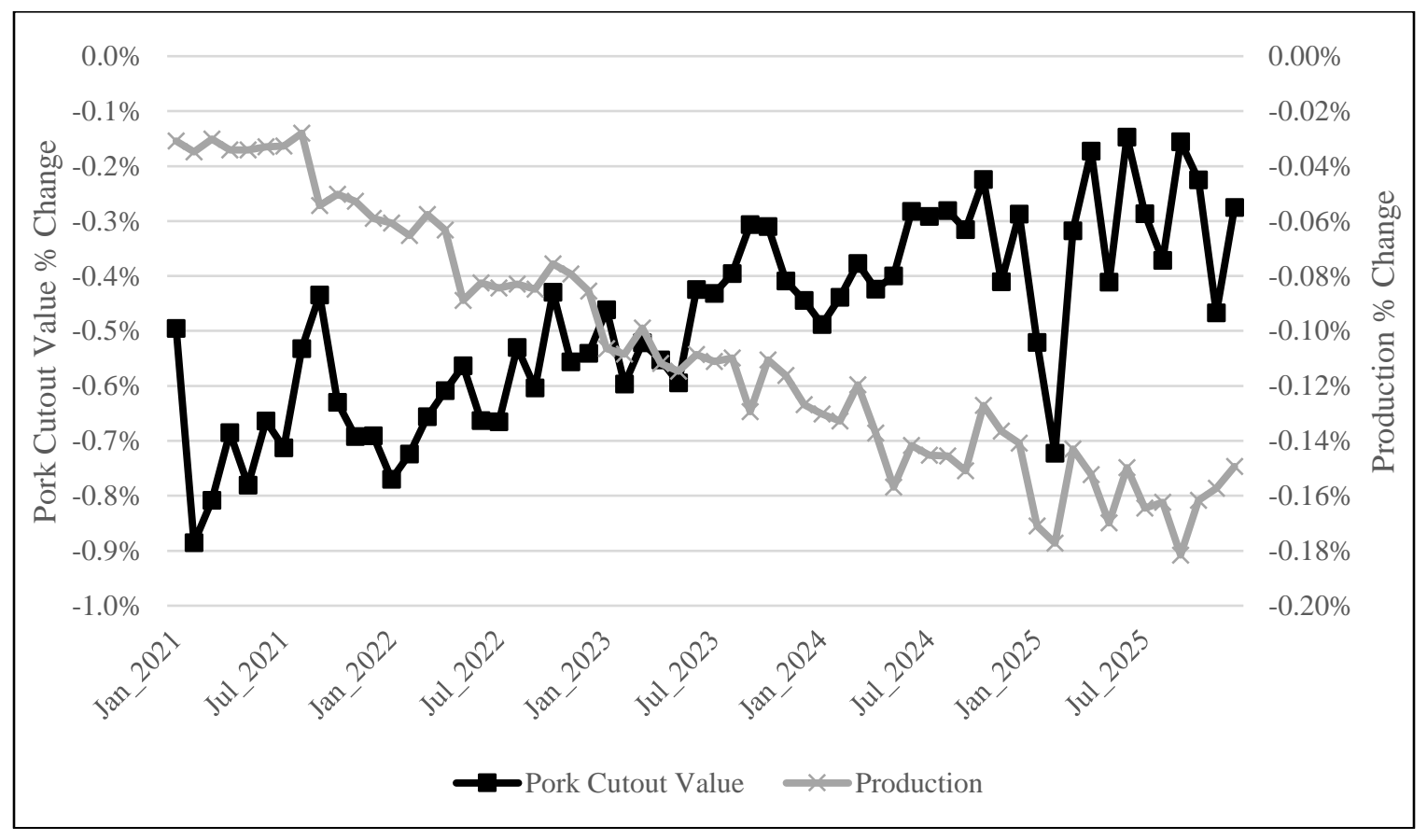


Decreasing butt exports similarly decreases exports of the other cuts but to a lesser extent as shown in Figure 13.

Figure 13. Percentage Change in Exports as Result of Monthly 10 Percent Decrease in U.S. Butt Exports from Baseline Values, Jan 2021 - Dec 2025

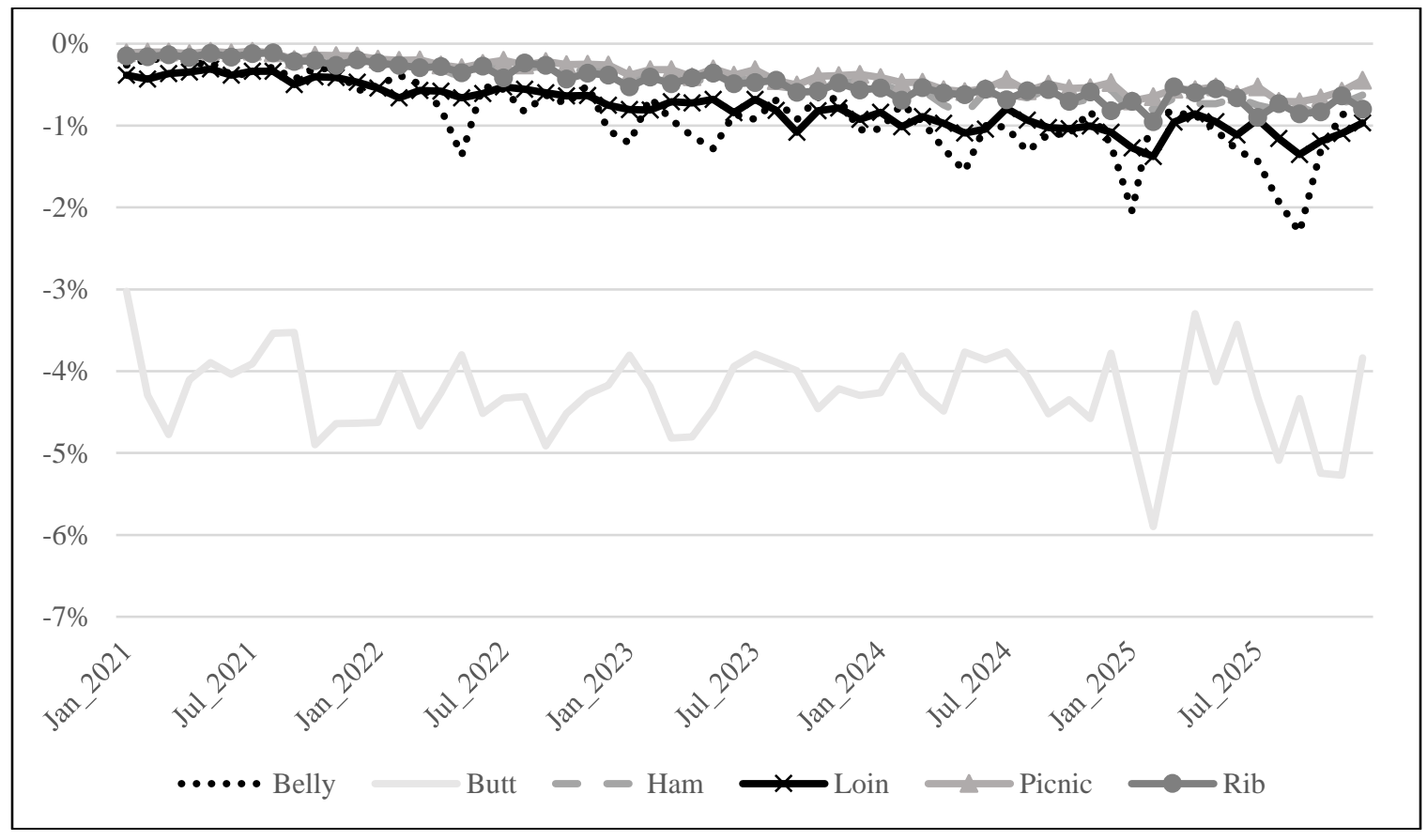


While domestic disappearance of butts increases due to the decrease in prices caused by the decrease in export demand, disappearance of the other cuts remains largely unchanged as shown in Figure 14.

Figure 14. Percentage Change in Domestic Disappearance as Result of Monthly 10 Percent Decrease in U.S. Butt Exports from Baseline Values, Jan 2021 - Dec 2025

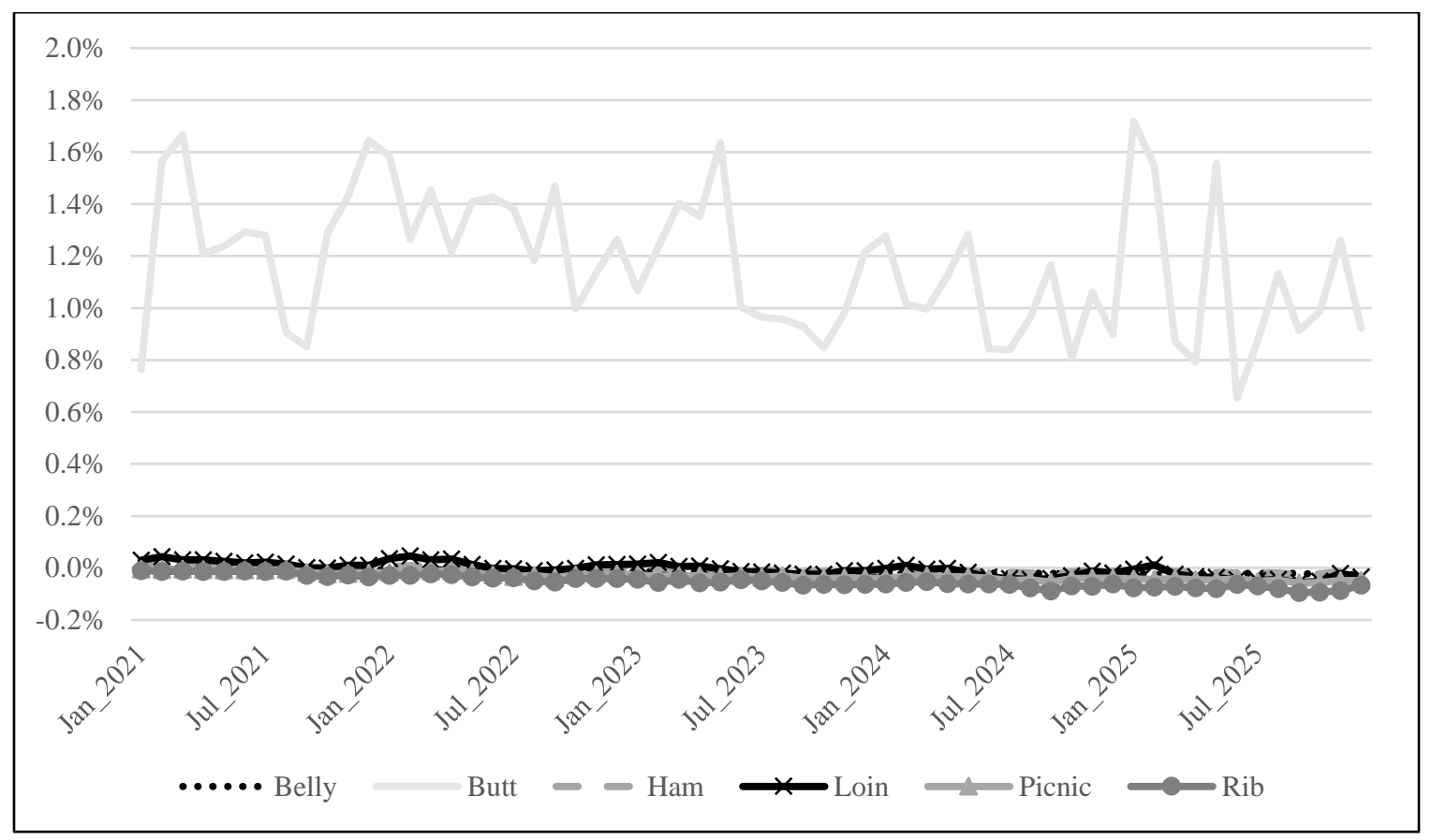




\section{Chapter 5.3 Decrease in Ham Exports}

The impacts of a 10 percent decrease in ham exports from the baseline values for each

month spanning from January 2021 through December 2025 are summarized in Table 8 .

Table 8. Impacts of Monthly 10 Percent Decrease in U.S. Ham Exports from Baseline Values, January 2021 - December 2025

\begin{tabular}{|c|c|c|c|}
\hline & $\begin{array}{l}\text { Short Run } \\
\text { Year } 1\end{array}$ & $\begin{array}{c}\text { Medium Run } \\
\text { Years 2-4 }\end{array}$ & $\begin{array}{c}\text { Longer Run } \\
\text { Year } 5\end{array}$ \\
\hline Belly & & & \\
\hline Average $\%$ change in cutout value & 0.28 & 0.71 & 1.00 \\
\hline Average $\%$ change in exports & -0.56 & -1.56 & -2.06 \\
\hline \multicolumn{4}{|l|}{ Butt } \\
\hline Average $\%$ change in cutout value & 0.23 & 0.57 & 0.75 \\
\hline Average $\%$ change in exports & -0.16 & -0.48 & -0.72 \\
\hline \multicolumn{4}{|l|}{ Ham } \\
\hline Average $\%$ change in cutout value & -7.63 & -6.73 & -5.19 \\
\hline Average $\%$ change in exports & -2.54 & -3.16 & -3.51 \\
\hline \multicolumn{4}{|l|}{$\overline{\text { Loin }}$} \\
\hline Average $\%$ change in cutout value & 0.17 & 0.48 & 0.66 \\
\hline Average $\%$ change in exports & -0.22 & -0.58 & -0.88 \\
\hline \multicolumn{4}{|l|}{ Picnic } \\
\hline Average $\%$ change in cutout value & 0.25 & 0.57 & 0.72 \\
\hline Average $\%$ change in exports & -0.17 & -0.57 & -0.89 \\
\hline \multicolumn{4}{|l|}{ Rib } \\
\hline Average $\%$ change in cutout value & 0.23 & 0.60 & 0.80 \\
\hline Average $\%$ change in exports & -0.25 & -0.71 & -1.04 \\
\hline \multicolumn{4}{|l|}{ Total } \\
\hline Average $\%$ change in cutout value & -1.21 & -0.81 & -0.44 \\
\hline Average $\%$ change in exports & -1.06 & -1.55 & -1.84 \\
\hline Average $\%$ change in production & -0.07 & -0.19 & -0.26 \\
\hline
\end{tabular}


Figure 15 displays the initial decrease in cutout value due to the loss in export demand for hams and the response by producers to scale back pork production as prices decrease.

Figure 15. Percentage Change in Pork Cutout Value and Production as Result of Monthly 10 Percent Decrease in U.S. Ham Exports from Baseline Values, Jan 2021 Dec 2025

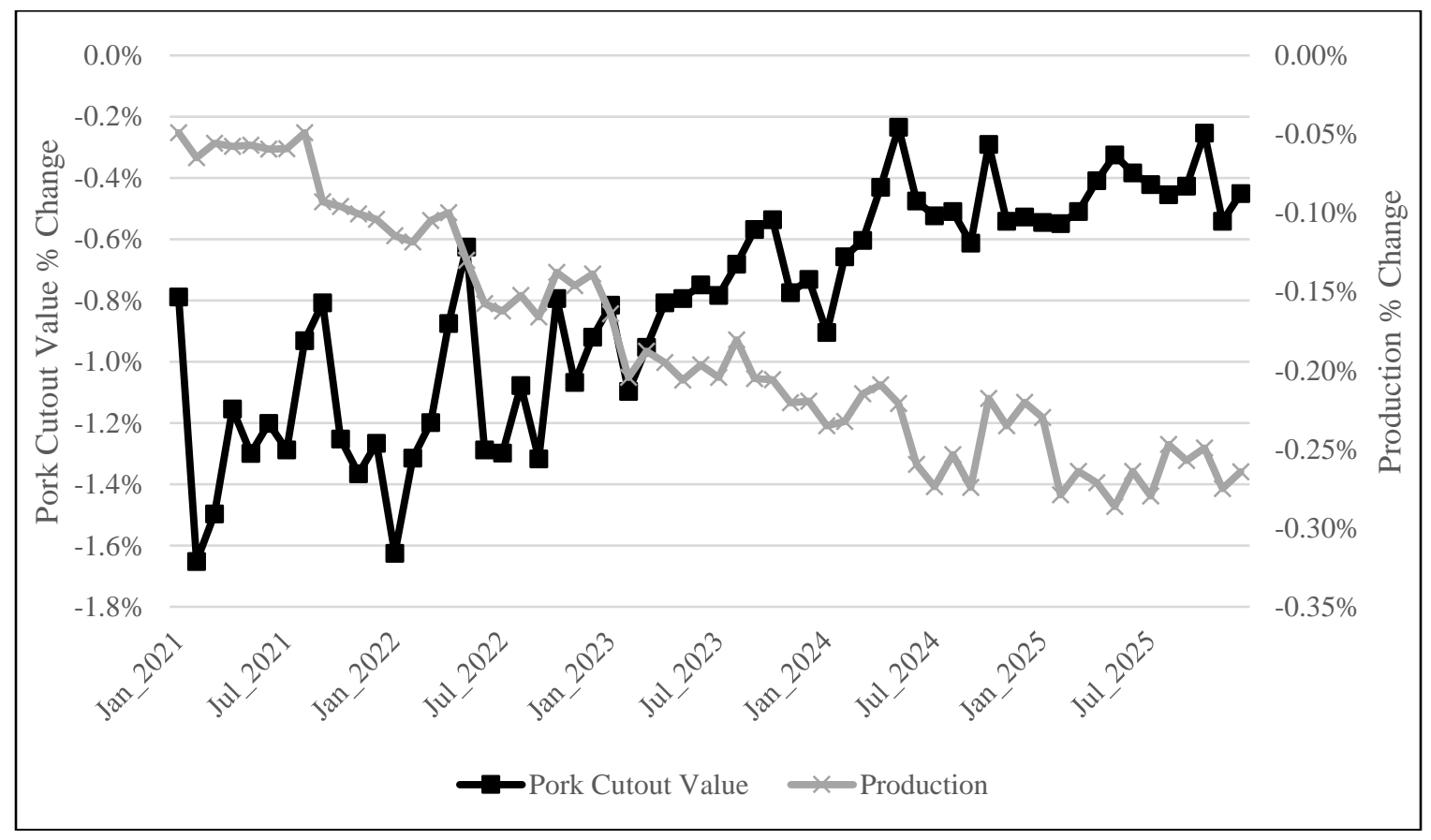


Decreasing ham exports decreases exports of the other cuts, as well, as shown in Figure 16. Most notably, bellies sustain the greatest decrease in exports after hams which is due to strong domestic demand for the cut.

Figure 16. Percentage Change in Exports as Result of Monthly 10 Percent Decrease in U.S. Ham Exports from Baseline Values, Jan 2021 - Dec 2025

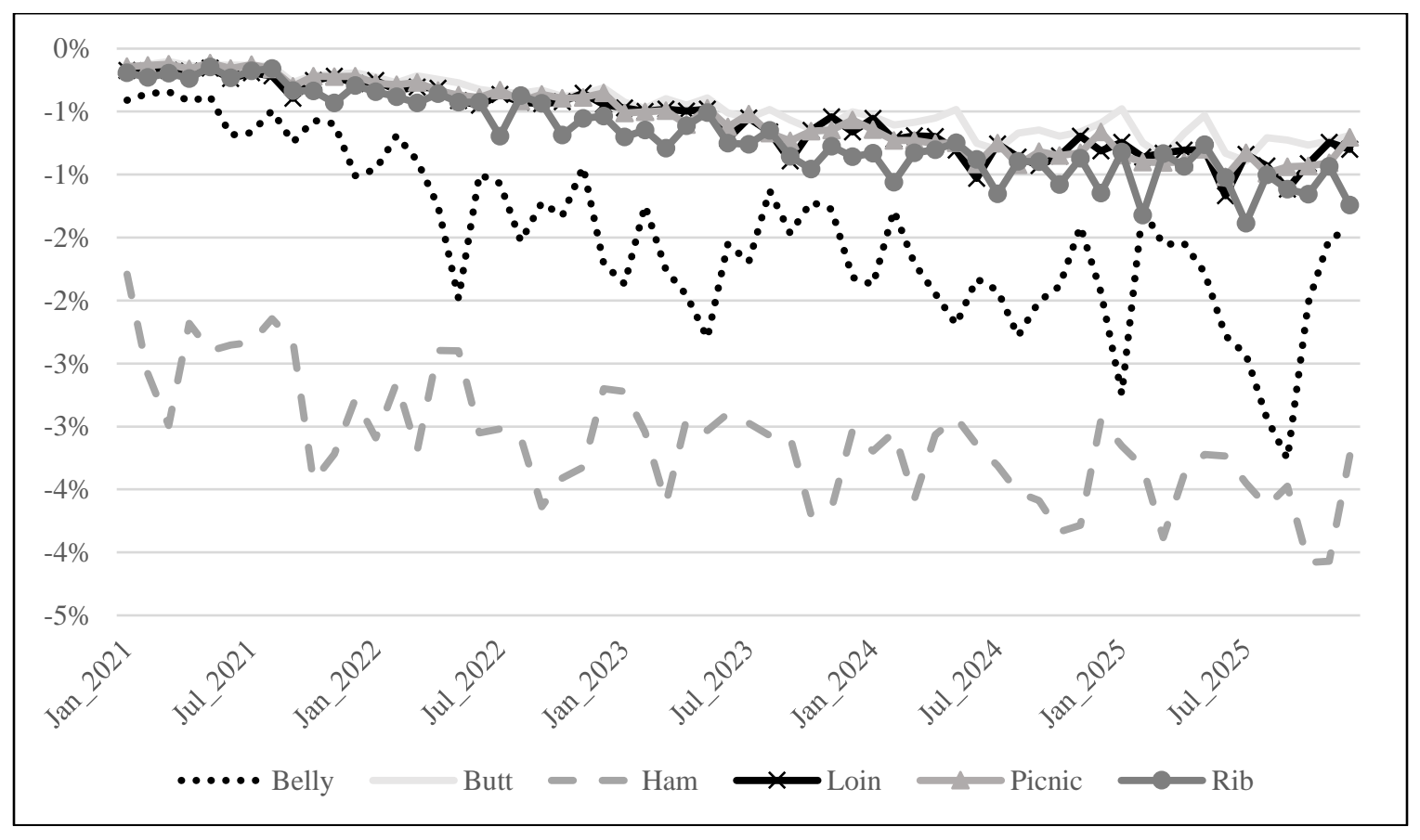


In this scenario, domestic disappearance of hams increases, and disappearance of the other cuts only slightly decreases as shown in Figure 17.

Figure 17. Percentage Change in Domestic Disappearance as Result of Monthly 10 Percent Decrease in U.S. Ham Exports from Baseline Values, Jan 2021 - Dec 2025

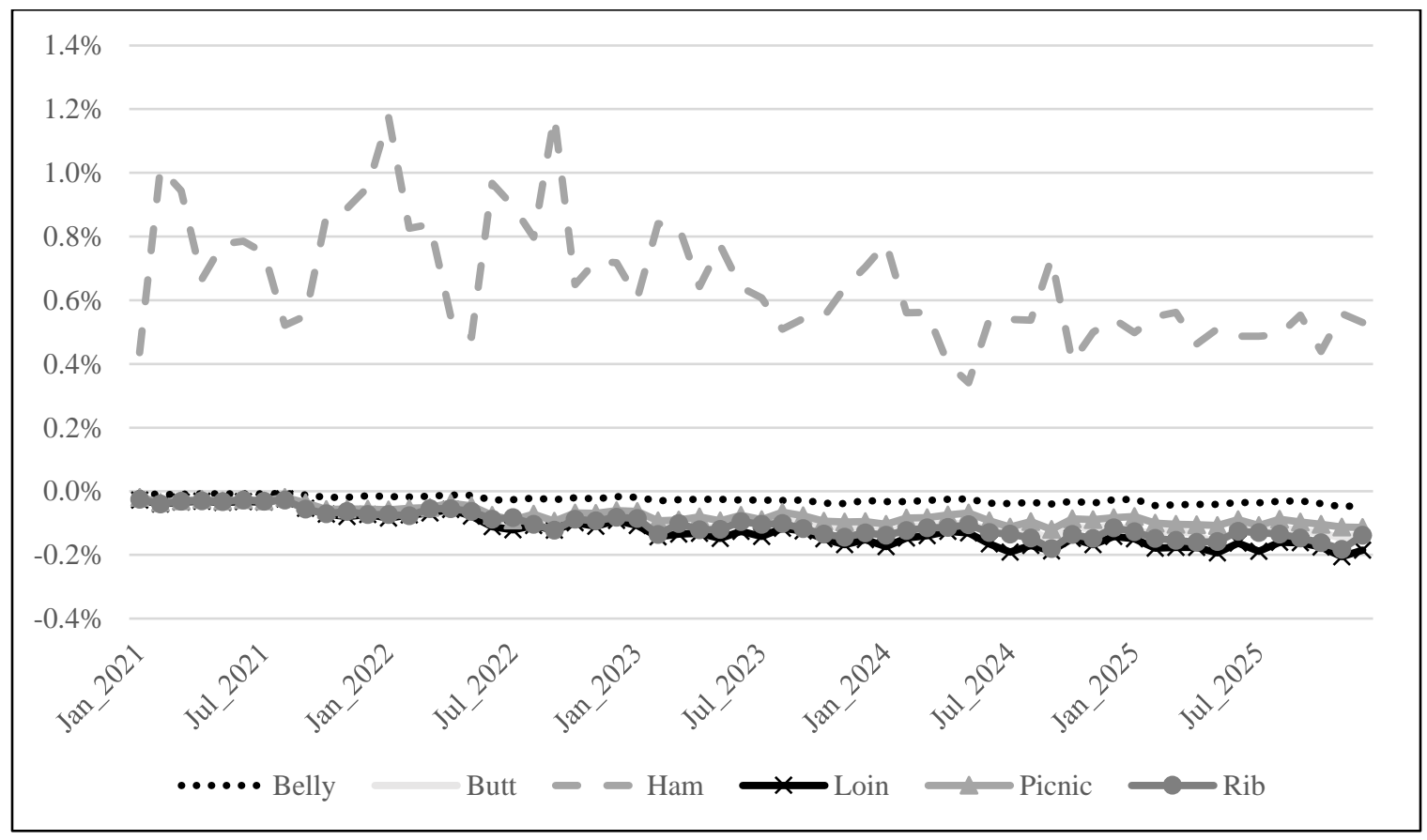




\section{Chapter 5.4 Decrease in Loin Exports}

Table 9 summarizes the impacts of a 10 percent decrease in loin exports from the baseline values for each month spanning from January 2021 through December 2025.

Table 9. Impacts of Monthly 10 Percent Decrease in U.S. Loin Exports from Baseline Values, January 2021 - December 2025

\begin{tabular}{|c|c|c|c|}
\hline Belly & $\begin{array}{c}\text { Short Run } \\
\text { Year } 1\end{array}$ & $\begin{array}{c}\text { Medium Run } \\
\text { Years 2-4 }\end{array}$ & $\begin{array}{c}\text { Longer Run } \\
\text { Year } 5\end{array}$ \\
\hline Average $\%$ change in cutout value & 0.09 & 0.37 & 0.59 \\
\hline Average $\%$ change in exports & -0.45 & -1.20 & -1.63 \\
\hline \multicolumn{4}{|l|}{ Butt } \\
\hline Average $\%$ change in cutout value & 0.17 & 0.41 & 0.56 \\
\hline Average $\%$ change in exports & -0.12 & -0.35 & -0.54 \\
\hline \multicolumn{4}{|l|}{ Ham } \\
\hline Average $\%$ change in cutout value & 0.17 & 0.39 & 0.50 \\
\hline Average $\%$ change in exports & -0.15 & -0.49 & -0.80 \\
\hline \multicolumn{4}{|l|}{ Loin } \\
\hline Average $\%$ change in cutout value & -4.36 & -3.76 & -3.10 \\
\hline Average $\%$ change in exports & -7.51 & -7.87 & -7.97 \\
\hline \multicolumn{4}{|l|}{ Picnic } \\
\hline Average $\%$ change in cutout value & 0.15 & 0.38 & 0.51 \\
\hline Average $\%$ change in exports & -0.15 & -0.43 & -0.69 \\
\hline \multicolumn{4}{|l|}{$\overline{\mathrm{Rib}}$} \\
\hline Average $\%$ change in cutout value & 0.13 & 0.38 & 0.55 \\
\hline Average $\%$ change in exports & -0.23 & -0.59 & -0.86 \\
\hline \multicolumn{4}{|l|}{ Total } \\
\hline Average $\%$ change in cutout value & -0.87 & -0.58 & -0.36 \\
\hline Average $\%$ change in exports & -1.68 & -2.04 & -2.27 \\
\hline Average $\%$ change in production & -0.05 & -0.14 & -0.20 \\
\hline
\end{tabular}

Notice that as loins are the most elastic of the cuts, a 10 percent shock accounts for over a 7 percent decrease in loin exports. Figure 18 displays the percentage changes in cutout value and production caused by the decrease in loin exports. 
Figure 18. Percentage Change in Pork Cutout Value and Production as Result of Monthly 10 Percent Decrease in U.S. Loin Exports from Baseline Values, Jan 2021 Dec 2025

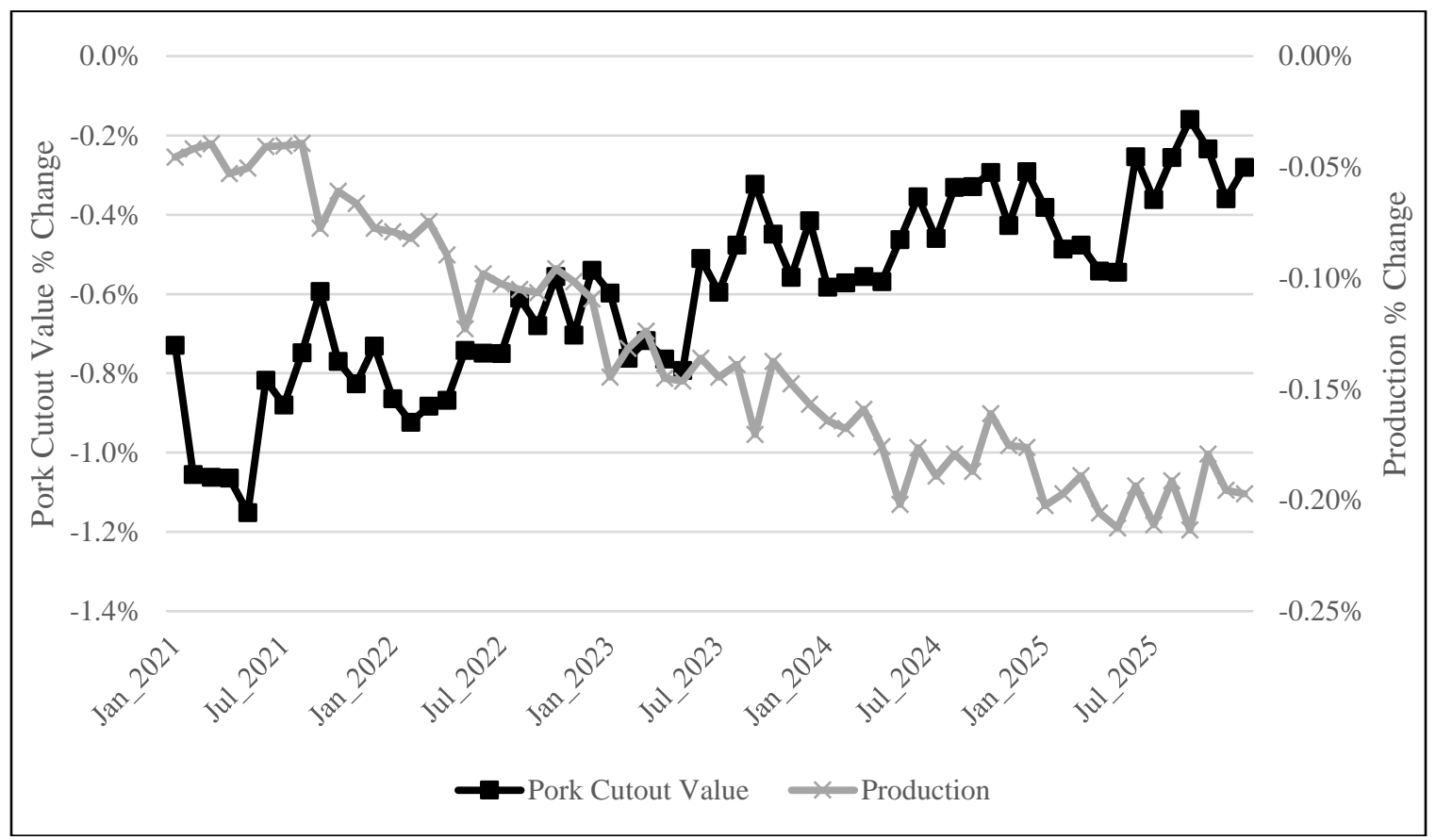


Figure 19 displays the decreases in exports of each of the cuts caused by decreasing the exports of loins.

Figure 19. Percentage Change in Exports as Result of Monthly 10 Percent Decrease in U.S. Loin Exports from Baseline Values, Jan 2021 - Dec 2025

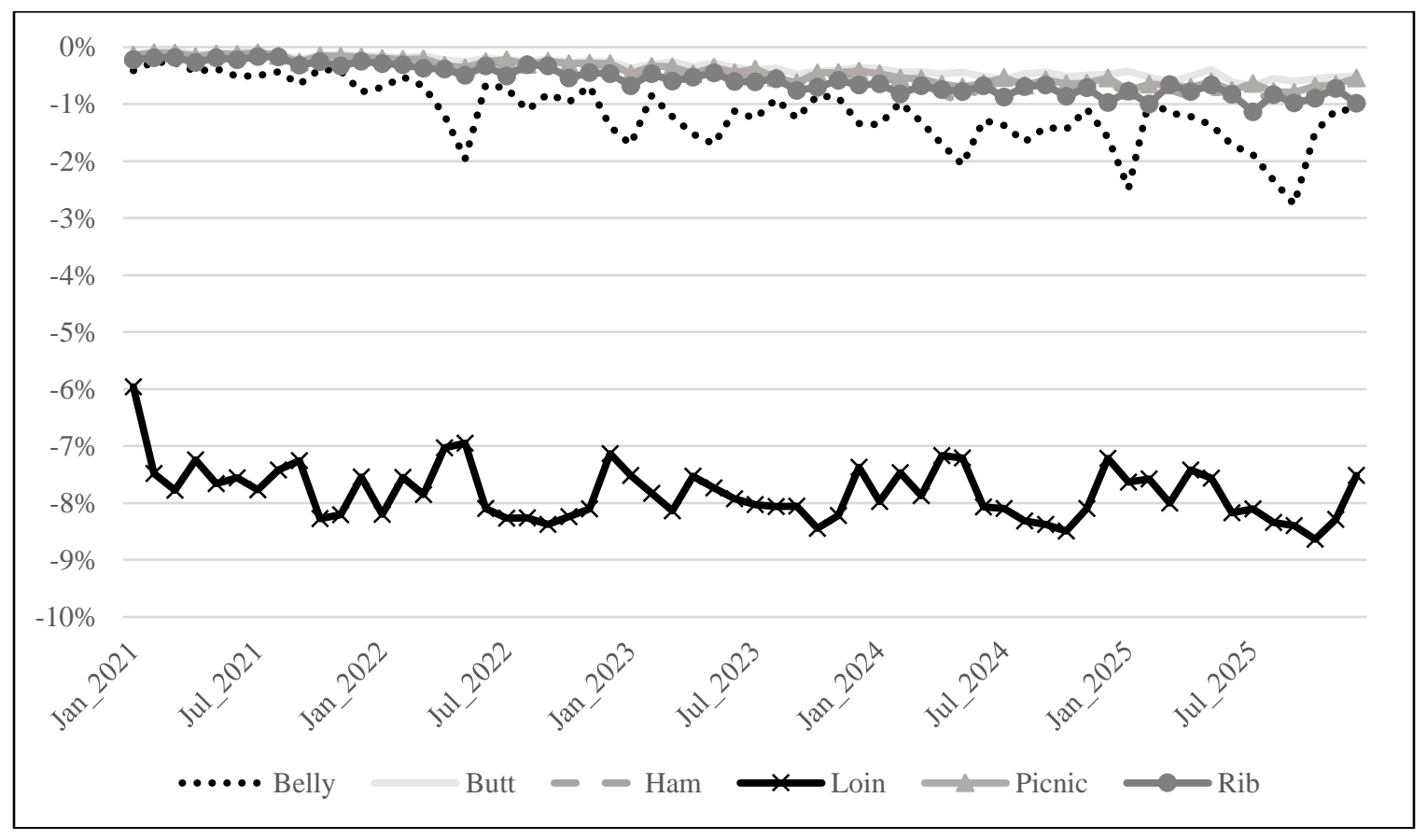


Figure 20 displays that domestic disappearance of loins increases while disappearance of the other cuts is essentially unchanged.

Figure 20. Percentage Change in Domestic Disappearance as Result of Monthly 10 Percent Decrease in U.S. Loin Exports from Baseline Values, Jan 2021 - Dec 2025

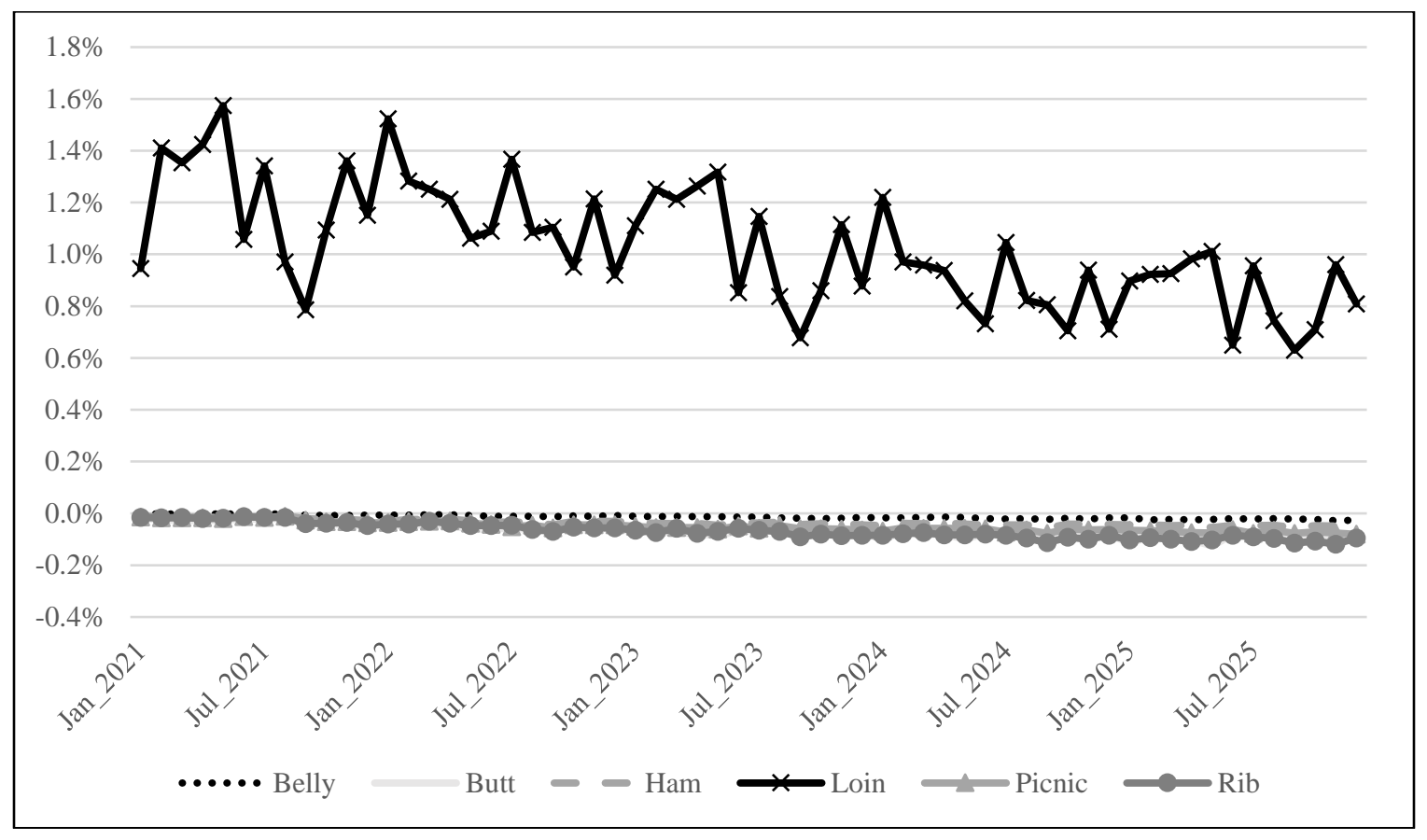




\section{Chapter 5.5 Decrease in Picnic Exports}

The impacts of a 10 percent decrease in picnic exports from the baseline values for each

month from January 2021 through December 2025 are summarized in Table 10.

Table 10. Impacts of Monthly 10 Percent Decrease in U.S. Picnic Exports from Baseline Values, January 2021 - December 2025

\begin{tabular}{|c|c|c|c|}
\hline Belly & $\begin{array}{c}\text { Short Run } \\
\text { Year } 1\end{array}$ & $\begin{array}{l}\text { Medium Run } \\
\text { Years 2-4 }\end{array}$ & $\begin{array}{c}\text { Longer Run } \\
\text { Year } 5\end{array}$ \\
\hline Average $\%$ change in cutout value & 0.16 & 0.43 & 0.64 \\
\hline Average $\%$ change in exports & -0.36 & -1.01 & -1.39 \\
\hline \multicolumn{4}{|l|}{ Butt } \\
\hline Average $\%$ change in cutout value & -0.14 & -0.03 & 0.10 \\
\hline Average $\%$ change in exports & -0.26 & -0.53 & -0.71 \\
\hline \multicolumn{4}{|l|}{ Ham } \\
\hline Average $\%$ change in cutout value & -0.47 & -0.38 & -0.23 \\
\hline Average $\%$ change in exports & -0.31 & -0.67 & -0.97 \\
\hline \multicolumn{4}{|l|}{ Loin } \\
\hline Average $\%$ change in cutout value & -0.13 & 0.10 & 0.24 \\
\hline Average $\%$ change in exports & -0.51 & -0.74 & -0.97 \\
\hline \multicolumn{4}{|l|}{ Picnic } \\
\hline Average $\%$ change in cutout value & -9.69 & -8.23 & -6.89 \\
\hline Average $\%$ change in exports & -4.45 & -4.72 & -4.85 \\
\hline \multicolumn{4}{|l|}{ Rib } \\
\hline Average $\%$ change in cutout value & -0.05 & 0.14 & 0.29 \\
\hline Average $\%$ change in exports & -0.38 & -0.75 & -1.00 \\
\hline \multicolumn{4}{|l|}{ Total } \\
\hline Average $\%$ change in cutout value & -0.76 & -0.53 & -0.33 \\
\hline Average $\%$ change in exports & -1.01 & -1.33 & -1.56 \\
\hline Average $\%$ change in production & -0.04 & -0.12 & -0.17 \\
\hline
\end{tabular}


Figure 21 shows the initial decrease in cutout value due to the loss in export demand for picnics and the response by producers to scale back pork production as prices decrease.

Figure 21. Percentage Change in Pork Cutout Value and Production as Result of Monthly 10 Percent Decrease in U.S. Picnic Exports from Baseline Values, Jan 2021 Dec 2025

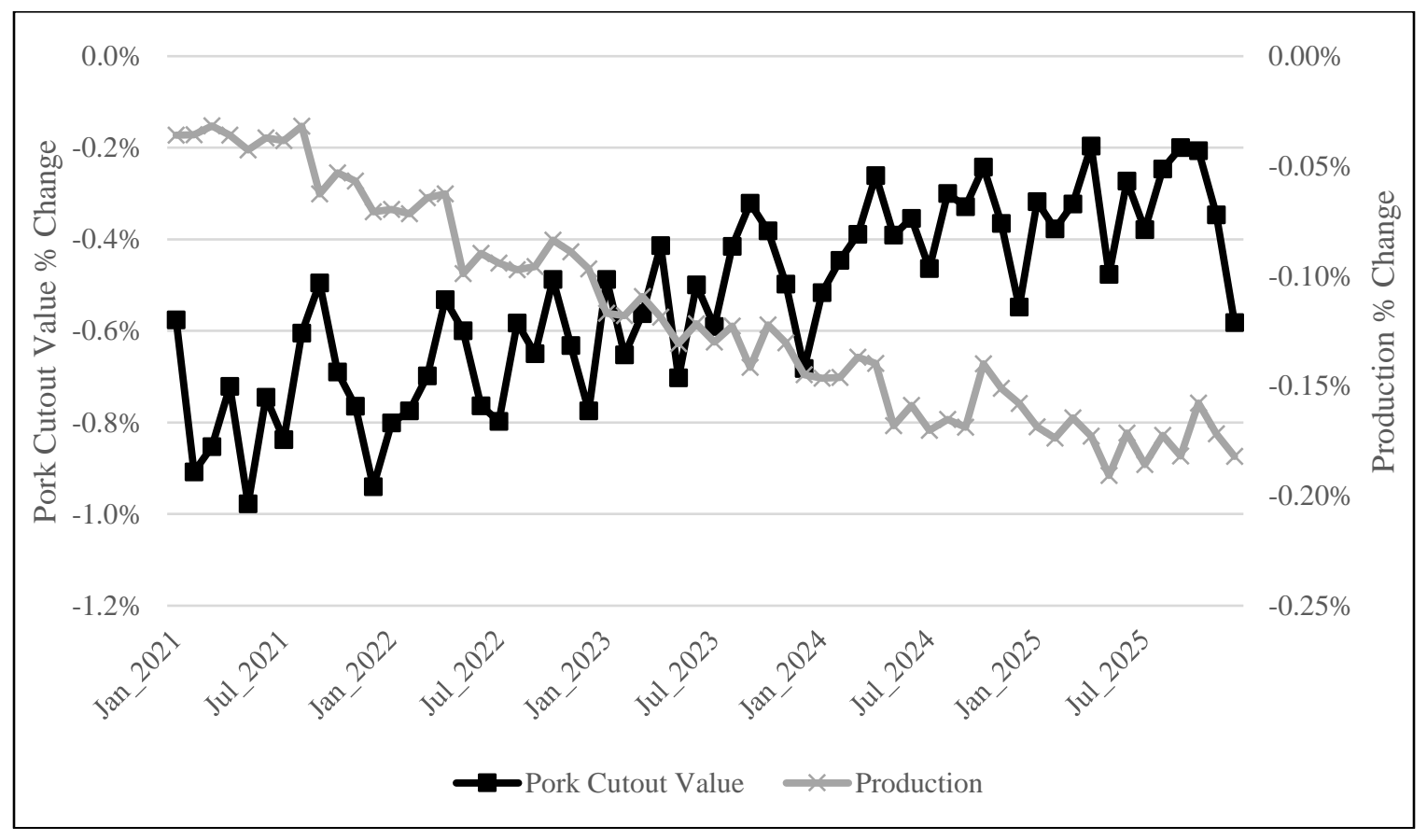


Decreasing picnic exports decreases exports of the other primal cuts as shown in Figure

22.

Figure 22. Percentage Change in Exports as Result of Monthly 10 Percent Decrease in U.S. Picnic Exports from Baseline Values, Jan 2021 - Dec 2025

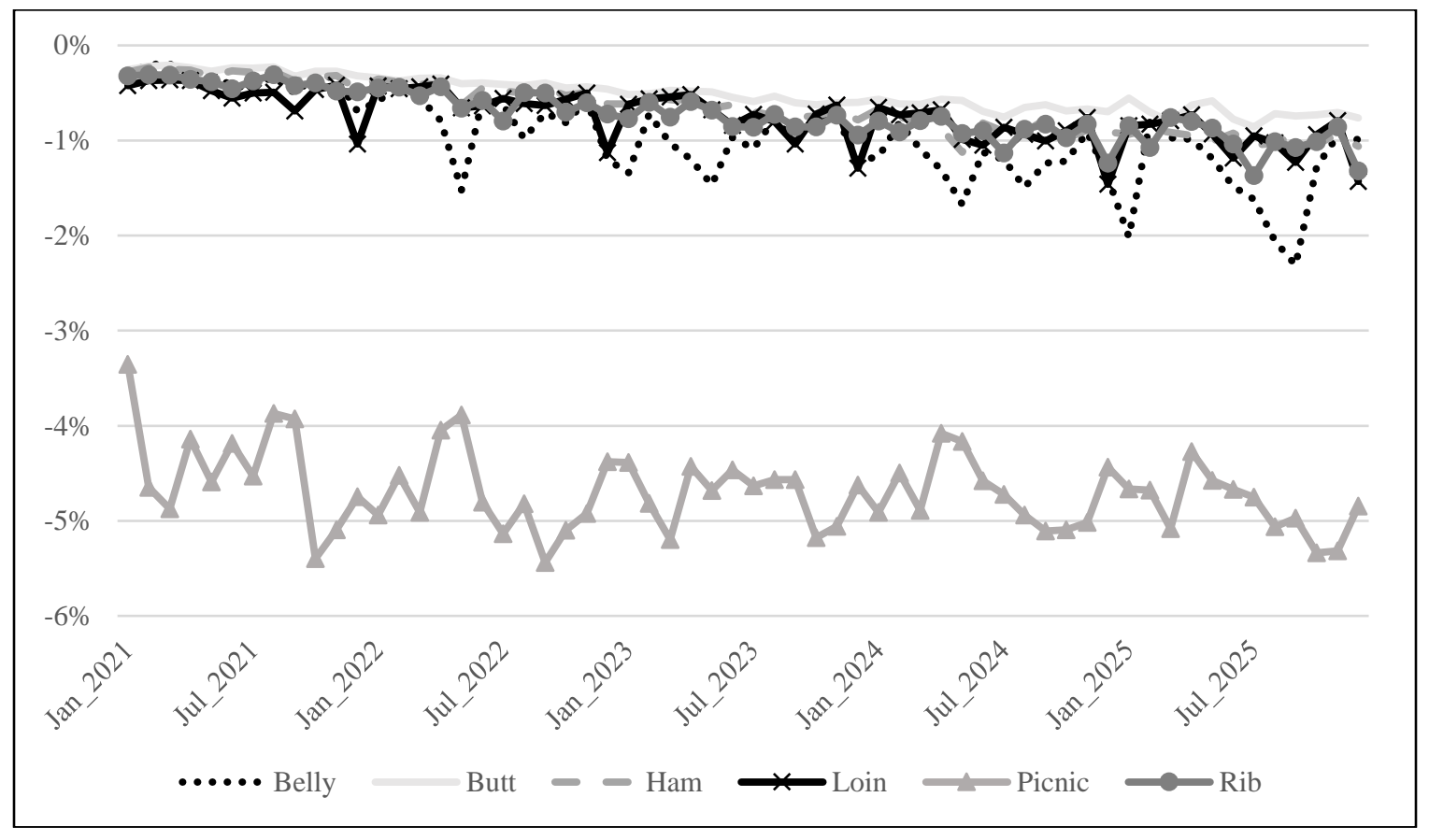


Decreasing picnic exports causes domestic disappearance of picnics to increase;

disappearance of the other cuts is nearly unchanged as shown in Figure 23.

Figure 23. Percentage Change in Domestic Disappearance as Result of Monthly 10

Percent Decrease in U.S. Picnic Exports from Baseline Values, Jan 2021 - Dec 2025

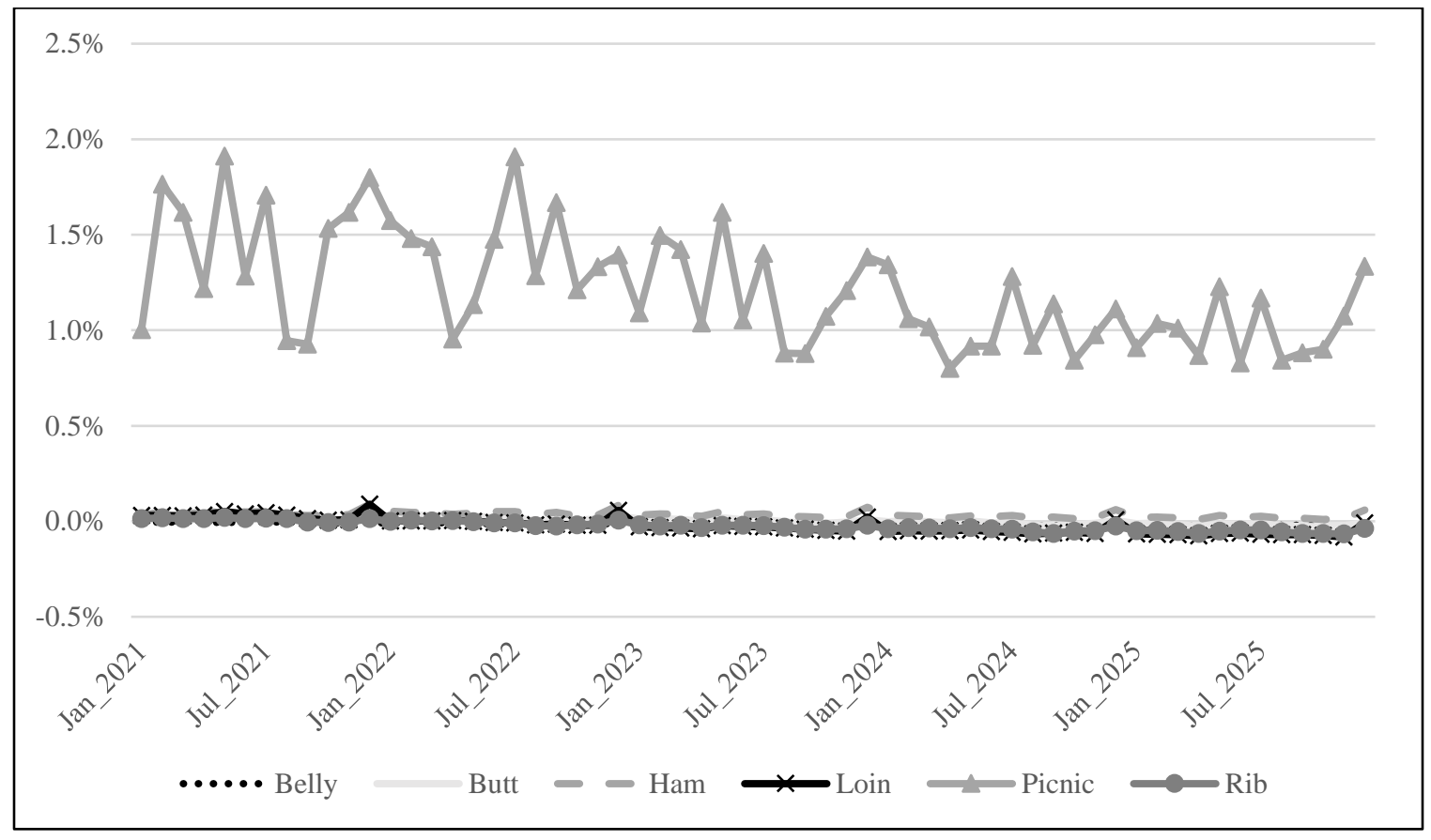




\section{Chapter 5.6 Decrease in Rib Exports}

Table 11 summarizes the effects of a 10 percent decrease in rib exports from the baseline values for each month from January 2021 through December 2025.

Table 11. Impacts of Monthly 10 Percent Decrease in U.S. Rib Exports from Baseline Values, January 2021 - December 2025

\begin{tabular}{|c|c|c|c|}
\hline & Short Run & Medium Run & Longer Run \\
\hline Belly & & & \\
\hline Average $\%$ change in cutout value & 0.08 & 0.19 & 0.30 \\
\hline Average $\%$ change in exports & -0.15 & -0.45 & -0.64 \\
\hline \multicolumn{4}{|l|}{ Butt } \\
\hline Average $\%$ change in cutout value & 0.04 & 0.10 & 0.16 \\
\hline Average $\%$ change in exports & -0.06 & -0.17 & -0.26 \\
\hline \multicolumn{4}{|l|}{ Ham } \\
\hline Average $\%$ change in cutout value & 0.06 & 0.15 & 0.20 \\
\hline Average $\%$ change in exports & -0.06 & -0.19 & -0.32 \\
\hline \multicolumn{4}{|l|}{ Loin } \\
\hline Average $\%$ change in cutout value & -0.01 & 0.04 & 0.09 \\
\hline Average $\%$ change in exports & -0.16 & -0.34 & -0.48 \\
\hline \multicolumn{4}{|l|}{ Picnic } \\
\hline Average $\%$ change in cutout value & 0.07 & 0.16 & 0.22 \\
\hline Average $\%$ change in exports & -0.05 & -0.16 & -0.27 \\
\hline \multicolumn{4}{|l|}{ Rib } \\
\hline Average $\%$ change in cutout value & -4.65 & -4.78 & -4.50 \\
\hline Average $\%$ change in exports & -5.64 & -6.41 & -6.60 \\
\hline \multicolumn{4}{|l|}{ Total } \\
\hline Average $\%$ change in cutout value & -0.32 & -0.24 & -0.16 \\
\hline Average $\%$ change in exports & -0.29 & -0.47 & -0.62 \\
\hline Average $\%$ change in production & -0.02 & -0.05 & -0.08 \\
\hline
\end{tabular}


Figure 24 displays the percentage changes in cutout value and production caused by the decrease in rib exports.

Figure 24. Percentage Change in Pork Cutout Value and Production as Result of Monthly 10 Percent Decrease in U.S. Rib Exports from Baseline Values, Jan 2021 - Dec 2025

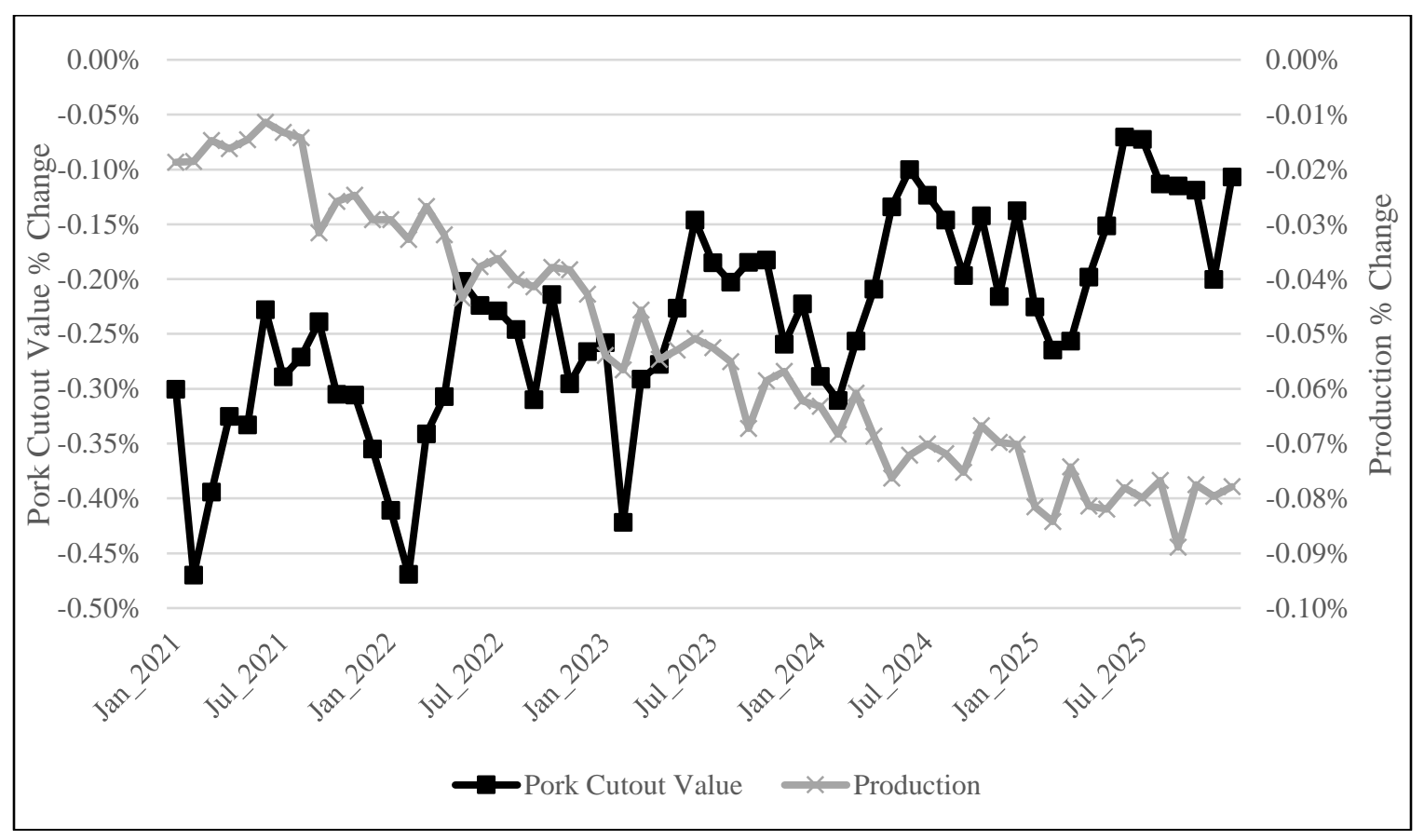


Figure 25 displays the decreases in exports of each of the cuts caused by decreasing the exports of ribs. While ribs see decreases in exports of up to 7 percent, the other cuts see little change in export amounts. Most likely, this is due to ribs comprising less than 5 percent of the pork carcass.

Figure 25. Percentage Change in Exports as Result of Monthly 10 Percent Decrease in U.S. Rib Exports from Baseline Values, Jan 2021 - Dec 2025

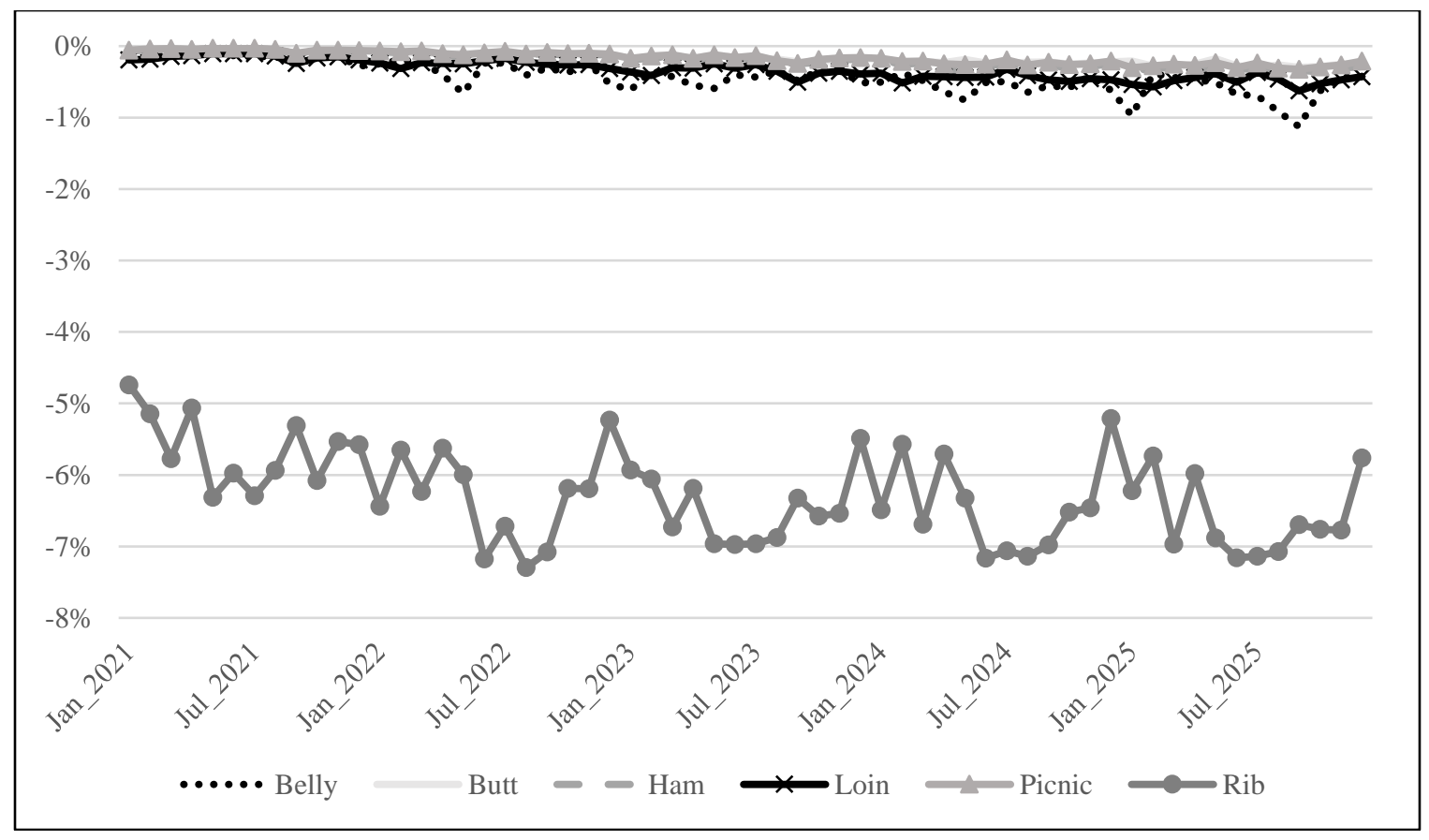


Finally, consider changes in domestic disappearance as shown in Figure 26. Ribs experience an increase in disappearance while the other cuts are left essentially unchanged.

Figure 26. Percentage Change in Domestic Disappearance as Result of Monthly 10 Percent Decrease in U.S. Rib Exports from Baseline Values, Jan 2021 - Dec 2025

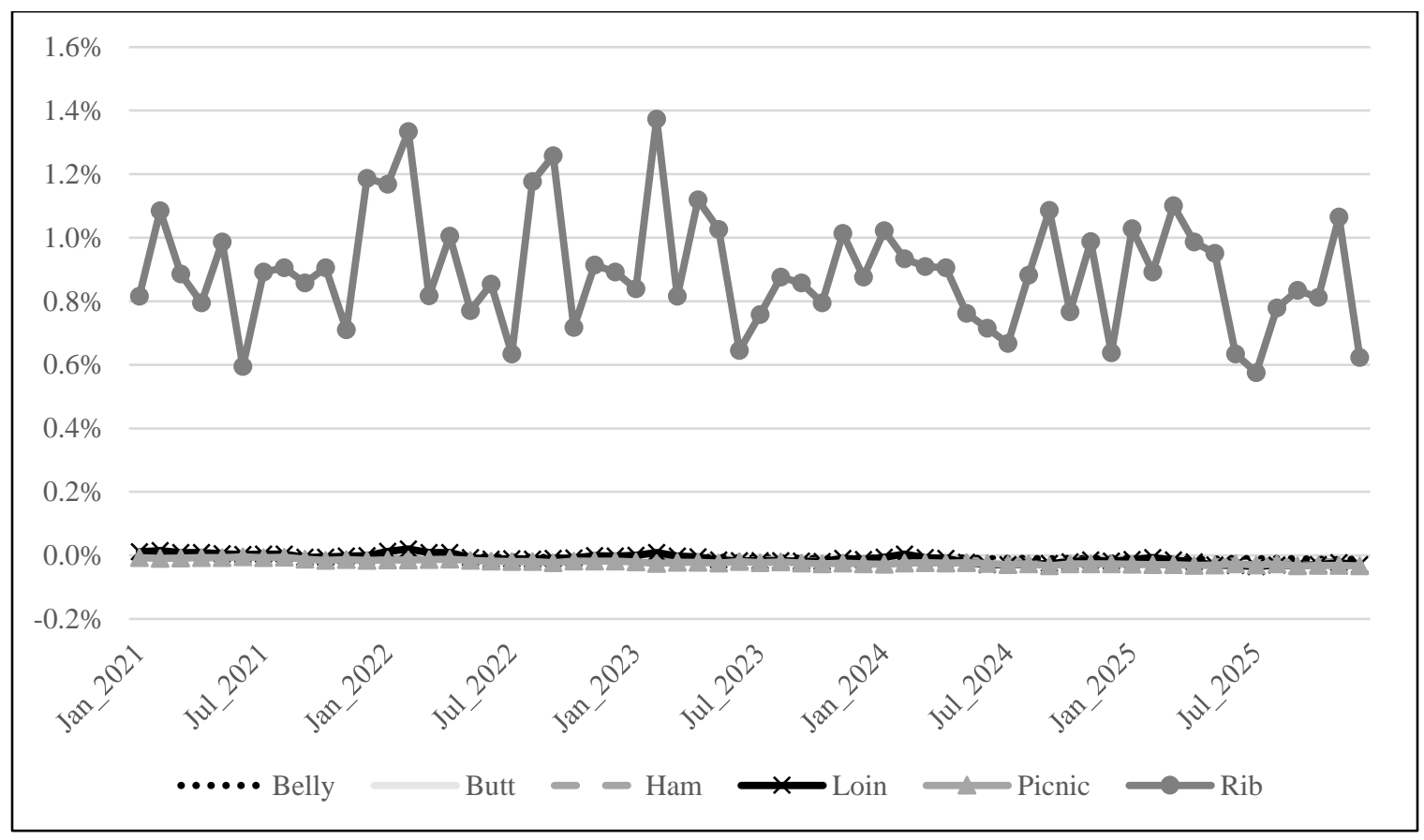

In summary, decreasing export demand for each of the cuts individually has disparate effects on domestic pork markets. Figure 27 displays the percentage change in production as a result of a 10 percent decrease in exports of each primal cut. Decreasing belly exports causes producers to decrease production the most because decreasing belly exports has the most detrimental impact on the pork cutout value as shown in Figure 28. Decreasing rib exports, on the other hand, has the least negative impact on production and the pork cutout value. Thus, export markets that have strong demands for belly cuts are the most vital to maintain in order to support the pork cutout value. 
Figure 27. Percentage Change in Production by Primal as Result of Monthly 10 Percent Decrease in U.S. Primal Exports from Baseline Values, Jan 2021 - Dec 2025

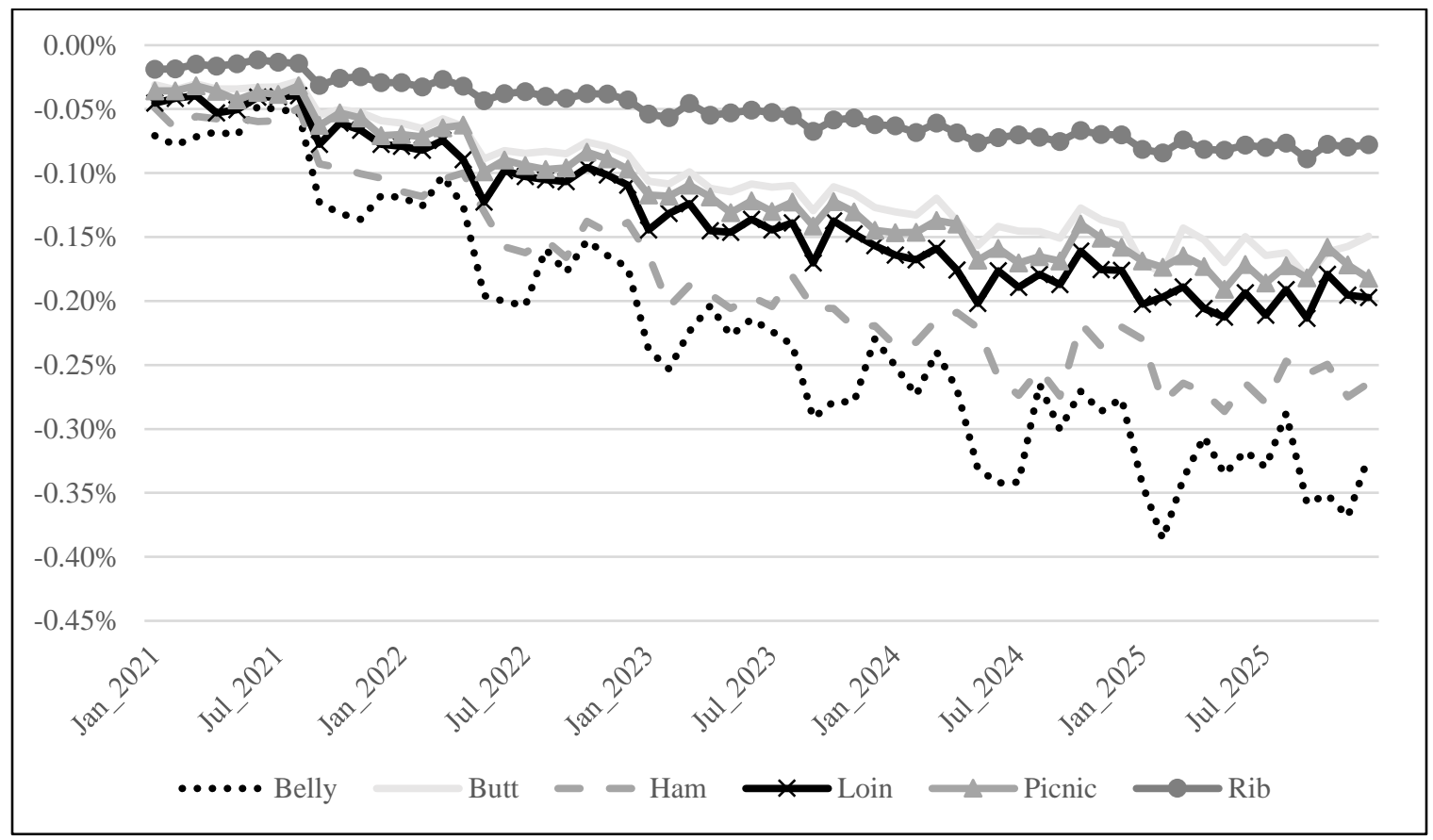

Figure 28. Percentage Change in Pork Cutout Value by Primal as Result of Monthly 10 Percent Decrease in U.S. Primal Exports from Baseline Values, Jan 2021 - Dec 2025

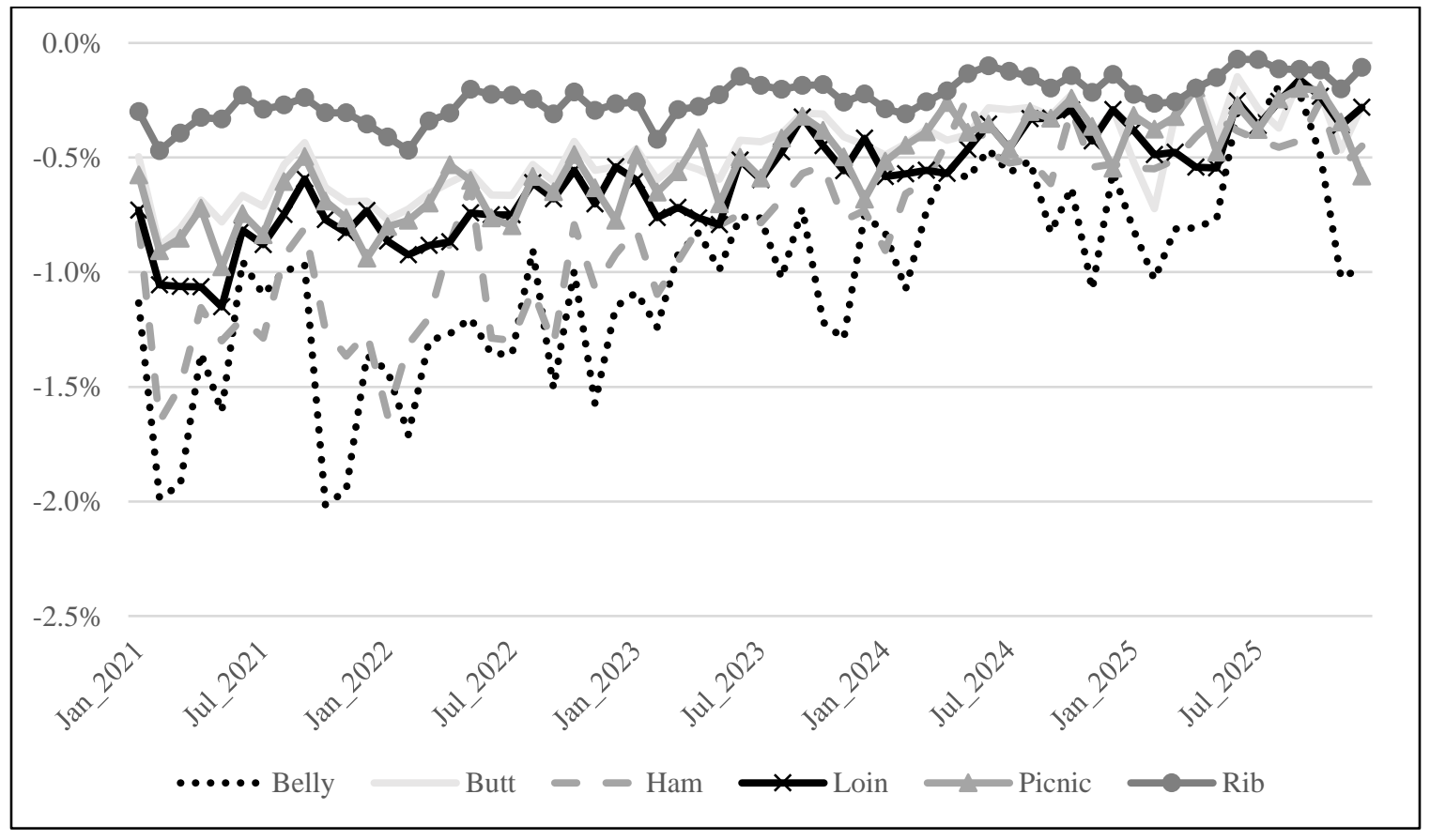




\section{Chapter 5.7 U.S. Pork Exports to China and Mexico}

The final two scenarios focus specifically on exports to China and Mexico. These two countries were chosen because of the increasingly vital role they play in U.S. pork exports as shown in Figure 29. In 2020, for example, nearly 57 percent of U.S. pork exports went to these two countries. ${ }^{32}$ To put that into perspective, 13 percent of the pork produced in the United States in 2020 was exported to either China or Mexico. ${ }^{33}$

Figure 29. U.S. Pork Exports to China, Mexico, and Rest of World (ROW)

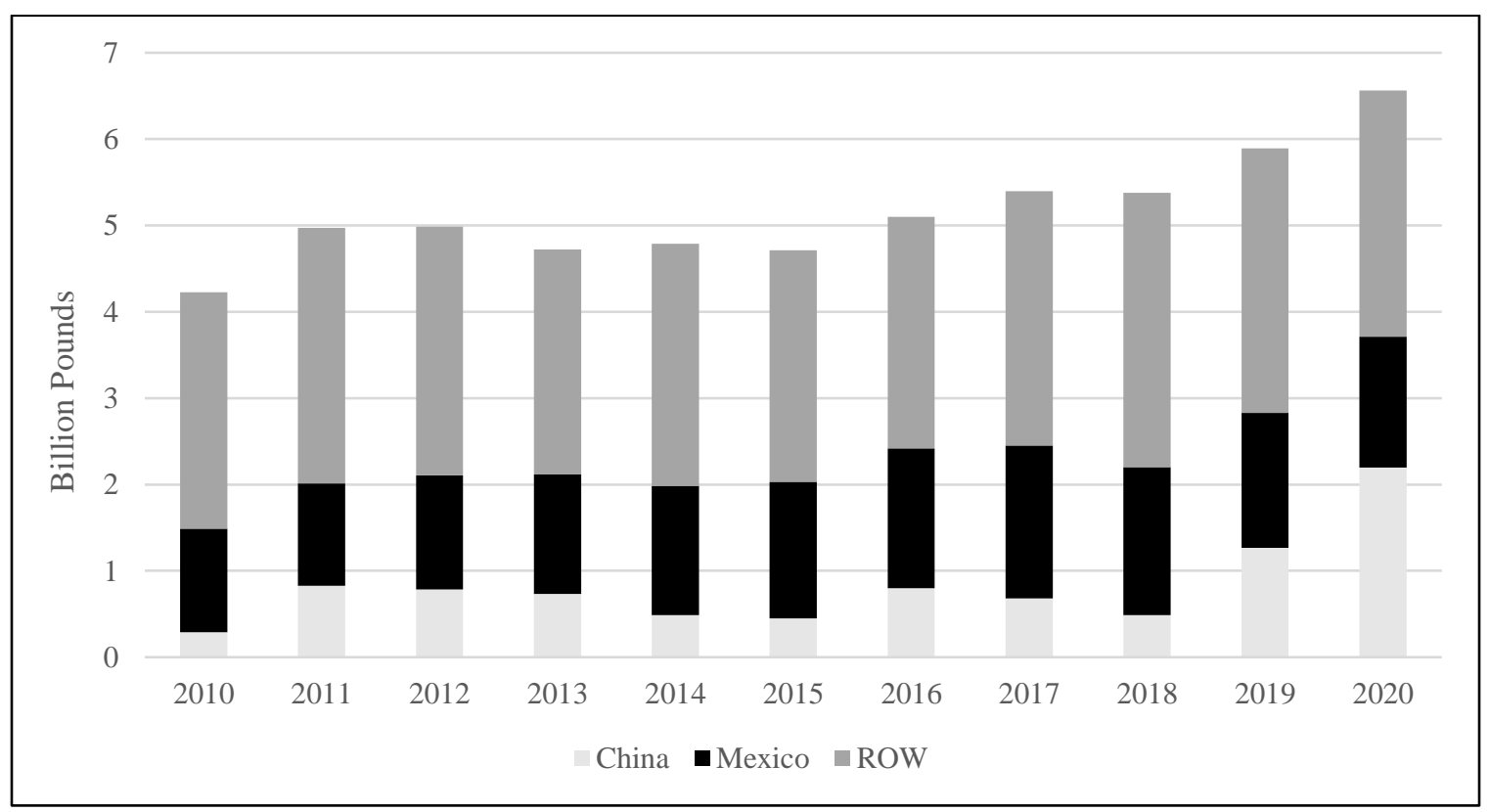

Sources: USDA Foreign Agricultural Service Global Agricultural Trade System \& USDA National Agricultural Statistics Service

The two markets vary greatly in the pork primal cuts they import from the United States, however. The majority of exports to Mexico are hams, whereas China has a more balanced mix. The U.S. Meat Export Federation (USMEF) estimated the breakdown of pork primal export shares to China and Mexico in $2020 .{ }^{34}$ They are summarized in Table

\footnotetext{
${ }^{32}$ USDA Foreign Agricultural Service Global Agricultural Trade System. (2021). Available at https://apps.fas.usda.gov/gats/default.aspx. [Accessed March 2021].

${ }^{33}$ USDA National Agricultural Statistics Service. (2021). "Pork, slaughter, commercial - production, measured in lb." Available at https://quickstats.nass.usda.gov/. [Accessed March 2021].

${ }^{34}$ U.S. Meat Export Federation. (2020). "U.S. pork export primal share estimates." [Excel spreadsheet].
} 
12. China is currently demanding a great deal of carcasses, most likely in an effort to efficiently fulfill the increase in demand caused by African swine fever (ASF) ravaging their domestic hog herd.

Table 12. USMEF Estimated U.S. Pork Primal Export Shares to China and Mexico in 2020

\begin{tabular}{|c|c|c|c|c|c|c|c|}
\hline Country & Belly & Butt & Ham & Loin & Picnic & Rib & Carcasses \\
\hline China & $0 \%$ & $15 \%$ & $20 \%$ & $0 \%$ & $15 \%$ & $5 \%$ & $45 \%$ \\
\hline Mexico & $2 \%$ & $4 \%$ & $70 \%$ & $5 \%$ & $17 \%$ & $1 \%$ & $1 \%$ \\
\hline
\end{tabular}

Both markets are clearly important to the U.S. pork cutout value. The following two scenarios explain the implications of decreasing exports to each market. 


\section{Chapter 5.8 Decrease in China Exports}

Table 13 summarizes the impacts of decreasing the baseline values of exports to China by

10 percent for each month spanning from January 2021 through December 2025.

Table 13. Impacts of Monthly 10 Percent Decrease in U.S. Exports to China from Baseline Values, January 2021 - December 2025

\begin{tabular}{|c|c|c|c|}
\hline & $\begin{array}{l}\text { Short Run } \\
\text { Year } 1\end{array}$ & $\begin{array}{l}\text { Medium Run } \\
\text { Years 2-4 }\end{array}$ & $\begin{array}{l}\text { Longer Run } \\
\text { Year } 5\end{array}$ \\
\hline Belly & & & \\
\hline Average $\%$ change in cutout value & -1.43 & -0.79 & -0.51 \\
\hline Average $\%$ change in exports & -1.39 & -2.77 & -3.53 \\
\hline \multicolumn{4}{|l|}{ Butt } \\
\hline Average $\%$ change in cutout value & -1.94 & -1.43 & -1.05 \\
\hline Average $\%$ change in exports & -1.49 & -1.90 & -2.27 \\
\hline \multicolumn{4}{|l|}{ Ham } \\
\hline Average $\%$ change in cutout value & -2.08 & -1.63 & -1.13 \\
\hline Average $\%$ change in exports & -0.99 & -1.70 & -2.33 \\
\hline \multicolumn{4}{|l|}{ Loin } \\
\hline Average $\%$ change in cutout value & -1.22 & -0.61 & -0.28 \\
\hline Average $\%$ change in exports & -2.61 & -3.00 & -3.58 \\
\hline \multicolumn{4}{|l|}{ Picnic } \\
\hline Average $\%$ change in cutout value & -2.71 & -1.90 & -1.43 \\
\hline Average $\%$ change in exports & -1.52 & -2.07 & -2.59 \\
\hline \multicolumn{4}{|l|}{ Rib } \\
\hline Average $\%$ change in cutout value & -1.43 & -0.75 & -0.38 \\
\hline Average $\%$ change in exports & -2.37 & -2.86 & -3.39 \\
\hline \multicolumn{4}{|l|}{ Total } \\
\hline Average $\%$ change in cutout value & -1.64 & -1.06 & -0.70 \\
\hline Average $\%$ change in exports & -1.57 & -2.20 & -2.77 \\
\hline Average $\%$ change in production & -0.10 & -0.26 & -0.37 \\
\hline
\end{tabular}


Figure 30 shows the percentage changes in cutout value and production caused by the decrease in exports to China.

Figure 30. Percentage Change in Pork Cutout Value and Production as Result of Monthly 10 Percent Decrease in U.S. Exports to China from Baseline Values, Jan 2021 Dec 2025

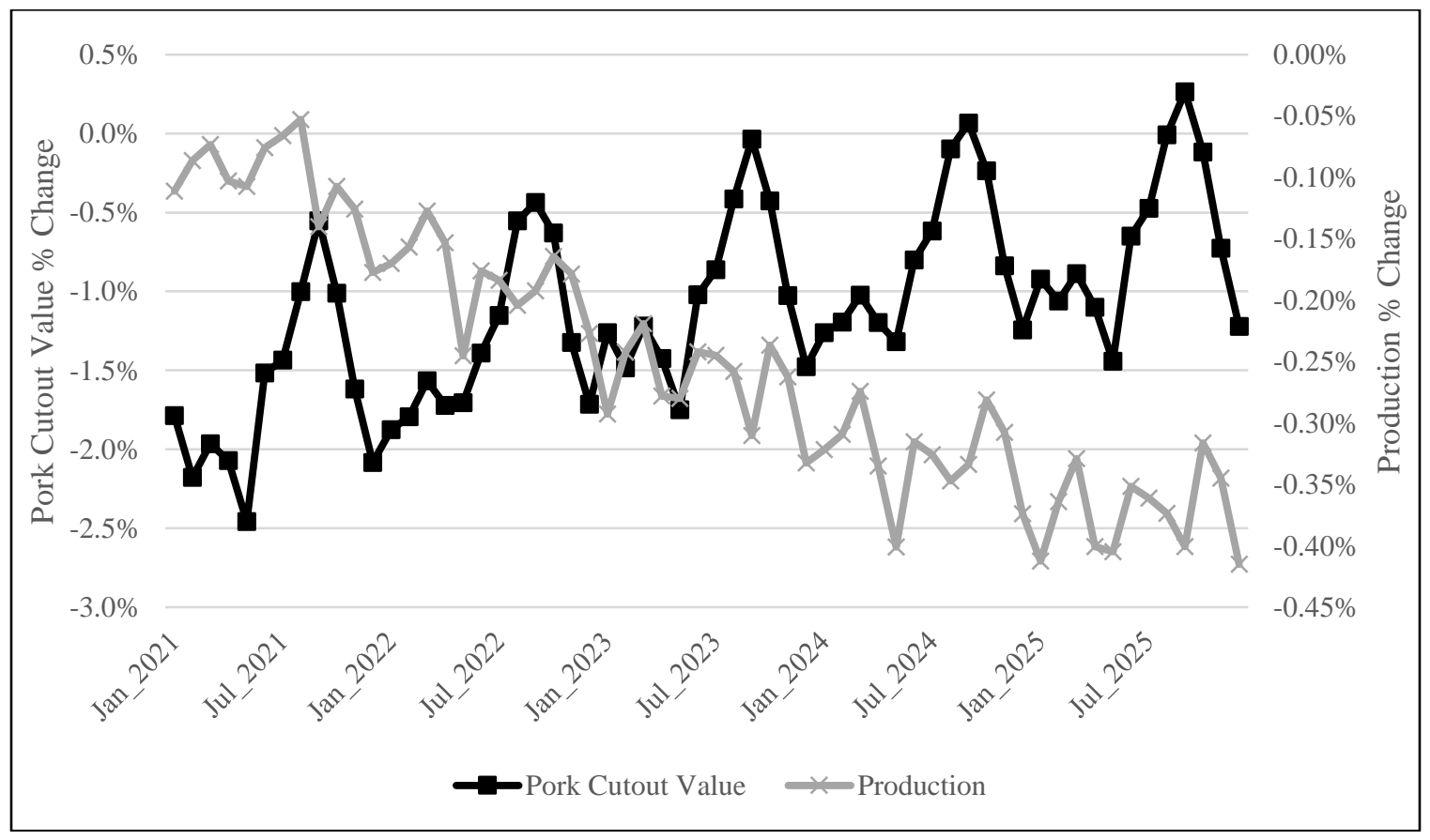


Changes in cutout values for the primal cuts are shown in Figure 31. Note that all cuts see decreases in cutout value, but picnics, hams, and butts sustain the greatest decreases.

Figure 31. Percentage Change in Pork Primal Cutout Values as Result of Monthly 10 Percent Decrease in U.S. Exports to China from Baseline Values, Jan 2021 - Dec 2025

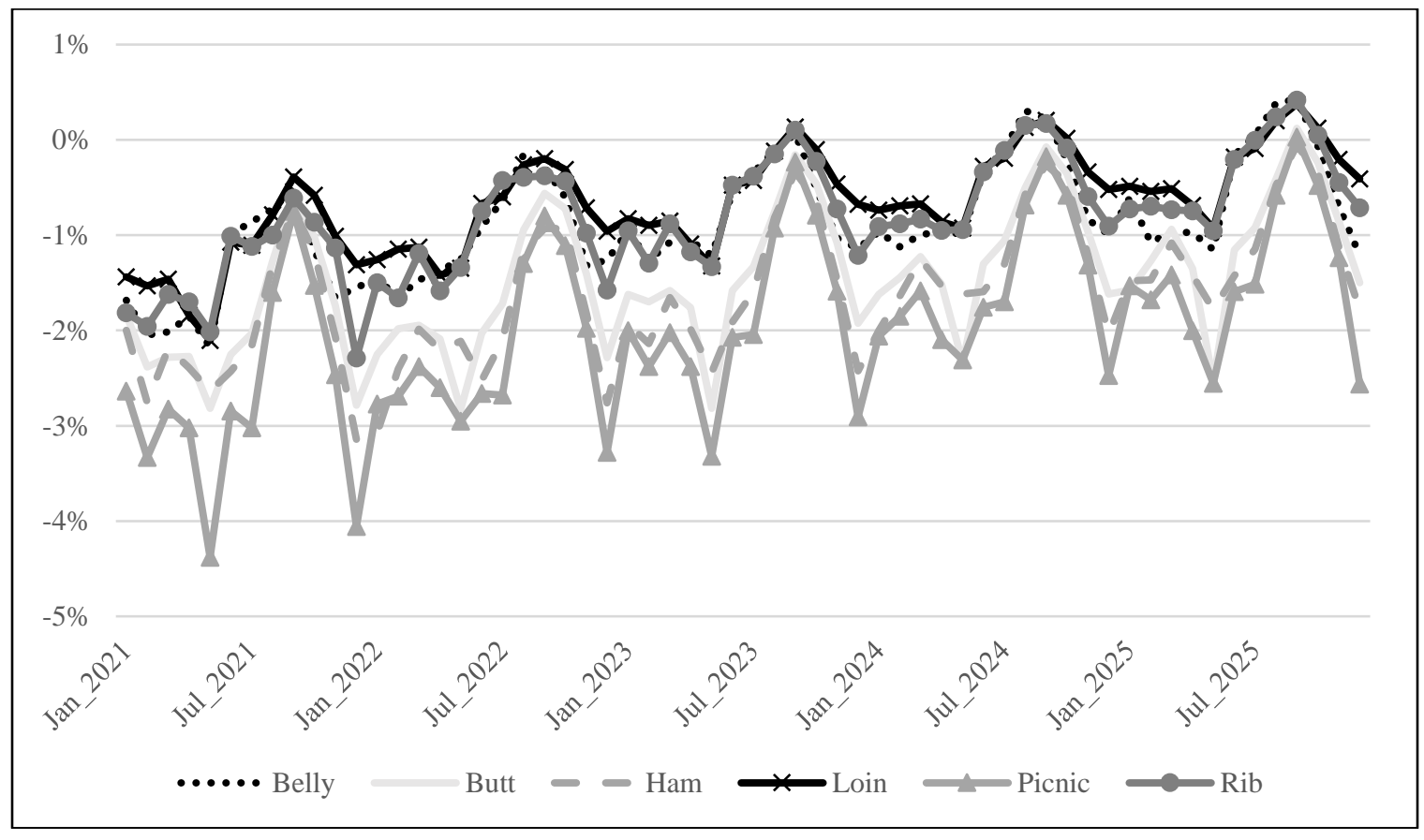


Figure 32 displays the decreases in exports of each of the cuts caused by decreasing the exports to China. Each of the cuts experiences decreases in exports, with bellies, loins, and ribs experiencing the greatest decreases.

Figure 32. Percentage Change in Exports as Result of Monthly 10 Percent Decrease in U.S. Exports to China from Baseline Values, Jan 2021 - Dec 2025

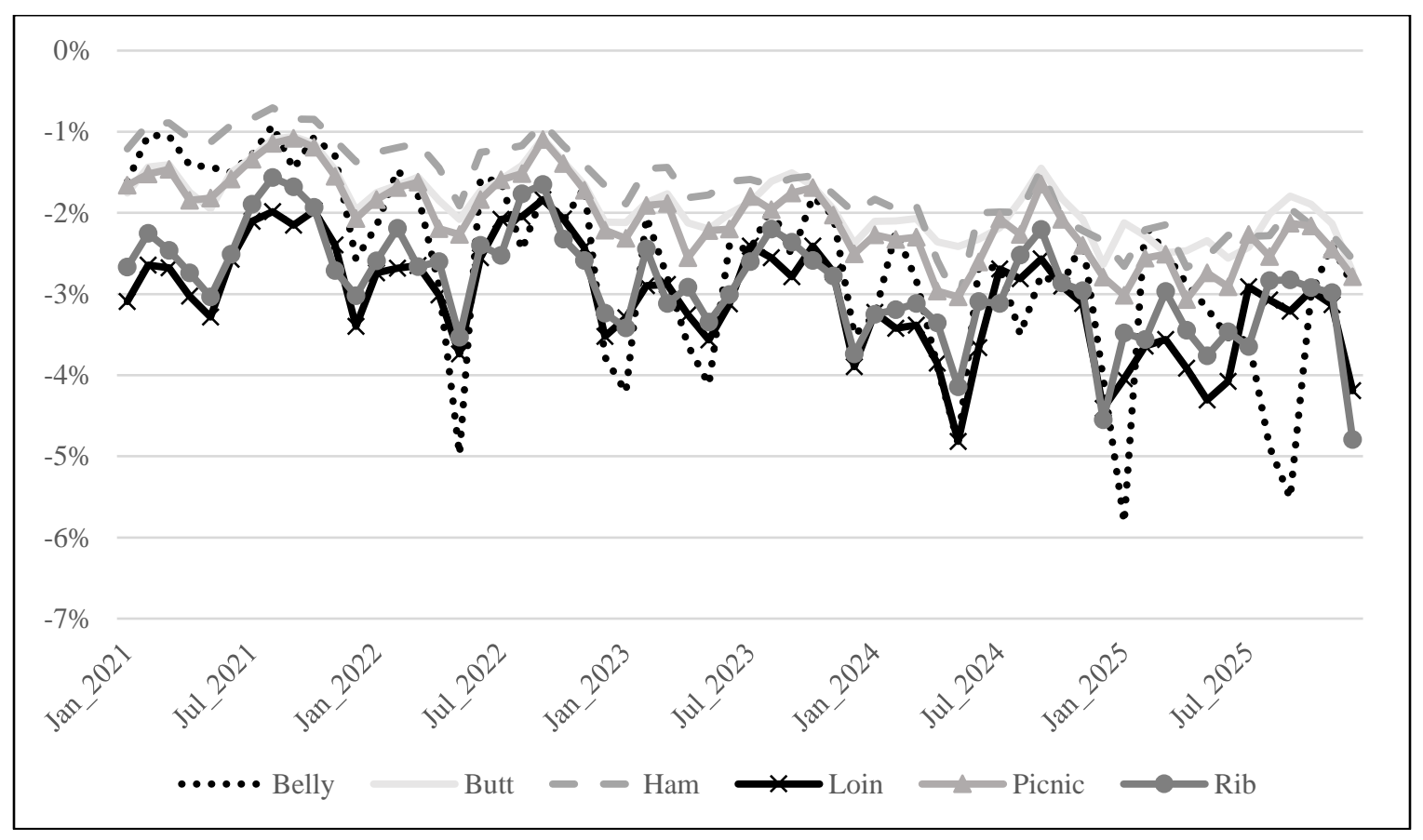


Finally, consider changes in domestic disappearance as a result of decreasing exports to China. Figure 33 shows that disappearance increases for of each of the cuts.

Figure 33. Percentage Change in Domestic Disappearance as Result of Monthly 10 Percent Decrease in U.S. Exports to China from Baseline Values, Jan 2021 - Dec 2025

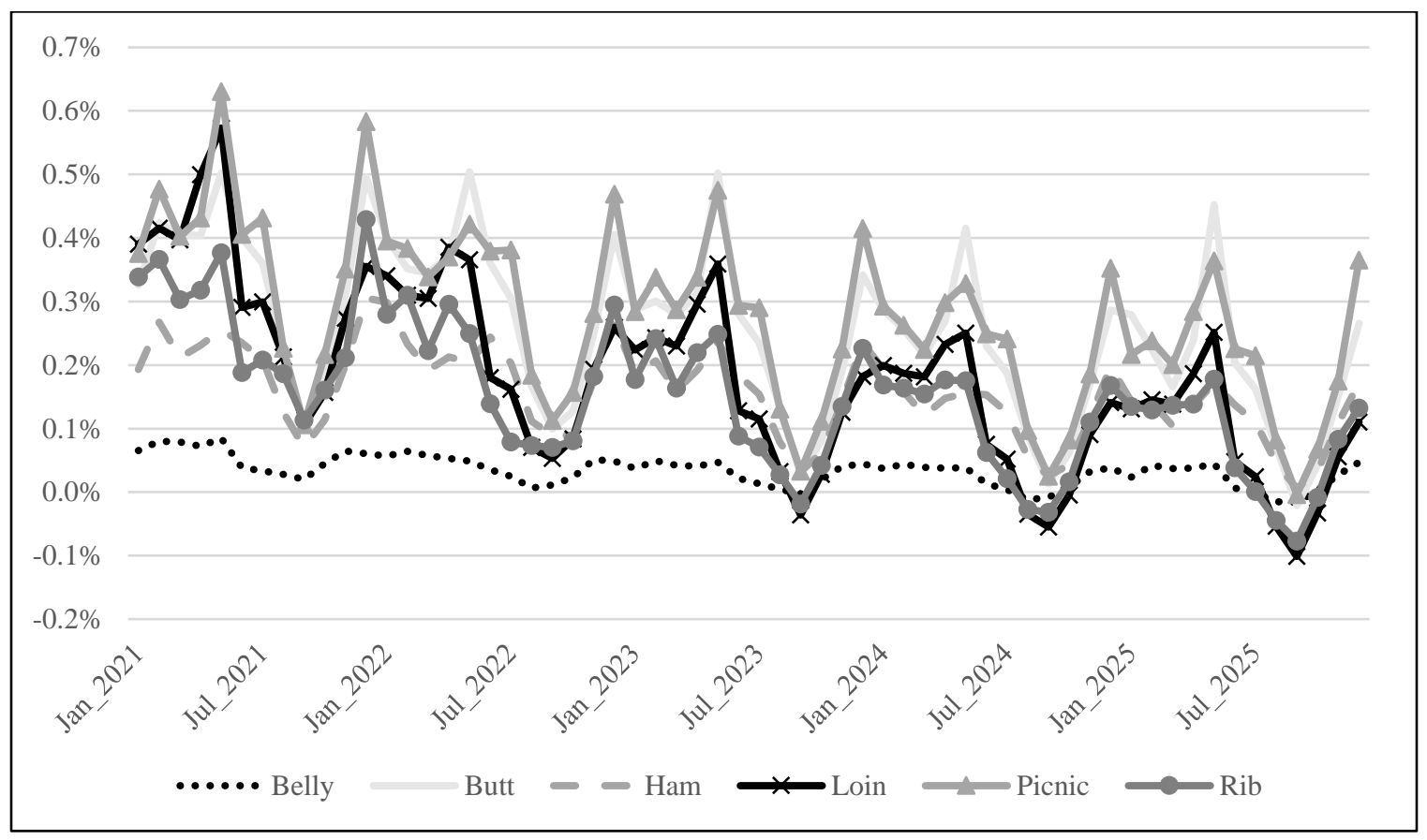

It is safe to say that losing even 10 percent of exports to China would be detrimental to the U.S. pork industry as evidenced by this scenario. Exports of bellies, loins, and ribs would be the most negatively impacted if China scales back their purchases. The cutout values for butts, hams, and picnics would see the greatest percentage decreases of the cuts. Overall, China is a key player in U.S. pork markets, and the shares of pork primal cuts they demand play a role in determining the U.S. pork cutout value.

\section{Chapter 5.9 Decrease in Mexico Exports}

Export equations for Mexico were not estimated. Therefore, to run a 10 percent decrease in exports to Mexico, the ROW export equation was used. Using USMEF's export share and accompanying export volumes, the shares of ROW exports that went to Mexico of 
each of the primal cuts were calculated. These shares are summarized in Table 14. The 10 percent shock was imposed by decreasing each cut's ROW baseline export values by 10 percent of their respective total export share percentages outlined in Table 14.

Table 14. USMEF Estimated Mexico Shares of ROW Exports in 2020

\begin{tabular}{|c|c|c|c|c|c|}
\hline Belly & Butt & Ham & Loin & Picnic & Rib \\
\hline $65 \%$ & $36 \%$ & $73 \%$ & $47 \%$ & $34 \%$ & $21 \%$ \\
\hline
\end{tabular}

As shown in Table 15, decreasing exports to Mexico is the most detrimental to the ham cutout value. Losing 10 percent of the Mexican markets results in a nearly 3 percent decrease in ham cutout value in the first year.

Table 15. Impacts of Monthly 10 Percent Decrease in U.S. Exports to Mexico from Baseline Values, January 2021 - December 2025

\begin{tabular}{|c|c|c|c|}
\hline Belly & $\begin{array}{l}\text { Short Run } \\
\text { Year } 1\end{array}$ & $\begin{array}{l}\text { Medium Run } \\
\text { Years 2-4 }\end{array}$ & $\begin{array}{c}\text { Longer Run } \\
\text { Year } 5\end{array}$ \\
\hline Average $\%$ change in cutout value & -0.42 & -0.14 & -0.13 \\
\hline Average $\%$ change in exports & -0.62 & -1.34 & -1.55 \\
\hline \multicolumn{4}{|l|}{ Butt } \\
\hline Average $\%$ change in cutout value & -1.23 & -0.80 & -0.49 \\
\hline Average $\%$ change in exports & -0.91 & -1.04 & -1.06 \\
\hline \multicolumn{4}{|l|}{ Ham } \\
\hline Average $\%$ change in cutout value & -2.92 & -1.73 & -0.74 \\
\hline Average $\%$ change in exports & -1.06 & -1.17 & -1.19 \\
\hline \multicolumn{4}{|l|}{ Loin } \\
\hline Average $\%$ change in cutout value & -0.59 & -0.17 & 0.10 \\
\hline Average $\%$ change in exports & -1.34 & -1.34 & -1.26 \\
\hline \multicolumn{4}{|l|}{ Picnic } \\
\hline Average $\%$ change in cutout value & -1.36 & -0.68 & -0.28 \\
\hline Average $\%$ change in exports & -0.80 & -0.94 & -1.01 \\
\hline \multicolumn{4}{|l|}{ Rib } \\
\hline Average $\%$ change in cutout value & -0.16 & 0.15 & 0.32 \\
\hline Average $\%$ change in exports & -0.61 & -0.86 & -0.97 \\
\hline \multicolumn{4}{|l|}{ Total } \\
\hline Average $\%$ change in cutout value & -1.03 & -0.52 & -0.20 \\
\hline Average $\%$ change in exports & -0.99 & -1.15 & -1.19 \\
\hline Average $\%$ change in production & -0.06 & -0.14 & -0.18 \\
\hline
\end{tabular}


While the pork cutout value experiences sharp decreases in the first two years as shown in Figure 34, it does nearly recover by years four and five as producers back off production to account for the loss in exports to Mexico.

Figure 34. Percentage Change in Pork Cutout Value and Production as Result of Monthly 10 Percent Decrease in U.S. Exports to Mexico from Baseline Values, Jan 2021 - Dec 2025

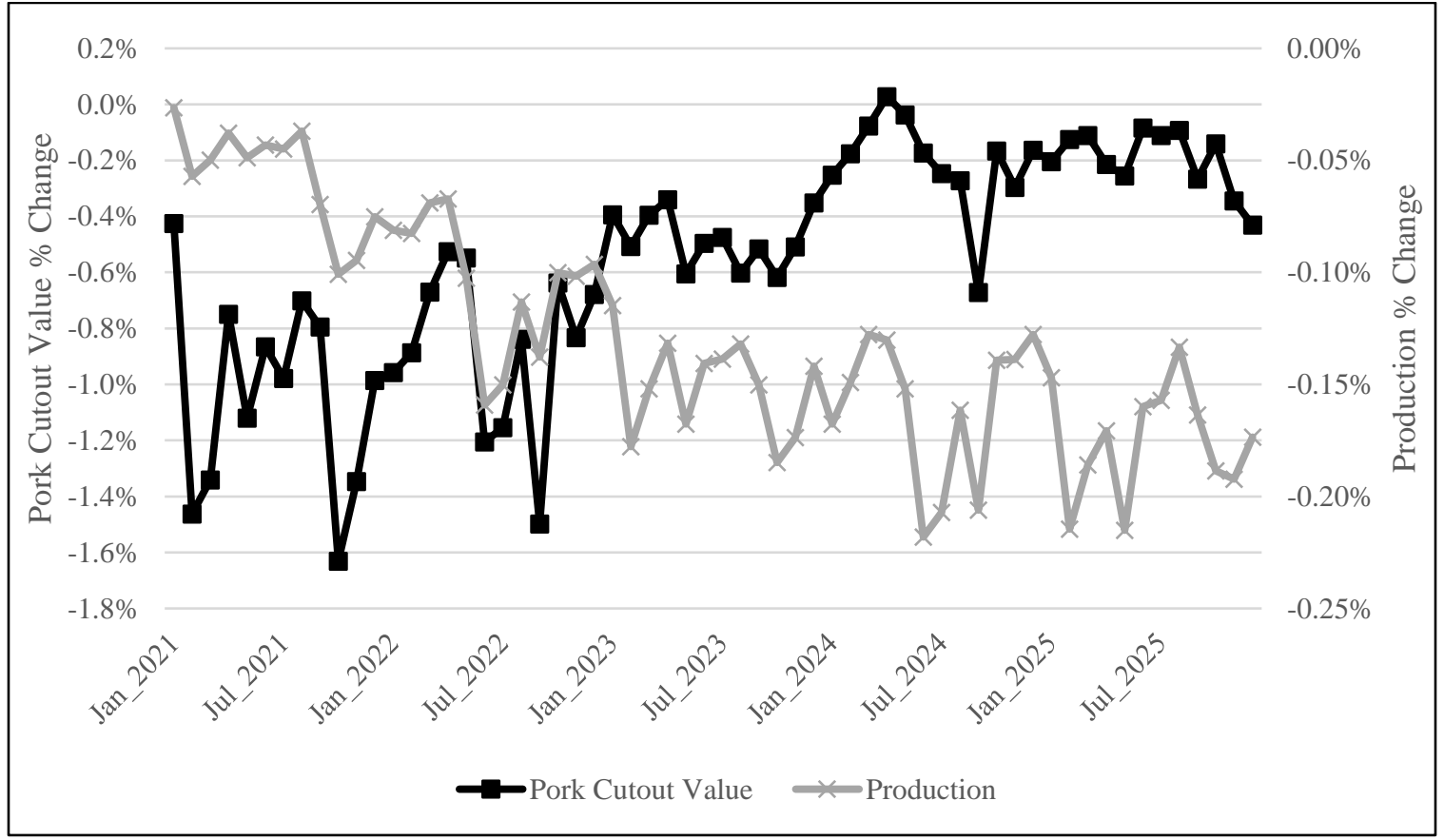


Changes in cutout values for the primal cuts are shown in Figure 35. Note that hams see the greatest decrease in cutout value followed by picnics. Interestingly, however, the belly, loin, and rib cuts see small increases in cutout values over time.

Figure 35. Percentage Change in Primal Cutout Values as Result of Monthly 10 Percent Decrease in U.S. Exports to Mexico from Baseline Values, Jan 2021 - Dec 2025

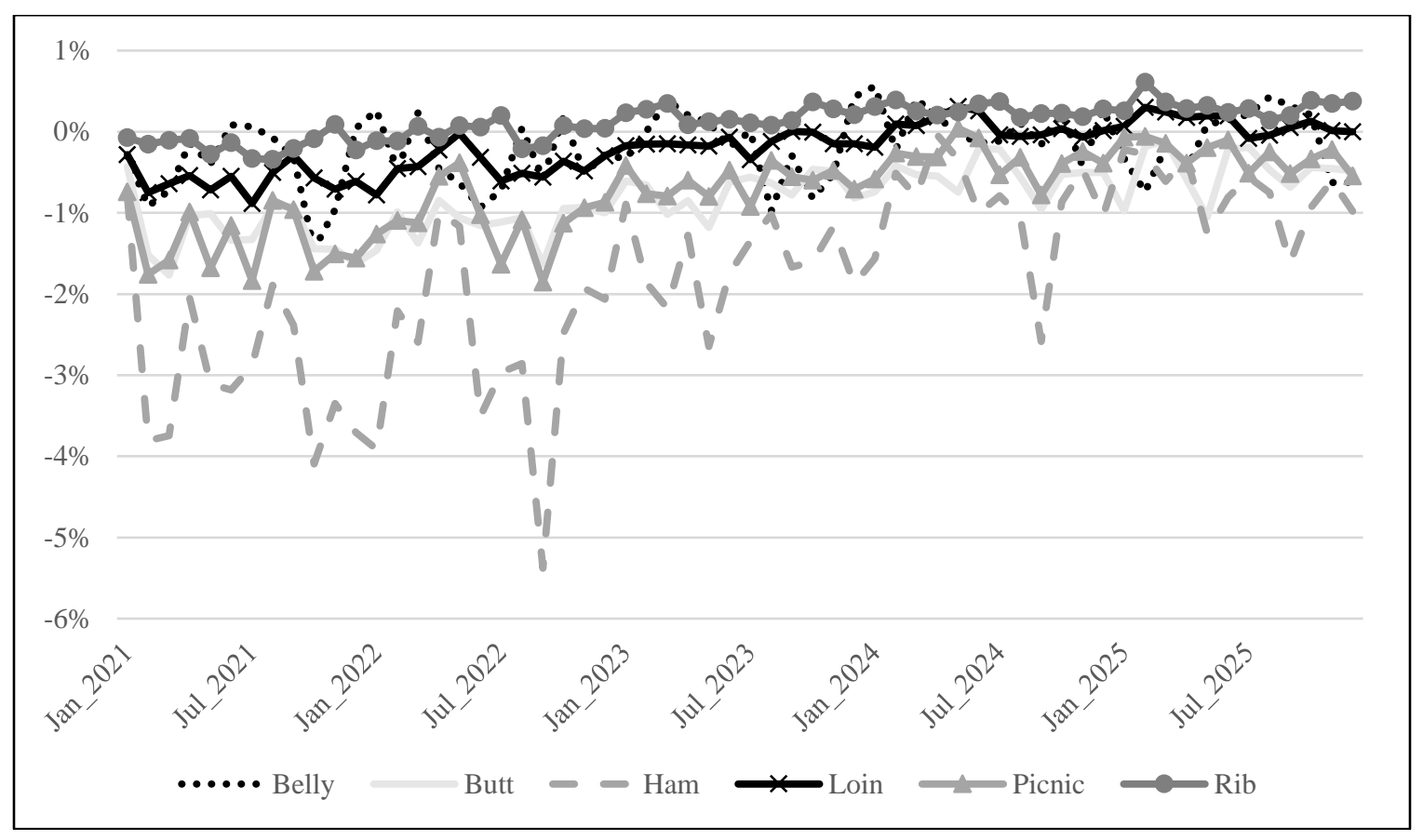


Figure 36 displays the detrimental impact that losing 10 percent of the Mexican market has on exports of the primal cuts. Belly, ham, and loin exports are the most negatively impacted.

Figure 36. Percentage Change in Exports as Result of Monthly 10 Percent Decrease in U.S. Exports to Mexico from Baseline Values, Jan 2021 - Dec 2025

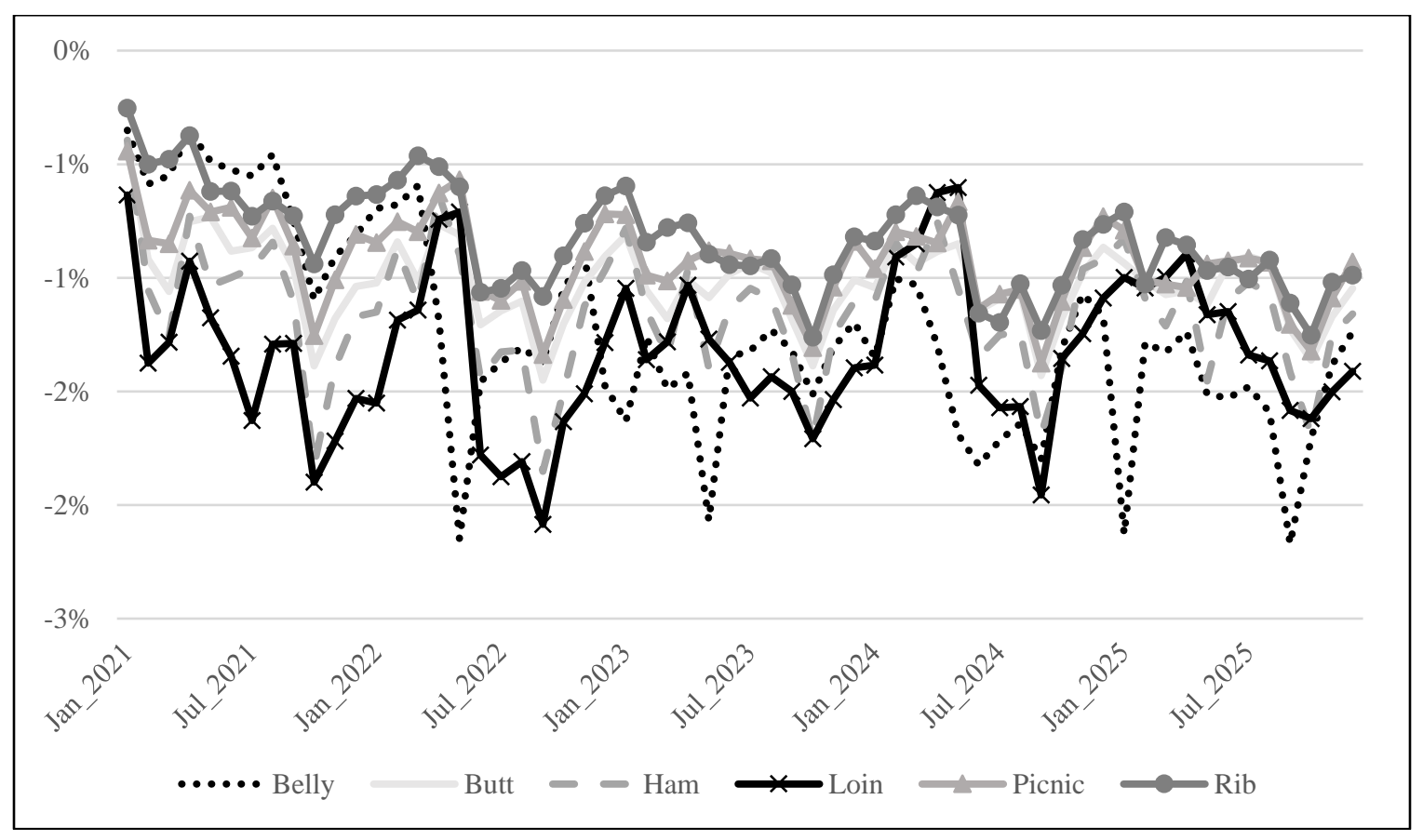


Domestic disappearance of butts, hams, and picnics increases the most as a result of decreasing exports to Mexico. The remaining cuts see slight decreases in domestic disappearance over time as shown in Figure 37.

Figure 37. Percentage Change in Domestic Disappearance as Result of Monthly 10 Percent Decrease in U.S. Exports to Mexico from Baseline Values, Jan 2021 - Dec 2025

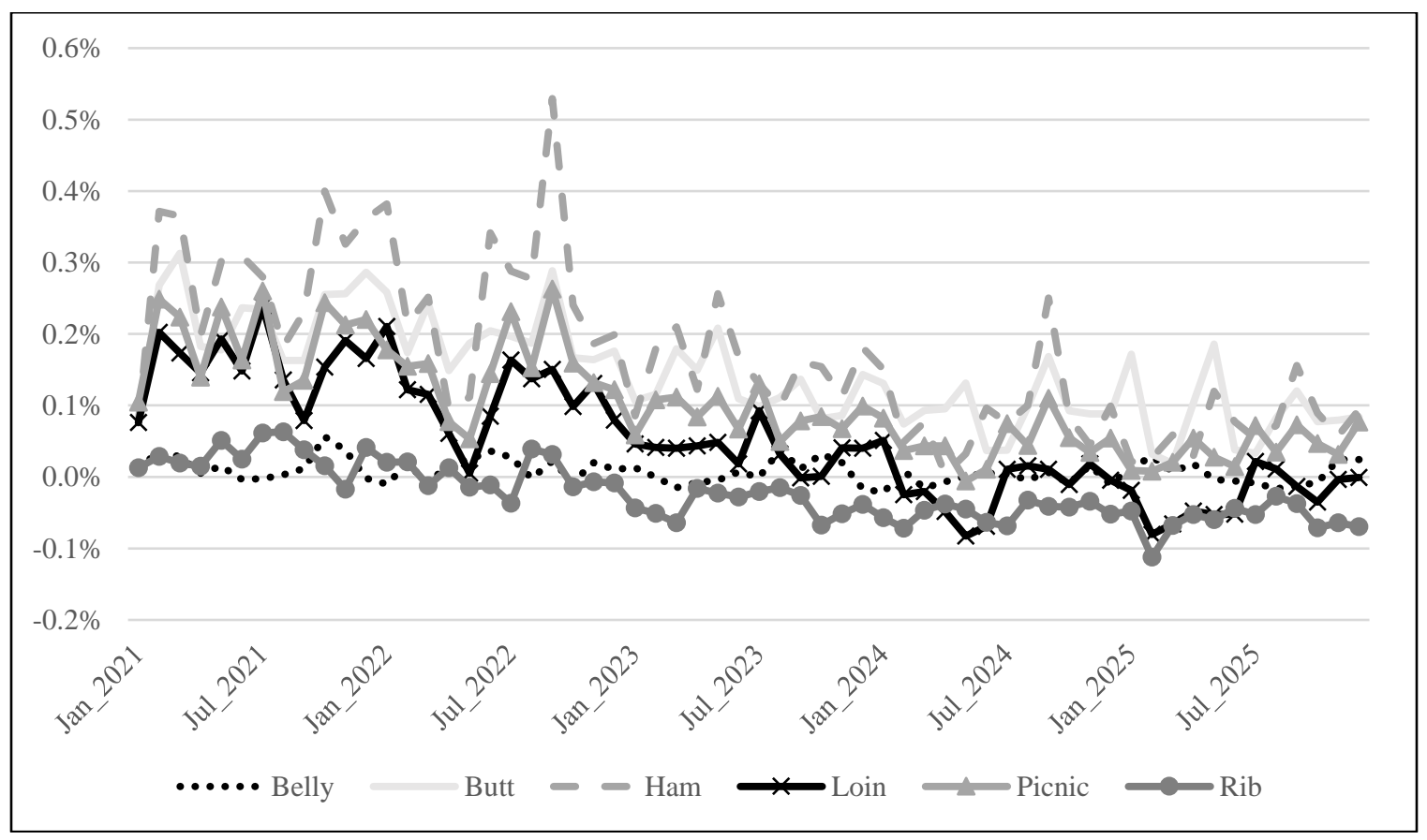

Overall, Mexico is obviously a key market for U.S. pork, and the share of primal cuts that they demand matters. A 10 percent decrease in pork exports to Mexico results in a major market loss for U.S. hams. As discussed above, this has repercussions on the ham cutout value as well as the pork cutout value as a whole. 


\section{Chapter 6 Conclusion}

Chapter 5 results encompass the purpose of identifying the nuances of pork by investigating further than just at the commodity level. This research found that there are indeed differences among demands for pork primal cuts and those differences can translate into disparate impacts on primal cutout values and the pork cutout value as a whole. Being able to demonstrate, for example, in Figure 35 that decreasing exports to Mexico actually increases the cutout value of belly, loin, and rib cuts over time is the crux of this study.

Oftentimes, producers, reporters, and even analysts can misstate the implications of increasing or decreasing exports to various countries because the demands for products, such as the various primal cuts of pork, are not fully understood. This study aimed to shed light on some of the information that can be gleaned if one makes the effort to dig deeper and better understand the situation at hand.

Of course, there were difficulties encountered along the way, such as the ambiguous trade data codes. It is impossible to capture all the industry specifics in an economic model, but this is the best effort to include more detail at the specific cut level to comprise an educated estimate that in turn enabled the desired research to be completed. Moving forward and in a perfect world, it would be fantastic if information could be more harmonized among U.S. departmental agencies and international entities. While this hindrance is detrimental to the accuracy and ease of work in this field, it does not stifle it completely. 
Hopefully, future research can be completed using the methods and knowledge garnered from this study to analyze other scenarios, such as effects of an ASF outbreak in the United States or decreasing domestic demand due to decreased incomes as a result of the pandemic. Ultimately, this economic model has potential to influence decision making from the farmer to the consumer and the numerous stakeholders in between, and my hope is that it will be used to do so. 


\section{$\underline{\text { References }}$}

Blythe, B. (2019, June 4). "Bacon Demand Is Higher Than Ever as Price Volatility Grows." CME Group. Available at https://seekingalpha.com/article/4268131bacon-demand-is-higher-ever-price-volatility-grows. [Accessed January 2021.]

Capps, O., Jr., D.E. Farris, P.J. Byrne, J.C. Namken, and C.D. Lambert. (1994). "Determinants of Wholesales Beef-Cut Prices." Journal of Agricultural and Applied Economics, 26(1), 183-199.

Chavas, J.P. (1982). "Structural Change in the Demand for Meat." American Journal of Agricultural Economics, 65(1), 148-153.

Eales, J.S., and L.J. Unnevehr. (1988). "Demand for Beef and Chicken Products: Separability and Structural Change." American Journal of Agricultural Economics, 70(3), 521-532.

Federal Reserve Bank of St. Louis. (2020). "Consumer Price Index for All Urban Consumers: All Items in U.S. City Average, Index 1982-1984=100, Monthly, Seasonally Adjusted.” Economic Research Division. Available at https://fred.stlouisfed.org/series/CPIAUCSL. [Accessed October 2020].

Federal Reserve Bank of St. Louis. (2020). "Population, Thousands, Monthly, Not Seasonally Adjusted." Economic Research Division. Available at https://fred.stlouisfed.org/series/POPTHM. [Accessed October 2020].

Federal Reserve Bank of St. Louis. (2020). "Real Disposable Personal Income, Billions of Chained 2012 Dollars, Monthly, Seasonally Adjusted Annual Rate.” Economic Research Division. Available at https://fred.stlouisfed.org/series/DSPIC96. [Accessed October 2020].

Haidacher, R.C., J.A. Craven, K.S. Huang, D.M. Smallwood, and J.R. Blaylock. (1982). "Consumer Demand for Red Meats, Poultry, and Fish." Economic Research Service, United States Department of Agriculture. Report No. AGES820818.

Haley, M. and F. Gale. (2020, February 3). African Swine Fever Shrinks Pork Production in China, Swells Demand for Imported Pork. Economic Research Service, United States Department of Agriculture. Available at https://www.ers.usda.gov/amberwaves/2020/february/african-swine-fever-shrinks-pork-production-in-chinaswells-demand-for-imported-pork/. [Accessed July 2020].

Hall, R.E., and M. Lieberman. (2005). Microeconomics: Principles and Applications. $\left(3^{\text {rd }}\right.$ ed.). Mason, Ohio: Thomson South-Western.

Huang, K.S. (1986). "U.S. Demand for Food: A Complete System of Price and Income Effects.” Economics Research Service, United States Department of Agriculture. Technical Bulletin No. 1714.

Leuthold, R.M., and E. Nwagbo. (1977). "Changes in the Retail Elasticities of Demand for Beef, Pork, and Broilers." Illinois Agricultural Economics, 17(2), 22-27.

Livestock Marketing Information Center. (2020). "Monthly Retail Meat Cuts." Available at https://www.lmic.info/. [Accessed October 2020].

Livestock Marketing Information Center. (2020). "National Weekly Boxed Beef Cuts Negotiated Sales." Available at https://www.lmic.info/. [Accessed October 2020].

Livestock Marketing Information Center. (2020). "Weekly Beef Trimmings." Available at https://www.lmic.info/. [Accessed October 2020]. 
Lusk, J.L., T.L. Marsh, T.C. Schroeder, and J.A. Fox. (2001). "Wholesale Demand for USDA Quality Graded Boxed Beef and Effects of Seasonality." Journal of Agricultural and Resource Economics, 26(1), 91-106.

Martinez, S. and K. Zering. (October 2004). Pork Quality and the Role of Market Organization. Economic Research Service, United States Department of Agriculture. Available at https://www.ers.usda.gov/webdocs/publications/41681/30327_aer835_002.pdf?v $=6686$.

National Pork Board. (2021). Fat In Pork. Available at https://www.pork.org/cooking/pork-nutrition/fat-in-pork/. [Accessed January 2021].

Nyankori, J.C.O., and G.H. Miller. (1982). "Some Evidence and Implications of Structural Change in Retail Demand for Meats." Southern Journal of Agricultural Economics, 14(2), 65-70.

Okrent, A. M., \& Alston, J. M. (2011). "Demand for food in the United States: A review of literature, evaluation of previous estimates, and presentation of new estimates of demand." Giannini Foundation of Agricultural Economics, University of California.

Parcell, J.L. (2003). “An Empirical Analysis of the Demand for Wholesale Pork Primals: Seasonality and Structural Change." Journal of Agricultural and Resource Economics, 28(2), 335-348.

Parcell, J.L. and V. Pierce. (2001) "Factors Affecting Wholesale Poultry Prices.” Journal of Agricultural and Applied Economics, 32(3), 471-478.

Pennsylvania State University Department of Statistics. "Testing and Remedial Measures for Autocorrelation.” Available at https://online.stat.psu.edu/stat501/lesson/14/14. [Accessed February 2021.]

Pork Promotion, Research, and Consumer Information Act of 1985. 7 U.S.C. § 48014819 (1985).

Russell, A. (2019, November 12). "Is A Bacon Shortage Coming?” Texas A\&M AgriLife. Available at https://today.tamu.edu/2019/11/12/is-a-bacon-shortage-coming/. [Accessed January 2021].

Saksena, M.J., A.M. Okernt, T.D. Anekwe, C. Cho, C. Dicken, A. Effland, H. Elitzak, J. Guthrie, K.S. Hamrick, J. Hyman, Y. Jo, B.H. Lin, L. Mancino, P.W. McLaughlin, I. Rahkovsky, K. Ralston, T.A. Smith, H. Stewart, J. Todd, and C. Tuttle. (2018). “America's Eating Habits: Food Away from Home.” Economic Research Service, United States Department of Agriculture.

Smallwood, D., Haidacher, R.C., and Blaylock, J.R. (1987). “A review of the research literature on meat demand." Economic Research Service, United States Department of Agriculture.

Stewart, Brandon. (2016, October 10). "Simple Linear Regression." [PowerPoint slides]. Princeton University. Available at https://scholar.princeton.edu/sites/default/files/bstewart/files/lecture5slides.pdf [Accessed February 2021.]

U.S. Meat Export Federation. (2020). "U.S. pork export primal share estimates." [Excel spreadsheet]. 
United States Meat Export Federation. (2020, March 2.) "Retaliatory Duties on U.S. Beef and Pork Products as of March 2, 2020."

USDA Agricultural Marketing Service. (Jan 2020). “A User’s Guide to USDA’s Pork Carcass Cutout."

USDA Economic Research Service. (2020). "U.S. food-away-from-home spending continued to outpace food-at-home spending in 2019." Food Expenditure Series.

USDA Foreign Agricultural Service Global Agricultural Trade System. (2020). Available at https://apps.fas.usda.gov/gats/default.aspx. [Accessed October 2020].

USDA National Agricultural Statistics Service. (2020). "Hogs - operations with inventory, Hogs - Inventory." Available at https://quickstats.nass.usda.gov/. [Accessed July 2021].

USDA National Agricultural Statistics Service. (2020). "Pork, cold storage, frozen stocks, measured in lb." Available at https://quickstats.nass.usda.gov/. [Accessed October 2020].

USDA National Agricultural Statistics Service. (2020). "Pork, slaughter, commercial production, measured in lb.” Available at https://quickstats.nass.usda.gov/. [Accessed October 2020].

Westhoff, P. (2020, October 8). "U.S.-China agricultural trade dispute and the Phase 1 deal." [PowerPoint slides]. University of Missouri Food and Agricultural Policy Research Institute. 
Appendix

Table A1. Belly Supply \& Utilization

\begin{tabular}{|c|c|c|c|c|c|c|c|}
\hline Year & Mo. & Beg. Stocks & Production & Imports & Exports & Ending Stocks & Dis \\
\hline 2010 & JAN & $56,764,000$ & $296,066,920$ & $6,779,839$ & $28,888,404$ & $53,584,000$ & $287,138,354$ \\
\hline 2010 & FEB & 00 & 7,000 & 33 & $6,696,132$ & $5,552,000$ & 802 \\
\hline 2010 & MAR & $, 552,000$ & $33,760,360$ & $17,669,413$ & $36,387,672$ & $88,762,000$ & 2,101 \\
\hline 2010 & APR & 00 & $02,512,760$ & 79 & 6,48 & 000 & 081 \\
\hline 2010 & MAY & $49,65 c$ & 265,2 & 16,9 & 7 & 000 &, 511 \\
\hline 2010 & JUN & $44,201,000$ & $299,666,120$ & $19,092,742$ & & & \\
\hline 2010 & JUL & 35,36 & $278,479,920$ & 17,7 & & & 865 \\
\hline 2010 & AUG & $21,380,000$ & $296,983,080$ & & & & \\
\hline 2010 & SEP & 00 & 00 & & & & 465 \\
\hline 2010 & OCT & 00 & 20 & 80 & 4 & 000 & 656 \\
\hline 010 & NOV & 00 & & & & & 07 \\
\hline 2010 & DEC & & & & & & \\
\hline 2011 & JAN & 50 & & & & & 109 \\
\hline 2011 & FEB & & & & & & \\
\hline 2011 & MAR & & & & & & 15 \\
\hline 2011 & APR & & & & & & \\
\hline 2011 & MAY & 00 & 20 & & & & 395 \\
\hline 2011 & JUN & & & & & & \\
\hline 2011 & JUL & & & & & & \\
\hline 2011 & AUG & & & & & & \\
\hline 2011 & SEP & & & & & & 69 \\
\hline 2011 & OCT & & & & & & 17 \\
\hline 2011 & NOV & & & & & & 35 \\
\hline 2011 & DEC & & & & & & 812 \\
\hline 2012 & JAN & & & & & & \\
\hline 2012 & FEB & & & & & & \\
\hline 2012 & MAR & & & & & & \\
\hline 2012 & APR & & 3 & & 7 & & 32 \\
\hline 2012 & MAY & & & & & & \\
\hline 2012 & JUN & & & & & & 082 \\
\hline 2012 & JUL & & & & & 962,000 & 28200104 \\
\hline 2012 & AUG & & & & & & 32 \\
\hline 2012 & SEP & & & & & 000 & ,787 \\
\hline 2012 & OCT & & & & & & \\
\hline 2012 & NOV & & 3 & 1 & 0 & 00 & 23 \\
\hline 2012 & DEC & & & & & & \\
\hline 2013 & JAN & & & 42 & 12, 然 & $36,425,000$ & 316 \\
\hline 2013 & FEB & & & & & $42,976,000$ & 2657044 \\
\hline 2013 & MAR & & & & & & $290,501,39$ \\
\hline 2013 & APR & $51,473,000$ & $317,514,880$ & 81 & $38,089,667$ & $56,352,000$ & $296,909,69$ \\
\hline 2013 & MAY & $56,352,000$ & $310,660,040$ & $20,890,860$ & $41,521,026$ & $54,829,000$ & $291,552,874$ \\
\hline
\end{tabular}


Table A1. Belly Supply \& Utilization (continued)

\begin{tabular}{|c|c|c|c|c|c|c|c|}
\hline Year & Mo. & Beg. Stocks & Production & Imports & Exports & Ending Stocks & Disappearance \\
\hline 2013 & JUN & $54,829,000$ & $274,242,680$ & $19,303,045$ & $38,508,481$ & $42,033,000$ & $267,833,244$ \\
\hline 2013 & JUL & $42,033,000$ & $301,073,080$ & $21,582,554$ & $38,030,290$ & $28,177,000$ & $298,481,344$ \\
\hline 2013 & AUG & $28,177,000$ & $317,122,240$ & $21,925,105$ & $39,968,389$ & $19,335,000$ & $307,920,956$ \\
\hline 2013 & SEP & $19,335,000$ & $301,498,440$ & $23,238,686$ & $38,793,259$ & $23,491,000$ & $281,787,867$ \\
\hline 2013 & OCT & $23,491,000$ & $354,848,400$ & $22,961,832$ & $41,685,580$ & $26,674,000$ & $332,941,653$ \\
\hline 2013 & NOV & $26,674,000$ & $333,727,640$ & $25,549,378$ & $43,288,583$ & $48,298,000$ & $294,364,435$ \\
\hline 2013 & DEC & $48,298,000$ & $337,899,440$ & $24,015,142$ & $42,094,259$ & $80,367,000$ & $287,751,323$ \\
\hline 2014 & JAN & $80,367,000$ & $341,220,520$ & $21,902,856$ & $43,895,710$ & $87,171,000$ & $312,423,666$ \\
\hline 2014 & FEB & $87,171,000$ & $301,711,120$ & $19,958,446$ & $42,269,312$ & $87,675,000$ & $278,896,254$ \\
\hline 2014 & MAR & $87,675,000$ & $303,379,840$ & $25,265,951$ & $47,665,973$ & $79,721,000$ & $288,933,818$ \\
\hline 2014 & APR & $79,721,000$ & $312,639,600$ & $24,785,291$ & $45,581,865$ & $83,579,000$ & $287,985,025$ \\
\hline 2014 & MAY & $83,579,000$ & $304,148,760$ & $24,532,664$ & $44,540,164$ & $85,888,000$ & $281,832,260$ \\
\hline 2014 & JUN & $85,888,000$ & $283,682,400$ & $22,771,156$ & $43,247,502$ & $83,936,000$ & $265,158,054$ \\
\hline 2014 & JUL & $83,936,000$ & $294,447,280$ & $24,218,498$ & $39,365,727$ & $64,644,000$ & $298,592,050$ \\
\hline 2014 & AUG & $64,644,000$ & $286,659,920$ & $23,282,911$ & $35,508,323$ & $45,562,000$ & $293,516,509$ \\
\hline 2014 & SEP & $45,562,000$ & $306,242,840$ & $23,524,560$ & $33,941,016$ & $34,311,000$ & $307,077,384$ \\
\hline 2014 & OCT & $34,311,000$ & $347,879,040$ & $26,382,473$ & $38,447,151$ & $29,006,000$ & $341,119,363$ \\
\hline 2014 & NOV & $29,006,000$ & $309,236,720$ & $22,961,611$ & $37,946,635$ & $35,894,000$ & $287,363,696$ \\
\hline 2014 & DEC & $35,894,000$ & $345,899,480$ & $26,208,559$ & $39,327,414$ & $47,455,000$ & $321,219,625$ \\
\hline 2015 & JAN & $47,455,000$ & $344,296,200$ & $23,808,241$ & $35,769,906$ & $53,507,000$ & $326,282,535$ \\
\hline 2015 & FEB & $53,507,000$ & $318,234,720$ & $22,254,333$ & $39,595,802$ & $67,794,000$ & $286,606,252$ \\
\hline 2015 & MAR & $67,794,000$ & $345,490,480$ & $26,651,093$ & $43,952,428$ & $68,297,000$ & $327,686,145$ \\
\hline 2015 & APR & $68,297,000$ & $338,144,840$ & $24,196,409$ & $47,829,819$ & $70,412,000$ & $312,396,430$ \\
\hline 2015 & MAY & $70,412,000$ & $304,606,840$ & $22,091,566$ & $42,818,623$ & $64,805,000$ & $289,486,783$ \\
\hline 2015 & JUN & $64,805,000$ & $326,529,240$ & $25,533,034$ & $37,697,799$ & $44,432,000$ & $334,737,475$ \\
\hline 2015 & JUL & $44,432,000$ & $322,766,440$ & $23,286,822$ & $38,943,242$ & $23,634,000$ & $327,908,020$ \\
\hline 2015 & AUG & $23,634,000$ & $318,872,760$ & $23,488,766$ & $38,185,636$ & $13,738,000$ & $314,071,890$ \\
\hline 2015 & SEP & $13,738,000$ & $333,073,240$ & $24,785,083$ & $42,372,694$ & $10,872,000$ & $318,351,629$ \\
\hline 2015 & OCT & $10,872,000$ & $354,881,120$ & $25,928,774$ & $40,422,252$ & $17,853,000$ & $333,406,642$ \\
\hline 2015 & NOV & $17,853,000$ & $340,418,880$ & $25,939,856$ & $41,355,220$ & $41,160,000$ & $301,696,516$ \\
\hline 2015 & DEC & $41,160,000$ & $361,097,920$ & $26,457,061$ & $40,840,465$ & $53,392,000$ & $334,482,516$ \\
\hline 2016 & JAN & $53,392,000$ & $340,975,120$ & $27,183,141$ & $37,895,408$ & $60,698,000$ & $322,956,854$ \\
\hline 2016 & FEB & $60,698,000$ & $327,347,240$ & $24,887,652$ & $38,369,539$ & $61,433,000$ & $313,130,353$ \\
\hline 2016 & MAR & $61,433,000$ & $350,954,720$ & $28,232,519$ & $46,183,383$ & $65,028,000$ & $329,408,856$ \\
\hline 2016 & APR & $65,028,000$ & $327,232,720$ & $22,176,492$ & $40,838,746$ & $72,592,000$ & $301,006,465$ \\
\hline 2016 & MAY & $72,592,000$ & $318,856,400$ & $24,068,326$ & $42,753,745$ & $77,683,000$ & $295,079,981$ \\
\hline 2016 & JUN & $77,683,000$ & $329,408,600$ & $21,872,173$ & $40,747,721$ & $62,921,000$ & $325,295,052$ \\
\hline 2016 & JUL & $62,921,000$ & $298,488,200$ & $23,169,983$ & $37,657,236$ & $50,733,000$ & $296,188,947$ \\
\hline 2016 & AUG & $50,733,000$ & $351,674,560$ & $22,482,194$ & $40,231,677$ & $32,053,000$ & $352,605,077$ \\
\hline 2016 & SEP & $32,053,000$ & $347,862,680$ & $21,638,345$ & $40,006,916$ & $25,084,000$ & $336,463,109$ \\
\hline 2016 & OCT & $25,084,000$ & $359,641,880$ & $25,146,476$ & $43,734,911$ & $20,386,000$ & $345,751,446$ \\
\hline 2016 & NOV & $20,386,000$ & $366,513,080$ & $25,132,309$ & $48,146,063$ & $18,526,000$ & $345,359,326$ \\
\hline 2016 & DEC & $18,526,000$ & $361,408,760$ & $24,011,736$ & $45,170,691$ & $17,986,000$ & $340,789,805$ \\
\hline 2017 & JAN & $17,986,000$ & $352,525,280$ & $21,332,559$ & $43,325,866$ & $13,995,000$ & $334,522,973$ \\
\hline 2017 & FEB & $13,995,000$ & $325,171,360$ & $22,416,564$ & $42,952,870$ & $16,153,000$ & $302,477,055$ \\
\hline 2017 & MAR & $16,153,000$ & $370,979,360$ & $26,723,639$ & $50,515,449$ & $20,570,000$ & $342,770,550$ \\
\hline 2017 & APR & $20,570,000$ & $325,269,520$ & $25,661,643$ & $45,234,382$ & $33,536,000$ & $292,730,781$ \\
\hline
\end{tabular}


Table A1. Belly Supply \& Utilization (continued)

\begin{tabular}{|c|c|c|c|c|c|c|c|}
\hline Year & Mo. & Beg. Stocks & Production & Imports & Exports & Ending Stocks & Disappearance \\
\hline 2017 & MAY & $33,536,000$ & $342,889,240$ & $23,221,572$ & $48,719,789$ & $31,589,000$ & $319,338,023$ \\
\hline 2017 & JUN & $31,589,000$ & $335,903,520$ & $22,010,732$ & $42,951,152$ & $22,291,000$ & $324,261,101$ \\
\hline 2017 & JUL & $22,291,000$ & $305,097,640$ & $21,976,090$ & $40,095,272$ & $17,602,000$ & $291,667,459$ \\
\hline 2017 & AUG & $17,602,000$ & $361,637,800$ & $22,359,125$ & $42,362,833$ & $19,213,000$ & $340,023,093$ \\
\hline 2017 & SEP & $19,213,000$ & $354,177,640$ & $22,498,812$ & $41,564,168$ & $20,897,000$ & $333,428,284$ \\
\hline 2017 & OCT & $20,897,000$ & $378,979,400$ & $21,971,747$ & $48,010,757$ & $32,268,000$ & $341,569,390$ \\
\hline 2017 & NOV & $32,268,000$ & $367,249,280$ & $19,775,378$ & $50,368,246$ & $35,164,000$ & $333,760,411$ \\
\hline 2017 & DEC & $35,164,000$ & $365,646,000$ & $20,770,116$ & $48,499,814$ & $39,620,000$ & $333,460,302$ \\
\hline 2018 & JAN & $39,620,000$ & $374,660,360$ & $21,607,192$ & $46,070,315$ & $43,810,000$ & $346,007,237$ \\
\hline 2018 & FEB & $43,810,000$ & $336,705,160$ & $21,964,992$ & $47,637,441$ & $49,012,000$ & $305,830,711$ \\
\hline 2018 & MAR & $49,012,000$ & $375,756,480$ & $21,437,227$ & $53,331,360$ & $59,202,000$ & $333,672,348$ \\
\hline 2018 & APR & $59,202,000$ & $350,414,840$ & $20,863,061$ & $52,169,512$ & $64,563,000$ & $313,747,389$ \\
\hline 2018 & MAY & $64,563,000$ & $355,731,840$ & $20,369,687$ & $49,304,701$ & $61,234,000$ & $330,125,826$ \\
\hline 2018 & JUN & $61,234,000$ & $328,606,960$ & $18,918,033$ & $45,481,684$ & $53,279,000$ & $309,998,309$ \\
\hline 2018 & JUL & $53,279,000$ & $324,827,800$ & $19,292,704$ & $42,936,132$ & $38,556,000$ & $315,907,372$ \\
\hline 2018 & AUG & $38,556,000$ & $378,946,680$ & $18,722,129$ & $43,139,459$ & $34,805,000$ & $358,280,350$ \\
\hline 2018 & SEP & $34,805,000$ & $329,310,440$ & $18,137,390$ & $42,312,259$ & $30,354,000$ & $309,586,572$ \\
\hline 2018 & OCT & $30,354,000$ & $400,901,800$ & $19,470,442$ & $47,131,577$ & $26,690,000$ & $376,904,665$ \\
\hline 2018 & NOV & $26,690,000$ & $384,132,800$ & $20,043,576$ & $49,903,497$ & $36,859,000$ & $344,103,879$ \\
\hline 2018 & DEC & $36,859,000$ & $365,171,560$ & $20,076,633$ & $52,364,313$ & $42,251,000$ & $327,491,880$ \\
\hline 2019 & JAN & $42,251,000$ & $388,320,960$ & $20,129,088$ & $45,679,585$ & $53,736,000$ & $351,285,463$ \\
\hline 2019 & FEB & $53,736,000$ & $354,603,000$ & $19,418,623$ & $43,919,294$ & $53,771,000$ & $330,067,329$ \\
\hline 2019 & MAR & $53,771,000$ & $375,821,920$ & $22,313,411$ & $51,239,046$ & $58,783,000$ & $341,884,285$ \\
\hline 2019 & APR & $58,783,000$ & $371,175,680$ & $18,461,595$ & $50,275,617$ & $61,110,000$ & $337,034,658$ \\
\hline 2019 & MAY & $61,110,000$ & $362,962,960$ & $17,535,027$ & $50,911,377$ & $64,124,000$ & $326,572,610$ \\
\hline 2019 & JUN & $64,124,000$ & $348,075,360$ & $17,412,336$ & $50,527,404$ & $56,468,000$ & $322,616,291$ \\
\hline 2019 & JUL & $56,468,000$ & $361,670,520$ & $18,091,697$ & $57,034,565$ & $52,647,000$ & $326,548,653$ \\
\hline 2019 & AUG & $52,647,000$ & $369,425,160$ & $17,433,330$ & $53,030,517$ & $45,723,000$ & $340,751,973$ \\
\hline 2019 & SEP & $45,723,000$ & $366,005,920$ & $16,897,490$ & $47,771,336$ & $40,543,000$ & $340,312,074$ \\
\hline 2019 & OCT & $40,543,000$ & $426,374,320$ & $18,189,038$ & $56,032,208$ & $45,920,000$ & $383,154,150$ \\
\hline 2019 & NOV & $45,920,000$ & $397,351,680$ & $17,360,571$ & $65,977,172$ & $54,416,000$ & $340,239,079$ \\
\hline 2019 & DEC & $54,416,000$ & $399,674,800$ & $17,632,386$ & $71,552,227$ & $68,015,000$ & $332,155,960$ \\
\hline 2020 & JAN & $68,015,000$ & $417,719,880$ & $18,086,468$ & $68,940,216$ & $70,872,000$ & $364,009,132$ \\
\hline 2020 & FEB & $70,872,000$ & $377,294,320$ & $17,202,242$ & $68,903,673$ & $74,270,000$ & $322,194,889$ \\
\hline 2020 & MAR & $74,270,000$ & $419,879,400$ & $17,585,757$ & $73,582,054$ & $78,157,000$ & $359,996,103$ \\
\hline 2020 & APR & $78,157,000$ & $332,238,880$ & $12,668,043$ & $65,924,265$ & $80,728,000$ & $276,411,659$ \\
\hline 2020 & MAY & $80,728,000$ & $307,502,560$ & $17,545,686$ & $62,810,939$ & $60,322,000$ & $282,643,307$ \\
\hline 2020 & JUN & $60,322,000$ & $392,705,440$ & $17,307,603$ & $48,172,059$ & $53,840,000$ & $368,322,985$ \\
\hline 2020 & JUL & $53,840,000$ & $388,010,120$ & $16,515,661$ & $51,299,860$ & $42,374,000$ & $364,691,921$ \\
\hline 2020 & AUG & $42,374,000$ & $383,020,320$ & $17,776,916$ & $49,702,173$ & $30,533,000$ & $362,936,063$ \\
\hline
\end{tabular}


Table A2. Butt Supply \& Utilization

\begin{tabular}{|c|c|c|c|c|c|c|c|}
\hline Year & Mo. & Beg. Stocks & Production & Imports & Exports & Ending Stocks & Disappearan \\
\hline 2010 & JAN & $20,066,000$ & $182,960,670$ & $4,643,995$ & $32,948,815$ & $21,868,000$ & 152853 \\
\hline 2010 & FEB & 000 & $7,683,250$ & 67 & $1,971,118$ & $3,973,000$ & 4,49 \\
\hline 2010 & MAR & 23,97 & 206,254 & 29,007 & $5,619,564$ & $, 202,000$ &, 553 \\
\hline 2010 & APR & $25,202,000$ & $186,944,010$ & & 8,119 & $9,210,000$ & ,796 \\
\hline 2010 & MAY & 19,2 & 163, & & 81 & 00 & 5,507 \\
\hline 2010 & JUN & $14,028,000$ & 185 & 80 & 902 & $8,636,000$ & 845 \\
\hline 2010 & JUL & 36,000 & 20 & 14 & 55 & & 078 \\
\hline 2010 & AUG & & & & 04 & & 413 \\
\hline 2010 & SEP & 00 & 190, & & & & 44 \\
\hline 2010 & OCT & 00 & 70 & & 85 & 000 & 111 \\
\hline 2010 & NOV & 00 & 2 & & & & 60 \\
\hline 2010 & DEC & 00 & & & & & \\
\hline 2011 & JAN & 16 , & 20 & 9 & 2 & 00 & 827 \\
\hline 2011 & FEB & & & & & & \\
\hline 2011 & MAR & 00 & 0 & & 5 & 00 & 39 \\
\hline 2011 & APR & & & & & & \\
\hline 2011 & MAY & 0 & & & & & 337 \\
\hline 2011 & JUN & & & & & & \\
\hline 2011 & JUL & & & & & & \\
\hline 2011 & AUG & & & & & & \\
\hline 2011 & SEP & & & & & & \\
\hline 2011 & OCT & & & & & & \\
\hline 2011 & NOV & & & & & & \\
\hline 2011 & DEC & & & & & & \\
\hline 2012 & JAN & & & & & & \\
\hline 2012 & FEB & & & & & & \\
\hline 2012 & MAR & & & & & 00 &, 133 \\
\hline 2012 & APR & & & & & & ,94 \\
\hline 2012 & MAY & & & & & & \\
\hline 2012 & JUN & & & & & & 92 \\
\hline 2012 & JUL & & & & & & \\
\hline 2012 & AUG & & & & & & 70 \\
\hline 2012 & SEP & & & & & & \\
\hline 2012 & OCT & & & & & & 617 \\
\hline 2012 & NOV & & & & & & 33 \\
\hline 2012 & DEC & & & & & 0 & o \\
\hline 2013 & JAN & & & & & & \\
\hline 2013 & FEB & & & & & & \\
\hline 2013 & MAR & & & & & & \\
\hline 2013 & APR & & & & & 000 & \\
\hline 2013 & MAY & & & & & & \\
\hline 2013 & JUN & & $169,473,930$ & & $38,288,170$ & $16,165,000$ & $141,692,631$ \\
\hline & & & & & & & \\
\hline 2015 & AUU & $15,639,000$ & $195,972,240$ & $4,945,917$ & $38,530,246$ & $16,737,000$ & $161,289,912$ \\
\hline
\end{tabular}


Table A2. Butt Supply \& Utilization (continued)

\begin{tabular}{|c|c|c|c|c|c|c|c|}
\hline Year & Mo. & Beg. Stocks & Production & Imports & Exports & Ending Stocks & Disappearance \\
\hline 2013 & SEP & $16,737,000$ & $186,317,190$ & $5,232,613$ & $37,776,704$ & $17,756,000$ & $152,754,099$ \\
\hline 2013 & OCT & $17,756,000$ & $219,285,900$ & $5,241,810$ & $41,783,646$ & $19,058,000$ & $181,442,064$ \\
\hline 2013 & NOV & $19,058,000$ & $206,233,890$ & $5,366,446$ & $44,606,185$ & $19,887,000$ & $166,165,152$ \\
\hline 2013 & DEC & $19,887,000$ & $208,811,940$ & $5,035,583$ & $45,390,648$ & $17,979,000$ & $170,364,875$ \\
\hline 2014 & JAN & $17,979,000$ & $210,864,270$ & $4,882,751$ & $44,764,263$ & $21,179,000$ & $167,782,758$ \\
\hline 2014 & FEB & $21,179,000$ & $186,448,620$ & $4,331,349$ & $43,440,738$ & $26,094,000$ & $142,424,231$ \\
\hline 2014 & MAR & $26,094,000$ & $187,479,840$ & $5,300,324$ & $49,618,215$ & $20,163,000$ & $149,092,949$ \\
\hline 2014 & APR & $20,163,000$ & $193,202,100$ & $5,544,036$ & $45,158,425$ & $19,771,000$ & $153,979,711$ \\
\hline 2014 & MAY & $19,771,000$ & $187,955,010$ & $6,154,861$ & $43,787,014$ & $21,732,000$ & $148,361,856$ \\
\hline 2014 & JUN & $21,732,000$ & $175,307,400$ & $5,584,029$ & $43,483,923$ & $19,999,000$ & $139,140,506$ \\
\hline 2014 & JUL & $19,999,000$ & $181,959,780$ & $5,403,247$ & $41,496,199$ & $21,116,000$ & $144,749,828$ \\
\hline 2014 & AUG & $21,116,000$ & $177,147,420$ & $6,005,947$ & $37,777,420$ & $23,778,000$ & $142,713,948$ \\
\hline 2014 & SEP & $23,778,000$ & $189,249,090$ & $6,564,737$ & $37,313,940$ & $22,035,000$ & $160,242,886$ \\
\hline 2014 & OCT & $22,035,000$ & $214,979,040$ & $7,251,010$ & $41,321,474$ & $23,458,000$ & $179,485,576$ \\
\hline 2014 & NOV & $23,458,000$ & $191,099,220$ & $6,412,794$ & $38,923,110$ & $22,549,000$ & $159,497,904$ \\
\hline 2014 & DEC & $22,549,000$ & $213,755,730$ & $7,532,777$ & $41,618,876$ & $19,567,000$ & $182,651,631$ \\
\hline 2015 & JAN & $19,567,000$ & $212,764,950$ & $6,562,991$ & $36,688,648$ & $25,104,000$ & $177,102,293$ \\
\hline 2015 & FEB & $25,104,000$ & $196,659,720$ & $6,091,504$ & $39,336,000$ & $35,641,000$ & $152,878,224$ \\
\hline 2015 & MAR & $35,641,000$ & $213,502,980$ & $7,579,817$ & $46,786,210$ & $33,656,000$ & $176,281,587$ \\
\hline 2015 & APR & $33,656,000$ & $208,963,590$ & $6,506,739$ & $47,137,204$ & $25,234,000$ & $176,755,125$ \\
\hline 2015 & MAY & $25,234,000$ & $188,238,090$ & $5,770,944$ & $45,150,933$ & $20,177,000$ & $153,915,101$ \\
\hline 2015 & JUN & $20,177,000$ & $201,785,490$ & $6,955,069$ & $44,508,568$ & $22,018,000$ & $162,390,991$ \\
\hline 2015 & JUL & $22,018,000$ & $199,460,190$ & $6,182,318$ & $41,699,576$ & $22,876,000$ & $163,084,932$ \\
\hline 2015 & AUG & $22,876,000$ & $197,054,010$ & $6,535,468$ & $39,113,083$ & $20,053,000$ & $167,299,395$ \\
\hline 2015 & SEP & $20,053,000$ & $205,829,490$ & $6,457,403$ & $40,252,464$ & $18,793,000$ & $173,294,429$ \\
\hline 2015 & OCT & $18,793,000$ & $219,306,120$ & $6,894,533$ & $42,802,578$ & $19,648,000$ & $182,543,075$ \\
\hline 2015 & NOV & $19,648,000$ & $210,368,880$ & $7,066,967$ & $45,703,394$ & $18,897,000$ & $172,483,453$ \\
\hline 2015 & DEC & $18,897,000$ & $223,147,920$ & $7,528,093$ & $45,420,242$ & $15,029,000$ & $189,123,770$ \\
\hline 2016 & JAN & $15,029,000$ & $210,712,620$ & $6,914,729$ & $40,314,737$ & $23,288,000$ & $169,053,612$ \\
\hline 2016 & FEB & $23,288,000$ & $202,290,990$ & $6,799,555$ & $39,650,044$ & $25,586,000$ & $167,142,501$ \\
\hline 2016 & MAR & $25,586,000$ & $216,879,720$ & $7,491,516$ & $44,957,575$ & $21,925,000$ & $183,074,661$ \\
\hline 2016 & APR & $21,925,000$ & $202,220,220$ & $6,507,384$ & $44,582,387$ & $19,172,000$ & $166,898,217$ \\
\hline 2016 & MAY & $19,172,000$ & $197,043,900$ & $6,788,588$ & $49,153,000$ & $16,340,000$ & $157,511,488$ \\
\hline 2016 & JUN & $16,340,000$ & $203,564,850$ & $6,619,047$ & $44,721,587$ & $15,057,000$ & $166,745,310$ \\
\hline 2016 & JUL & $15,057,000$ & $184,456,950$ & $6,830,841$ & $43,534,345$ & $16,197,000$ & $146,613,446$ \\
\hline 2016 & AUG & $16,197,000$ & $217,324,560$ & $6,717,668$ & $42,839,262$ & $15,310,000$ & $182,089,966$ \\
\hline 2016 & SEP & $15,310,000$ & $214,968,930$ & $6,398,176$ & $42,745,279$ & $18,295,000$ & $175,636,828$ \\
\hline 2016 & OCT & $18,295,000$ & $222,248,130$ & & $45,715,316$ & $19,351,000$ & $182,359,958$ \\
\hline 2016 & NOV & $19,351,000$ & $226,494,330$ & $7,199,428$ & $51,969,919$ & $21,654,000$ & $179,420,839$ \\
\hline 2016 & DEC & $21,654,000$ & $223,340,010$ & $6,666,626$ & $52,221,078$ & $18,075,000$ & $181,364,558$ \\
\hline 2017 & JAN & $18,075,000$ & $217,850,280$ & $6,646,938$ & $47,505,054$ & $23,243,000$ & $171,824,164$ \\
\hline 2017 & FEB & $23,243,000$ & $200,946,360$ & $6,435,052$ & $45,822,410$ & $22,052,000$ & $162,750,001$ \\
\hline 2017 & MAR & $22,052,000$ & $229,254,360$ & $7,817,045$ & $52,674,530$ & $21,925,000$ & $184,523,875$ \\
\hline 2017 & APR & $21,925,000$ & $201,007,020$ & $7,244,403$ & $46,581,689$ & $21,264,000$ & $162,330,733$ \\
\hline 2017 & MAY & $21,264,000$ & $211,895,490$ & $6,961,290$ & $52,814,883$ & $19,862,000$ & $167,443,897$ \\
\hline 2017 & JUN & $19,862,000$ & $207,578,520$ & $7,342,581$ & $45,859,155$ & $15,057,000$ & $173,866,947$ \\
\hline 2017 & JUL & $15,057,000$ & $188,541,390$ & $7,076,843$ & $39,096,539$ & $14,502,000$ & $157,076,694$ \\
\hline
\end{tabular}


Table A2. Butt Supply \& Utilization (continued)

\begin{tabular}{|c|c|c|c|c|c|c|c|}
\hline Year & Mo. & Beg. Stocks & Production & Imports & Exports & Ending Stocks & Disappearance \\
\hline 2017 & AUG & $14,502,000$ & $223,481,550$ & $7,372,996$ & $41,804,533$ & $16,308,000$ & $187,244,013$ \\
\hline 2017 & SEP & $16,308,000$ & $218,871,390$ & $6,876,438$ & $43,084,198$ & $17,247,000$ & $181,724,630$ \\
\hline 2017 & OCT & $17,247,000$ & $234,198,150$ & $7,724,920$ & $49,521,696$ & $21,249,000$ & $188,399,373$ \\
\hline 2017 & NOV & $21,249,000$ & $226,949,280$ & $7,473,576$ & $54,053,176$ & $25,799,000$ & $175,819,681$ \\
\hline 2017 & DEC & $25,799,000$ & $225,958,500$ & $7,798,397$ & $53,078,085$ & $23,883,000$ & $182,594,812$ \\
\hline 2018 & JAN & $23,883,000$ & $231,529,110$ & $7,936,839$ & $49,394,546$ & $25,477,000$ & $188,477,403$ \\
\hline 2018 & FEB & $25,477,000$ & $208,073,910$ & $7,270,261$ & $49,246,540$ & $22,503,000$ & $169,071,630$ \\
\hline 2018 & MAR & $22,503,000$ & $232,206,480$ & $8,079,208$ & $52,472,719$ & $20,629,000$ & $189,686,969$ \\
\hline 2018 & APR & $20,629,000$ & $216,546,090$ & $8,289,400$ & $55,460,523$ & $20,904,000$ & $169,099,968$ \\
\hline 2018 & MAY & $20,904,000$ & $219,831,840$ & $7,474,182$ & $51,944,652$ & $15,313,000$ & $180,952,369$ \\
\hline 2018 & JUN & $15,313,000$ & $203,069,460$ & $6,642,809$ & $44,755,120$ & $15,734,000$ & $164,536,148$ \\
\hline 2018 & JUL & $15,734,000$ & $200,734,050$ & $6,969,409$ & $42,063,188$ & $13,218,000$ & $168,156,271$ \\
\hline 2018 & AUG & $13,218,000$ & $234,177,930$ & $6,562,170$ & $44,079,699$ & $11,498,000$ & $198,380,400$ \\
\hline 2018 & SEP & $11,498,000$ & $203,504,190$ & $6,111,775$ & $43,496,071$ & $13,282,000$ & $164,335,893$ \\
\hline 2018 & OCT & $13,282,000$ & $247,745,550$ & $6,387,822$ & $50,517,850$ & $17,014,000$ & $199,883,522$ \\
\hline 2018 & NOV & $17,014,000$ & $237,382,800$ & $6,386,691$ & $50,306,715$ & $17,623,000$ & $192,853,776$ \\
\hline 2018 & DEC & $17,623,000$ & $225,665,310$ & $6,424,746$ & $50,604,036$ & $16,749,000$ & $182,360,020$ \\
\hline 2019 & JAN & $16,749,000$ & $239,970,960$ & $6,999,951$ & $47,726,664$ & $20,527,000$ & $195,466,248$ \\
\hline 2019 & FEB & $20,527,000$ & $219,134,250$ & $6,767,355$ & $44,859,254$ & $25,290,000$ & $176,279,352$ \\
\hline 2019 & MAR & $25,290,000$ & $232,246,920$ & $7,078,121$ & $51,112,703$ & $26,271,000$ & $187,231,338$ \\
\hline 2019 & APR & $26,271,000$ & $229,375,680$ & $6,115,084$ & $52,443,640$ & $21,164,000$ & $188,154,123$ \\
\hline 2019 & MAY & $21,164,000$ & $224,300,460$ & $5,800,670$ & $49,738,013$ & $21,189,000$ & $180,338,117$ \\
\hline 2019 & JUN & $21,189,000$ & $215,100,360$ & $5,514,458$ & $50,036,397$ & $17,218,000$ & $174,549,421$ \\
\hline 2019 & JUL & $17,218,000$ & $223,501,770$ & $5,865,029$ & $54,938,229$ & $18,363,000$ & $173,283,570$ \\
\hline 2019 & AUG & $18,363,000$ & $228,293,910$ & & $50,955,189$ & $16,200,000$ & $185,307,893$ \\
\hline 2019 & SEP & $16,200,000$ & $226,180,920$ & $5,535,115$ & $46,818,876$ & $15,494,000$ & $185,603,160$ \\
\hline 2019 & OCT & $15,494,000$ & $263,486,820$ & $6,132,170$ & $50,912,933$ & $20,580,000$ & $213,620,057$ \\
\hline 2019 & NOV & $20,580,000$ & $245,551,680$ & $5,519,176$ & $61,655,834$ & $25,933,000$ & $184,062,022$ \\
\hline 2019 & DEC & $25,933,000$ & $246,987,300$ & $4,993,927$ & $67,852,682$ & $20,702,000$ & $189,359,545$ \\
\hline 2020 & JAN & $20,702,000$ & $258,138,630$ & $5,172,119$ & $67,202,430$ & $26,028,000$ & $190,782,320$ \\
\hline 2020 & FEB & $26,028,000$ & $233,156,820$ & $4,785,790$ & $65,167,426$ & $26,892,000$ & $171,911,184$ \\
\hline 2020 & MAR & $26,892,000$ & $259,473,150$ & $5,062,439$ & $68,226,321$ & $27,615,000$ & $195,586,268$ \\
\hline 2020 & APR & $27,615,000$ & $205,313,880$ & $4,491,670$ & $60,655,969$ & $26,374,000$ & $150,390,581$ \\
\hline 2020 & MAY & $26,374,000$ & $190,027,560$ & $6,578,860$ & $58,686,329$ & $17,152,000$ & $147,142,091$ \\
\hline 2020 & JUN & $17,152,000$ & $242,680,440$ & $6,542,604$ & $54,560,620$ & $13,161,000$ & $198,653,425$ \\
\hline 2020 & JUL & $13,161,000$ & $239,778,870$ & $6,035,595$ & $58,739,396$ & $13,557,000$ & $186,679,069$ \\
\hline 2020 & AUG & $13,557,000$ & $236,695,320$ & $6,400,774$ & $54,786,619$ & $14,520,000$ & $187,346,475$ \\
\hline
\end{tabular}


Table A3. Ham Supply \& Utilization

\begin{tabular}{|c|c|c|c|c|c|c|c|}
\hline Year & Mo. & Beg. Stocks & Production & Imports & Exports & Ending Stocks & \\
\hline 2010 & JAN & $0,419,000$ & $445,367,170$ & $1,569,64$ & $, 344,334$ & $72,736,000$ & 60075 \\
\hline 2010 & FEB & & & & 20 & & \\
\hline 2010 & MAR & 00 & $2,068,610$ & 69 & 45 & $1,579,000$ & . \\
\hline 2010 & APR & 00 & & & & & \\
\hline 2010 & MAY & & & & & & \\
\hline 2010 & JUN & 00 & 70 & O & & 000 & \\
\hline 10 & JUL & & & & & & \\
\hline 2010 & AUG & 1 & & & & & \\
\hline 2010 & SEP & & & & & & \\
\hline 2010 & OCT & 1 & & & & & \\
\hline 0 & NOV & & & & & & \\
\hline 2010 & DEC & & & & & & \\
\hline 2011 & JAN & & & & & & \\
\hline 011 & FEB & & & & & & \\
\hline 2011 & MAR & 0 & & & & & \\
\hline 2011 & APR & & & & & & \\
\hline 2011 & MAY & & & & & & \\
\hline 20 & JUN & & & & & & \\
\hline 2011 & JUL & & & & & & \\
\hline 2011 & AUG & & & & & & \\
\hline 2011 & SEP & & & & & & \\
\hline 11 & OCT & & & & & & \\
\hline 2011 & NOV & & & & & & \\
\hline 1 & DEC & & & & & & \\
\hline 2012 & $N$ & & & & & & \\
\hline 2012 & B & & & & & & \\
\hline 2012 & MAR & & & & & & \\
\hline 2012 & APR & & & & & & \\
\hline 2 & Y & & & & & & \\
\hline 2012 & JUN & & & & & & \\
\hline 20 & $\mathrm{~L}$ & & & & & & \\
\hline 2012 & AUG & & & & & & \\
\hline 20 & & & & & & & \\
\hline 2012 & OCT & & & & & & \\
\hline 2012 & NOV & & & & & & \\
\hline 26 & DEC & & & & & & \\
\hline 2013 & JAN & & & & & & \\
\hline 20 & & & & & & & \\
\hline 2013 & MAR & & & & & & \\
\hline 20 & & & & & & & \\
\hline & & & & & & & \\
\hline 2013 & JUN & & & & & & ח \\
\hline & & & & & & & \\
\hline 2015 & RUS & $180,677,000$ & $477,040,240$ & $25,162,160$ & $96,735,725$ & $207,006,000$ & 79,137 \\
\hline
\end{tabular}


Table A3. Ham Supply \& Utilization (continued)

\begin{tabular}{|c|c|c|c|c|c|c|c|}
\hline Year & Mo. & Beg. Stocks & Production & Imports & Exports & Ending Stocks & Disappearance \\
\hline 2013 & SEP & $207,006,000$ & $453,537,690$ & $23,457,094$ & $95,561,589$ & $221,633,000$ & $366,806,195$ \\
\hline 2013 & OCT & $221,633,000$ & $533,790,900$ & $24,107,227$ & $104,959,971$ & $192,947,000$ & $481,624,156$ \\
\hline 2013 & NOV & $192,947,000$ & $502,019,390$ & $25,518,394$ & $112,572,824$ & $116,076,000$ & $491,835,961$ \\
\hline 2013 & DEC & $116,076,000$ & $508,294,940$ & $22,660,151$ & $113,698,825$ & $76,773,000$ & $456,559,267$ \\
\hline 2014 & JAN & $76,773,000$ & $513,290,770$ & $19,360,606$ & $108,371,167$ & $106,183,000$ & $394,870,209$ \\
\hline 2014 & FEB & $106,183,000$ & $453,857,620$ & $17,810,811$ & $105,394,393$ & $117,464,000$ & $354,993,038$ \\
\hline 2014 & MAR & $117,464,000$ & $456,367,840$ & $23,786,956$ & $122,484,438$ & $89,452,000$ & $385,682,358$ \\
\hline 2014 & APR & $89,452,000$ & $470,297,100$ & $22,905,416$ & $111,892,376$ & $81,785,000$ & $388,977,139$ \\
\hline 2014 & MAY & $81,785,000$ & $457,524,510$ & $23,964,743$ & $108,286,402$ & $109,999,000$ & $344,988,851$ \\
\hline 2014 & JUN & $109,999,000$ & $426,737,400$ & $22,841,640$ & $107,519,309$ & $126,493,000$ & $325,565,731$ \\
\hline 2014 & JUL & $126,493,000$ & $442,930,780$ & $25,306,473$ & $102,068,121$ & $148,905,000$ & $343,757,132$ \\
\hline 2014 & AUG & $148,905,000$ & $431,216,420$ & $25,220,377$ & $93,210,997$ & $179,483,000$ & $332,647,800$ \\
\hline 2014 & SEP & $179,483,000$ & $460,674,590$ & $35,471,761$ & $93,699,749$ & $194,077,000$ & $387,852,601$ \\
\hline 2014 & OCT & $194,077,000$ & $523,307,040$ & $43,807,495$ & $103,779,405$ & $162,035,000$ & $495,377,130$ \\
\hline 2014 & NOV & $162,035,000$ & $465,178,220$ & $33,120,406$ & $99,043,750$ & $96,397,000$ & $464,892,876$ \\
\hline 2014 & DEC & $96,397,000$ & $520,329,230$ & $37,101,934$ & $105,836,600$ & $66,349,000$ & $481,642,564$ \\
\hline 2015 & JAN & $66,349,000$ & $517,917,450$ & $33,283,036$ & $93,270,021$ & $110,404,000$ & $413,875,464$ \\
\hline 2015 & FEB & $110,404,000$ & $478,713,720$ & $29,175,052$ & $100,762,252$ & $127,712,000$ & $389,818,520$ \\
\hline 2015 & MAR & $127,712,000$ & $519,713,980$ & $33,216,530$ & $118,019,784$ & $98,031,000$ & $464,591,725$ \\
\hline 2015 & APR & $98,031,000$ & $508,664,090$ & $27,260,773$ & $117,415,389$ & $136,222,000$ & $380,318,473$ \\
\hline 2015 & MAY & $136,222,000$ & $458,213,590$ & $27,602,879$ & $110,210,913$ & $158,882,000$ & $352,945,556$ \\
\hline 2015 & JUN & $158,882,000$ & $491,190,990$ & $32,194,114$ & $108,286,550$ & $180,473,000$ & $393,507,555$ \\
\hline 2015 & JUL & $180,473,000$ & $485,530,690$ & $28,133,591$ & $100,747,166$ & $205,549,000$ & $387,841,116$ \\
\hline 2015 & AUG & $205,549,000$ & $479,673,510$ & $32,182,414$ & $93,761,337$ & $236,531,000$ & $387,112,587$ \\
\hline 2015 & SEP & $236,531,000$ & $501,034,990$ & $31,303,094$ & $98,464,197$ & $247,145,000$ & $423,259,888$ \\
\hline 2015 & OCT & $247,145,000$ & $533,840,120$ & $34,317,962$ & $104,653,512$ & $196,460,000$ & $514,189,569$ \\
\hline 2015 & NOV & $196,460,000$ & $512,084,880$ & $34,319,838$ & $111,382,201$ & $109,042,000$ & $522,440,517$ \\
\hline 2015 & DEC & $109,042,000$ & $543,191,920$ & $35,495,125$ & $110,006,999$ & $67,813,000$ & $509,909,045$ \\
\hline 2016 & JAN & $67,813,000$ & $512,921,620$ & $33,242,397$ & $95,544,687$ & $111,142,000$ & $407,290,331$ \\
\hline 2016 & FEB & $111,142,000$ & $492,421,490$ & $31,698,727$ & $94,901,768$ & $115,780,000$ & $424,580,448$ \\
\hline 2016 & MAR & $115,780,000$ & $527,933,720$ & $29,245,404$ & $109,713,753$ & $96,511,000$ & $466,734,371$ \\
\hline 2016 & APR & $96,511,000$ & $492,249,220$ & $24,880,127$ & $108,690,933$ & $130,217,000$ & $374,732,414$ \\
\hline 2016 & MAY & $130,217,000$ & $479,648,900$ & $28,402,822$ & $118,664,687$ & $144,060,000$ & $375,544,035$ \\
\hline 2016 & JUN & $144,060,000$ & $495,522,350$ & $25,643,831$ & $109,018,669$ & $166,451,000$ & $389,756,513$ \\
\hline 2016 & JUL & $166,451,000$ & $449,009,450$ & $29,605,048$ & $105,658,978$ & $188,441,000$ & $350,965,521$ \\
\hline 2016 & AUG & $188,441,000$ & $529,016,560$ & $30,362,389$ & $105,009,853$ & $226,070,000$ & $416,740,095$ \\
\hline 2016 & SEP & $226,070,000$ & $523,282,430$ & $28,436,651$ & $105,743,015$ & $248,972,000$ & $423,074,066$ \\
\hline 2016 & OCT & $248,972,000$ & $541,001,630$ & $27,080,998$ & $112,456,333$ & $191,430,000$ & $513,168,295$ \\
\hline 2016 & NOV & $191,430,000$ & $551,337,830$ & $32,710,926$ & $129,651,029$ & $106,101,000$ & $539,726,727$ \\
\hline 2016 & DEC & $106,101,000$ & $543,659,510$ & $31,989,982$ & $130,350,426$ & $68,821,000$ & $482,579,066$ \\
\hline 2017 & JAN & $68,821,000$ & $530,296,280$ & $26,244,627$ & $116,447,818$ & $95,365,000$ & $413,549,089$ \\
\hline 2017 & FEB & $95,365,000$ & $489,148,360$ & $23,791,658$ & $112,827,563$ & $125,167,000$ & $370,310,455$ \\
\hline 2017 & MAR & $125,167,000$ & $558,056,360$ & $28,235,994$ & $130,273,770$ & $90,193,000$ & $490,992,584$ \\
\hline 2017 & APR & $90,193,000$ & $489,296,020$ & $26,814,154$ & $113,208,987$ & $112,815,000$ & $380,279,187$ \\
\hline 2017 & MAY & $112,815,000$ & $515,800,990$ & $28,847,664$ & $129,538,314$ & $143,641,000$ & $384,284,340$ \\
\hline 2017 & JUN & $143,641,000$ & $505,292,520$ & $31,626,688$ & $112,998,024$ & $178,311,000$ & $389,251,184$ \\
\hline 2017 & JUL & $178,311,000$ & $458,951,890$ & $30,818,171$ & $96,296,791$ & $194,968,000$ & $376,816,270$ \\
\hline
\end{tabular}


Table A3. Ham Supply \& Utilization (continued)

\begin{tabular}{|c|c|c|c|c|c|c|c|}
\hline Year & Mo. & Beg. Stocks & Production & Imports & Exports & Ending Stocks & Disappearance \\
\hline 2017 & AUG & $194,968,000$ & $544,004,050$ & $35,952,620$ & $103,378,783$ & $203,887,000$ & $467,658,888$ \\
\hline 2017 & SEP & $203,887,000$ & $532,781,890$ & $31,897,854$ & $105,312,914$ & $232,034,000$ & $431,219,829$ \\
\hline 2017 & OCT & $232,034,000$ & $570,090,650$ & $33,074,707$ & $122,538,072$ & $195,327,000$ & $517,334,285$ \\
\hline 2017 & NOV & $195,327,000$ & $552,445,280$ & $36,187,534$ & $132,528,876$ & $98,224,000$ & $553,206,938$ \\
\hline 2017 & DEC & $98,224,000$ & $550,033,500$ & $32,180,855$ & $128,897,431$ & $81,082,000$ & $470,458,924$ \\
\hline 2018 & JAN & $81,082,000$ & $563,593,610$ & $31,254,108$ & $121,653,330$ & $118,407,000$ & $435,869,388$ \\
\hline 2018 & FEB & $118,407,000$ & $506,498,410$ & $28,242,724$ & $120,263,362$ & $122,743,000$ & $410,141,772$ \\
\hline 2018 & MAR & $122,743,000$ & $565,242,480$ & $30,512,371$ & $128,774,894$ & $96,339,000$ & $493,383,957$ \\
\hline 2018 & APR & $96,339,000$ & $527,121,590$ & $29,377,248$ & $135,935,493$ & $112,145,000$ & $404,757,345$ \\
\hline 2018 & MAY & $112,145,000$ & $535,119,840$ & $28,584,674$ & $127,559,652$ & $139,295,000$ & $408,994,863$ \\
\hline 2018 & JUN & $139,295,000$ & $494,316,460$ & $25,581,818$ & $110,404,243$ & $148,657,000$ & $400,132,034$ \\
\hline 2018 & JUL & $148,657,000$ & $488,631,550$ & $26,875,142$ & $104,717,524$ & $167,563,000$ & 3,168 \\
\hline 2018 & AUG & $167,563,000$ & $570,041,430$ & $25,397,067$ & $108,506,424$ & $204,763,000$ & 32,073 \\
\hline 2018 & SEP & $204,763,000$ & $495,374,690$ & $23,414,551$ & $108,268,070$ & $214,628,000$ & $400,656,171$ \\
\hline 2018 & OCT & $214,628,000$ & $603,068,050$ & $26,352,135$ & $125,470,886$ & $176,109,000$ & $542,468,299$ \\
\hline 2018 & NOV & $176,109,000$ & $577,842,800$ & $24,683,589$ & $124,775,996$ & $96,375,000$ & $557,484,394$ \\
\hline 2018 & DEC & $96,375,000$ & $549,319,810$ & $23,072,559$ & $124,267,839$ & $73,118,000$ & $471,381,530$ \\
\hline 2019 & JAN & $73,118,000$ & $584,142,960$ & $24,334,544$ & $117,151,142$ & $112,660,000$ & $451,784,362$ \\
\hline 2019 & FEB & $112,660,000$ & $533,421,750$ & $22,951,070$ & $110,251,235$ & $127,740,000$ & $431,041,585$ \\
\hline 2019 & MAR & $127,740,000$ & $565,340,920$ & $25,514,382$ & $126,129,060$ & $103,486,000$ & $488,980,242$ \\
\hline 2019 & APR & $103,486,000$ & $558,351,680$ & $21,981,658$ & $128,649,493$ & $121,331,000$ & $433,838,845$ \\
\hline 2019 & MAY & $121,331,000$ & $545,997,460$ & $21,899,616$ & $122,254,465$ & $150,109,000$ & $416,864,612$ \\
\hline 2019 & JUN & $150,109,000$ & $523,602,360$ & $22,149,488$ & $124,503,674$ & $168,599,000$ & $402,758,174$ \\
\hline 2019 & JUL & $168,599,000$ & $544,053,270$ & $25,321,799$ & $136,294,512$ & $182,555,000$ & $419,124,557$ \\
\hline 2019 & AUG & & $555,718,410$ & & & & \\
\hline 2019 & SEP & $202,454,000$ & $550,574,920$ & $24,963,864$ & $115,525,290$ & $201,258,000$ & $461,209,495$ \\
\hline 2019 & OCT & $201,258,000$ & $641,385,820$ & $26,660,864$ & $125,845,664$ & $173,760,000$ & $569,699,020$ \\
\hline 2019 & NOV & $173,760,000$ & $597,727,680$ & $24,688,160$ & $150,651,482$ & $110,635,000$ & $534,889,358$ \\
\hline 2019 & DEC & $110,635,000$ & $601,222,300$ & $21,544,191$ & $164,625,953$ & $84,981,000$ & $483,794,538$ \\
\hline 2020 & JAN & $84,981,000$ & $628,367,130$ & $22,362,085$ & $162,947,442$ & $114,618,000$ & $458,144,772$ \\
\hline 2020 & FEB & $114,618,000$ & $567,555,820$ & $20,305,753$ & $158,468,180$ & $114,534,000$ & $429,477,393$ \\
\hline 2020 & MAR & $114,534,000$ & $631,615,650$ & $21,666,126$ & $166,207,767$ & $88,308,000$ & $513,300,009$ \\
\hline 2020 & APR & $88,308,000$ & $499,779,880$ & $18,038,899$ & $147,970,281$ & $113,328,000$ & $344,828,498$ \\
\hline 2020 & MAY & $113,328,000$ & $462,569,560$ & $28,074,735$ & $142,414,961$ & $107,550,000$ & $354,007,334$ \\
\hline 2020 & JUN & $107,550,000$ & $590,738,440$ & $24,188,712$ & $132,270,135$ & $122,993,000$ & $467,214,018$ \\
\hline 2020 & JUL & $122,993,000$ & $583,675,370$ & $21,866,263$ & $142,761,935$ & $136,621,000$ & $449,151,698$ \\
\hline 2020 & AUG & $136,621,000$ & $576,169,320$ & $22,902,604$ & $132,707,763$ & $148,055,000$ & $454,930,161$ \\
\hline
\end{tabular}


Table A4. Loin Supply \& Utilization

\begin{tabular}{|c|c|c|c|c|c|c|c|}
\hline Year & Mo. & Beg. Stocks & Production & Imports & Exports & Ending Stocks & Disappearar \\
\hline 2010 & JAN & $35,884,000$ & $454,777,610$ & $7,927,873$ & $36,868,607$ & $34,440,000$ & $427,280,877$ \\
\hline 2010 & FEB & $, 440,000$ & 41,659, & 86 & $6,966,550$ & $7,017,000$ & 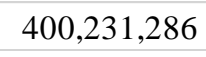 \\
\hline 2010 & MAR & $37,017,000$ & $512,677,130$ & $, 384,261$ & $47,847,592$ & $40,704,000$ & $470,526,800$ \\
\hline 2010 & APR & $40,704,000$ & 464,67 & 02 & 8,567 & $5,261,000$ & 30 \\
\hline 2010 & MAY & 00 & 41 & & 94 & 00 &, 538 \\
\hline 2010 & JUN & 27,98 & 460, & 45 & 47,9 & 87,000 &, 052 \\
\hline 2010 & JUL & 00 & 427 & & 93 & & 915 \\
\hline 2010 & AUG & $17,460,000$ & 4,890 & & & &, 395 \\
\hline 2010 & SEP & & & & & & 633 \\
\hline 2010 & OCT & 00 & 50 & & & & \\
\hline 2010 & NOV & 00 & 0 & & & & \\
\hline 2010 & DEC & & & & & & \\
\hline 2011 & JAN & 00 & 60 & 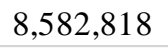 & 50 & 00 & 32 \\
\hline 2011 & FEB & & & & & & \\
\hline 2011 & MAR & 00 & 0 & & & & \\
\hline 2011 & APR & & & & & & \\
\hline 2011 & MAY & & & & & & \\
\hline 2011 & JUN & & & & & & \\
\hline 2011 & JUL & & & & & & \\
\hline 2011 & AUG & & & & & & \\
\hline 2011 & SEP & & & & & & \\
\hline 2011 & OCT & & & & & & \\
\hline 2011 & NOV & & & & & & \\
\hline 2011 & DEC & & & & & & \\
\hline 2012 & JAN & & & & & & \\
\hline 2012 & FEB & & & & & & \\
\hline 2012 & MAR & & & & & & \\
\hline 2012 & APR & & & & & & \\
\hline 2012 & MAY & & & & & & \\
\hline 2012 & JUN & & & & & & \\
\hline 2012 & JUL & & & & & & \\
\hline 2012 & AUG & & & & & & \\
\hline 2012 & SEP & & & & & & \\
\hline 2012 & OCT & & & & & & \\
\hline 2012 & NOV & & & & & & \\
\hline 2012 & DEC & & & & & 0 & \\
\hline 2013 & JAN & & & & & & \\
\hline 2013 & FEB & & & & & & \\
\hline 2013 & MAR & & & & & & 302417 \\
\hline 2013 & APR & & & & & & 15 \\
\hline 2013 & MAY & & & & & & \\
\hline 2013 & JUN & $38,630,000$ & $421,254,190$ & & $52,156,935$ & $28,845,000$ & $386,534,0$ \\
\hline & & & & & & & \\
\hline 2015 & AUU & $25,688,000$ & $487,119,920$ & $8,674,941$ & $54,554,504$ & $24,938,000$ & $441,990,357$ \\
\hline
\end{tabular}


Table A4. Loin Supply \& Utilization (continued)

\begin{tabular}{|c|c|c|c|c|c|c|c|}
\hline Year & Mo. & Beg. Stocks & Production & Imports & Exports & Ending Stocks & Disappearance \\
\hline 2013 & SEP & $24,938,000$ & $463,120,770$ & $9,314,032$ & $51,617,201$ & $23,662,000$ & $422,093,600$ \\
\hline 2013 & OCT & $23,662,000$ & $545,069,700$ & $9,635,353$ & $57,115,555$ & $28,448,000$ & $492,803,499$ \\
\hline 2013 & NOV & $28,448,000$ & $512,626,870$ & $9,703,636$ & $58,123,084$ & $40,298,000$ & $452,357,422$ \\
\hline 2013 & DEC & $40,298,000$ & $519,035,020$ & $9,296,178$ & $57,297,146$ & $44,700,000$ & $466,632,052$ \\
\hline 2014 & JAN & $44,700,000$ & $524,136,410$ & $9,327,027$ & $60,477,456$ & $42,796,000$ & $474,889,981$ \\
\hline 2014 & FEB & $42,796,000$ & $463,447,460$ & $8,708,008$ & $57,803,430$ & $45,373,000$ & $411,775,038$ \\
\hline 2014 & MAR & $45,373,000$ & $466,010,720$ & $10,477,978$ & $66,460,606$ & $41,470,000$ & $413,931,092$ \\
\hline 2014 & APR & $41,470,000$ & $480,234,300$ & $10,554,511$ & $62,062,101$ & $45,950,000$ & $424,246,710$ \\
\hline 2014 & MAY & $45,950,000$ & $467,191,830$ & $11,808,718$ & $58,694,440$ & $39,462,000$ & $426,794,108$ \\
\hline 2014 & JUN & $39,462,000$ & $435,754,200$ & $10,601,176$ & $56,196,633$ & $27,591,000$ & $402,029,743$ \\
\hline 2014 & JUL & $27,591,000$ & $452,289,740$ & $9,899,651$ & $52,295,607$ & $24,275,000$ & $413,209,785$ \\
\hline 2014 & AUG & $24,275,000$ & $440,327,860$ & $11,498,961$ & $46,736,059$ & $20,913,000$ & $408,452,763$ \\
\hline 2014 & SEP & $20,913,000$ & $470,408,470$ & $11,986,166$ & $44,685,280$ & $20,267,000$ & $438,355,356$ \\
\hline 2014 & OCT & $20,267,000$ & $534,364,320$ & $12,974,347$ & $52,192,600$ & $23,525,000$ & $491,888,067$ \\
\hline 2014 & NOV & $23,525,000$ & $475,007,260$ & $10,871,086$ & $49,496,976$ & $33,369,000$ & $426,537,370$ \\
\hline 2014 & DEC & $33,369,000$ & $531,323,590$ & $13,120,065$ & $49,755,545$ & $37,799,000$ & $490,258,110$ \\
\hline 2015 & JAN & $37,799,000$ & $528,860,850$ & $11,574,563$ & $46,688,709$ & $39,775,000$ & $491,770,704$ \\
\hline 2015 & FEB & $39,775,000$ & $488,828,760$ & $11,240,807$ & $52,550,632$ & $45,884,000$ & $441,409,935$ \\
\hline 2015 & MAR & $45,884,000$ & $530,695,340$ & $14,784,890$ & $55,171,105$ & $42,498,000$ & $493,695,125$ \\
\hline 2015 & APR & $42,498,000$ & $519,411,970$ & $13,016,366$ & $63,761,106$ & $44,634,000$ & $466,531,231$ \\
\hline 2015 & MAY & $44,634,000$ & $467,895,470$ & $11,260,648$ & $56,801,882$ & $39,360,000$ & $427,628,236$ \\
\hline 2015 & JUN & $39,360,000$ & $501,569,670$ & $12,974,421$ & $50,445,581$ & $37,408,000$ & $466,050,510$ \\
\hline 2015 & JUL & $37,408,000$ & $495,789,770$ & $11,638,442$ & $51,157,547$ & $33,968,000$ & $459,710,665$ \\
\hline 2015 & AUG & $33,968,000$ & $489,808,830$ & $12,579,693$ & $48,402,887$ & $31,399,000$ & $456,554,635$ \\
\hline 2015 & SEP & $31,399,000$ & $511,621,670$ & $12,443,218$ & $53,752,878$ & $30,012,000$ & $471,699,010$ \\
\hline 2015 & OCT & $30,012,000$ & $545,119,960$ & $13,793,781$ & $54,199,130$ & $28,905,000$ & $505,821,611$ \\
\hline 2015 & NOV & $28,905,000$ & $522,905,040$ & $13,494,600$ & $53,780,789$ & $44,033,000$ & $467,490,851$ \\
\hline 2015 & DEC & $44,033,000$ & $554,669,360$ & $14,246,242$ & $52,491,209$ & $46,221,000$ & $514,236,393$ \\
\hline 2016 & JAN & $46,221,000$ & $523,759,460$ & $13,578,185$ & $49,993,015$ & $46,702,000$ & $486,863,630$ \\
\hline 2016 & FEB & $46,702,000$ & $502,826,170$ & $13,532,748$ & $50,738,818$ & $42,735,000$ & $469,587,100$ \\
\hline 2016 & MAR & $42,735,000$ & $539,088,760$ & $15,320,620$ & $59,590,877$ & $47,917,000$ & $489,636,503$ \\
\hline 2016 & APR & $47,917,000$ & $502,650,260$ & $12,351,980$ & $54,580,754$ & $43,536,000$ & $464,802,486$ \\
\hline 2016 & MAY & $43,536,000$ & $489,783,700$ & $13,015,150$ & $55,743,735$ & $39,115,000$ & $451,476,115$ \\
\hline 2016 & JUN & $39,115,000$ & $505,992,550$ & $12,928,090$ & $54,449,337$ & $37,898,000$ & $465,688,303$ \\
\hline 2016 & JUL & $37,898,000$ & $458,496,850$ & $13,251,627$ & $48,932,155$ & $33,659,000$ & $427,055,323$ \\
\hline 2016 & AUG & $33,659,000$ & $540,194,480$ & $12,885,462$ & $51,717,162$ & $31,277,000$ & $503,744,780$ \\
\hline 2016 & SEP & $31,277,000$ & $534,339,190$ & $11,848,892$ & $51,557,225$ & $31,928,000$ & $493,979,857$ \\
\hline 2016 & OCT & $31,928,000$ & $552,432,790$ & $12,926,069$ & $57,611,926$ & $36,219,000$ & $503,455,933$ \\
\hline 2016 & NOV & $36,219,000$ & $562,987,390$ & $13,226,094$ & $64,600,557$ & $40,813,000$ & $507,018,927$ \\
\hline 2016 & DEC & $40,813,000$ & $555,146,830$ & $12,274,790$ & $59,430,939$ & $38,307,000$ & $510,496,681$ \\
\hline 2017 & JAN & $38,307,000$ & $541,501,240$ & $12,944,663$ & $56,033,982$ & $39,705,000$ & $497,013,921$ \\
\hline 2017 & FEB & $39,705,000$ & $499,483,880$ & $12,674,543$ & $55,820,658$ & $38,155,000$ & $457,887,765$ \\
\hline 2017 & MAR & $38,155,000$ & $569,847,880$ & $15,748,436$ & $65,828,277$ & $36,361,000$ & $521,562,039$ \\
\hline 2017 & APR & $36,361,000$ & $499,634,660$ & $14,422,654$ & $58,563,632$ & $42,872,000$ & $448,982,682$ \\
\hline 2017 & MAY & $42,872,000$ & $526,699,670$ & $14,537,667$ & $63,686,896$ & $40,357,000$ & $480,065,441$ \\
\hline 2017 & JUN & $40,357,000$ & $515,969,160$ & $15,168,152$ & $55,683,205$ & $39,897,000$ & $475,914,108$ \\
\hline 2017 & JUL & $39,897,000$ & $468,649,370$ & $14,340,425$ & $49,218,580$ & $33,878,000$ & $439,790,215$ \\
\hline
\end{tabular}


Table A4. Loin Supply \& Utilization (continued)

\begin{tabular}{|c|c|c|c|c|c|c|c|}
\hline Year & Mo. & Beg. Stocks & Production & Imports & Exports & Ending Stocks & Disappearance \\
\hline 2017 & AUG & $33,878,000$ & $555,498,650$ & $14,738,964$ & $52,658,512$ & $32,641,000$ & $518,816,102$ \\
\hline 2017 & SEP & $32,641,000$ & $544,039,370$ & $13,700,488$ & $52,549,746$ & $34,291,000$ & $503,540,112$ \\
\hline 2017 & OCT & $34,291,000$ & $582,136,450$ & $15,020,232$ & $63,393,271$ & $36,927,000$ & $531,127,411$ \\
\hline 2017 & $\mathrm{NOV}$ & $36,927,000$ & $564,118,240$ & $14,109,211$ & $67,818,082$ & $36,440,000$ & $510,896,369$ \\
\hline 2017 & DEC & $36,440,000$ & $561,655,500$ & $13,858,083$ & $64,282,564$ & $35,129,000$ & $512,542,019$ \\
\hline 2018 & JAN & $35,129,000$ & $575,502,130$ & $14,421,631$ & $60,847,506$ & $40,773,000$ & $523,432,255$ \\
\hline 2018 & FEB & $40,773,000$ & $517,200,530$ & $14,188,702$ & $62,351,960$ & $38,740,000$ & $471,070,272$ \\
\hline 2018 & MAR & $38,740,000$ & $577,185,840$ & $15,489,025$ & $70,891,952$ & $39,553,000$ & $520,969,913$ \\
\hline 2018 & APR & $39,553,000$ & $538,259,470$ & $16,319,052$ & $68,841,893$ & $39,830,000$ & $485,459,628$ \\
\hline 2018 & MAY & $39,830,000$ & $546,426,720$ & $15,409,979$ & $65,630,127$ & $36,519,000$ & $499,517,572$ \\
\hline 2018 & JUN & $36,519,000$ & $504,761,180$ & $13,911,098$ & $59,731,819$ & $31,949,000$ & $463,510,459$ \\
\hline 2018 & JUL & $31,949,000$ & $498,956,150$ & $14,156,914$ & $55,413,172$ & $26,614,000$ & $463,034,892$ \\
\hline 2018 & AUG & $26,614,000$ & $582,086,190$ & $13,788,471$ & $56,284,245$ & $30,575,000$ & $535,629,416$ \\
\hline 2018 & SEP & $30,575,000$ & $505,841,770$ & $12,538,624$ & $54,539,884$ & $33,763,000$ & $460,652,511$ \\
\hline 2018 & OCT & $33,763,000$ & $615,810,650$ & $13,821,252$ & $63,796,438$ & $34,216,000$ & $565,382,464$ \\
\hline 2018 & $\mathrm{NOV}$ & $34,216,000$ & $590,052,400$ & $13,531,286$ & $67,164,487$ & $33,923,000$ & $536,712,199$ \\
\hline 2018 & DEC & $33,923,000$ & $560,926,730$ & $13,622,275$ & $71,046,850$ & $34,092,000$ & $503,333,155$ \\
\hline 2019 & JAN & $34,092,000$ & $596,485,680$ & $14,471,962$ & $61,260,641$ & $34,945,000$ & $548,844,001$ \\
\hline 2019 & FEB & $34,945,000$ & $544,692,750$ & $13,835,796$ & $58,379,881$ & $38,648,000$ & $496,445,665$ \\
\hline 2019 & MAR & $38,648,000$ & $577,286,360$ & $15,832,929$ & $66,323,153$ & $41,627,000$ & $523,817,135$ \\
\hline 2019 & APR & $41,627,000$ & $570,149,440$ & $13,838,337$ & $67,860,836$ & $43,125,000$ & $514,628,941$ \\
\hline 2019 & MAY & $43,125,000$ & $557,534,180$ & $12,755,007$ & $68,470,847$ & $45,790,000$ & $499,153,340$ \\
\hline 2019 & JUN & $45,790,000$ & $534,665,880$ & $11,696,409$ & $64,578,848$ & $46,678,000$ & $480,895,441$ \\
\hline 2019 & JUL & $46,678,000$ & $555,548,910$ & $12,375,345$ & $75,451,614$ & $46,329,000$ & $492,821,641$ \\
\hline 2019 & AUG & $46,329,000$ & $567,460,530$ & & & & $510,630,726$ \\
\hline 2019 & SEP & $42,371,000$ & $562,208,360$ & $10,888,435$ & $64,434,472$ & $39,695,000$ & $511,338,323$ \\
\hline 2019 & OCT & $39,695,000$ & $654,938,060$ & $11,982,293$ & $74,818,730$ & $41,986,000$ & $589,810,623$ \\
\hline 2019 & NOV & $41,986,000$ & $610,357,440$ & $10,859,720$ & $89,666,400$ & $48,719,000$ & $524,817,760$ \\
\hline 2019 & DEC & $48,719,000$ & $613,925,900$ & $10,273,883$ & $99,563,369$ & $49,651,000$ & $523,704,413$ \\
\hline 2020 & JAN & $49,651,000$ & $641,644,290$ & $10,355,388$ & $95,926,118$ & $50,109,000$ & $555,615,560$ \\
\hline 2020 & FEB & $50,109,000$ & $579,548,060$ & $9,497,928$ & $96,797,856$ & $48,981,000$ & $493,376,132$ \\
\hline 2020 & MAR & $48,981,000$ & $644,961,450$ & $10,288,492$ & $103,373,960$ & $46,326,000$ & $554,530,982$ \\
\hline 2020 & APR & $46,326,000$ & $510,340,040$ & $8,901,923$ & $93,940,411$ & $40,517,000$ & $431,110,552$ \\
\hline 2020 & MAY & $40,517,000$ & $472,343,480$ & $12,718,449$ & $88,051,241$ & $27,502,000$ & $410,025,688$ \\
\hline 2020 & JUN & $27,502,000$ & $603,220,520$ & $12,834,263$ & $65,039,388$ & $32,187,000$ & $546,330,395$ \\
\hline 2020 & JUL & $32,187,000$ & $596,008,210$ & $11,527,705$ & $68,530,214$ & $37,189,000$ & $534,003,701$ \\
\hline 2020 & AUG & $37,189,000$ & $588,343,560$ & $13,029,264$ & $67,301,608$ & $39,714,000$ & $531,546,216$ \\
\hline
\end{tabular}


Table A5. Picnic Supply \& Utilization

\begin{tabular}{|c|c|c|c|c|c|c|c|}
\hline Year & Mo. & Beg. Stocks & Production & Imports & Exports & Ending Stocks & Disappearance \\
\hline 2010 & JAN & $8,889,000$ & $203,229,310$ & $5,481,181$ & $36,087,350$ & $8,223,000$ & $173,289,142$ \\
\hline 2010 & FEB & $8,223,000$ & $197,367,250$ & $5,788,335$ & $38,303,256$ & $9,400,000$ & $163,675,329$ \\
\hline 2010 & MAR & $9,400,000$ & $229,103,230$ & $6,456,485$ & $40,108,776$ & $12,607,000$ & $192,243,939$ \\
\hline 2010 & APR & $12,607,000$ & $207,653,930$ & $6,323,382$ & $37,457,012$ & $8,304,000$ & $180,823,300$ \\
\hline 2010 & MAY & $8,304,000$ & $182,071,990$ & $6,477,620$ & $39,429,086$ & $5,470,000$ & $151,954,524$ \\
\hline 2010 & JUN & $5,470,000$ & $205,699,910$ & $6,908,468$ & $40,680,804$ & $7,339,000$ & $170,058,574$ \\
\hline 2010 & JUL & $7,339,000$ & $191,157,060$ & $7,149,304$ & $36,114,351$ & $6,623,000$ & $162,908,013$ \\
\hline 2010 & AUG & $6,623,000$ & $203,858,190$ & $7,513,299$ & $34,170,649$ & $6,434,000$ & $177,389,840$ \\
\hline 2010 & SEP & $6,434,000$ & $211,517,050$ & $7,239,121$ & $34,116,298$ & $6,592,000$ & $184,481,873$ \\
\hline 2010 & OCT & $6,592,000$ & $224,903,210$ & $7,550,636$ & $36,862,476$ & $6,108,000$ & $196,075,370$ \\
\hline 2010 & NOV & $6,108,000$ & $232,236,400$ & $6,997,506$ & $44,270,960$ & $5,053,000$ & $196,017,946$ \\
\hline 2010 & DEC & $5,053,000$ & $230,821,420$ & $6,609,314$ & $44,352,917$ & $6,845,000$ & $191,285,816$ \\
\hline 2011 & JAN & $6,845,000$ & $212,943,260$ & $6,223,363$ & $40,405,392$ & $9,148,000$ & $176,458,230$ \\
\hline 2011 & FEB & $9,148,000$ & $198,557,630$ & $5,971,378$ & $40,938,266$ & $11,172,000$ & $161,566,742$ \\
\hline 2011 & MAR & $11,172,000$ & $230,709,120$ & $7,142,525$ & $50,862,110$ & $11,254,000$ & $186,907,535$ \\
\hline 2011 & APR & $11,254,000$ & $201,095,610$ & $6,522,156$ & $43,887,538$ & $9,458,000$ & $165,526,227$ \\
\hline 2011 & MAY & $9,458,000$ & $197,614,310$ & $6,592,976$ & $43,913,555$ & $11,482,000$ & $158,269,730$ \\
\hline 2011. & JUN & $11,482,000$ & $204,386,000$ & $5,858,048$ & $40,452,023$ & $12,403,000$ & $168,871,025$ \\
\hline 2011 & JUL & $12,403,000$ & $183,846,330$ & $5,373,371$ & $41,235,728$ & $9,707,000$ & $150,679,973$ \\
\hline 2011 & AUG & $9,707,000$ & $212,482,830$ & $5,841,038$ & $45,342,939$ & $7,239,000$ & $175,448,929$ \\
\hline 2011 & SEP & $7,239,000$ & $219,479,120$ & $5,844,342$ & $45,051,639$ & $9,293,000$ & $178,217,824$ \\
\hline 2011 & OCT & $9,293,000$ & $228,328,360$ & $6,108,942$ & $49,558,865$ & $8,615,000$ & $185,556,437$ \\
\hline 2011 & NOV & $8,615,000$ & $234,336,410$ & $6,395,180$ & $52,179,970$ & $10,499,000$ & $186,667,619$ \\
\hline 2011 & DEC & $10,499,000$ & $231,966,880$ & $5,766,256$ & $53,267,542$ & $9,337,000$ & $185,627,594$ \\
\hline 2012 & JAN & & & & & $10,898,000$ & $175,312,746$ \\
\hline 2012 & FEB & $10,898,000$ & $211,460,900$ & $5,778,049$ & $46,817,556$ & $12,068,000$ & $169,251,393$ \\
\hline 2012 & MAR & $12,068,000$ & $223,218,710$ & $6,332,605$ & $49,607,252$ & $9,311,000$ & $182,701,063$ \\
\hline 2012 & APR & $9,311,000$ & $206,845,370$ & $5,634,371$ & $46,293,137$ & $11,619,000$ & $163,878,604$ \\
\hline 2012 & MAY & $11,619,000$ & $216,379,640$ & $5,720,021$ & $46,904,325$ & $15,297,000$ & $171,517,335$ \\
\hline 2012 & JUN & $15,297,000$ & $196,581,150$ & $5,881,205$ & $43,386,930$ & $13,784,000$ & $160,588,425$ \\
\hline 2012 & JUL & $13,784,000$ & $193,369,370$ & $5,897,822$ & $43,598,353$ & $9,785,000$ & $159,667,839$ \\
\hline 2012 & AUG & & $224,386,630$ & $6,044,530$ & & $11,396,000$ & $183,038,975$ \\
\hline 2012 & SEP & $11,396,000$ & $214,627,760$ & $5,590,659$ & $47,482,355$ & $10,705,000$ & $173,427,065$ \\
\hline 2012 & OCT & $10,705,000$ & $248,261,610$ & $5,713,223$ & $53,988,994$ & $8,086,000$ & $202,604,839$ \\
\hline 2012 & NOV & $8,086,000$ & $233,494,160$ & $6,080,507$ & $49,806,200$ & $8,512,000$ & $189,342,467$ \\
\hline 2012 & DEC & $8,512,000$ & $219,456,660$ & $5,514,060$ & $46,092,791$ & $7,839,000$ & $179,550,930$ \\
\hline 2013 & JAN & $7,839,000$ & $231,888,270$ & $5,918,011$ & $44,704,721$ & $12,267,000$ & $188,673,560$ \\
\hline 2013 & FEB & $12,267,000$ & $199,714,320$ & $5,538,595$ & $40,755,035$ & $16,814,000$ & $159,950,880$ \\
\hline 2013 & MAR & $16,814,000$ & $216,963,600$ & $5,842,563$ & $40,157,212$ & $16,544,000$ & $182,918,951$ \\
\hline 2013 & APR & $16,544,000$ & $217,951,840$ & $5,902,470$ & $42,504,256$ & $21,152,000$ & $176,742,054$ \\
\hline 2013 & MAY & $21,152,000$ & $213,246,470$ & $6,313,207$ & $45,746,300$ & $16,265,000$ & $178,700,378$ \\
\hline 2013 & JUN & $16,265,000$ & $188,248,490$ & $5,849,303$ & $41,936,609$ & $13,669,000$ & $154,757,184$ \\
\hline 2013. & JUL & $13,669,000$ & $206,665,690$ & $6,561,168$ & $43,593,130$ & $12,719,000$ & $170,583,727$ \\
\hline 2013 & AUG & $12,719,000$ & $217,682,320$ & $6,307,932$ & $42,201,939$ & $13,808,000$ & $180,699,313$ \\
\hline
\end{tabular}


Table A5. Picnic Supply \& Utilization (continued)

\begin{tabular}{|c|c|c|c|c|c|c|c|}
\hline Year & Mo. & Beg. Stocks & Production & Imports & Exports & Ending Stocks & Disappearance \\
\hline 2013 & SEP & $13,808,000$ & $206,957,670$ & $6,629,471$ & $41,376,405$ & $13,115,000$ & $172,903,736$ \\
\hline 2013 & OCT & $13,115,000$ & $243,578,700$ & $6,845,071$ & $45,765,246$ & $11,192,000$ & $206,581,525$ \\
\hline 2013 & NOV & $11,192,000$ & $229,080,770$ & $6,716,768$ & $48,856,374$ & $8,810,000$ & $189,323,164$ \\
\hline 2013 & DEC & $8,810,000$ & $231,944,420$ & $6,304,807$ & $49,715,272$ & $7,889,000$ & $189,454,955$ \\
\hline 2014 & JAN & $7,889,000$ & $234,224,110$ & $6,004,914$ & $49,029,740$ & $9,920,000$ & $189,168,284$ \\
\hline 2014 & FEB & $9,920,000$ & $207,103,660$ & $5,568,976$ & $47,580,009$ & $11,716,000$ & $163,296,627$ \\
\hline 2014 & MAR & $11,716,000$ & $208,249,120$ & $6,298,568$ & $54,346,386$ & $9,080,000$ & $162,837,302$ \\
\hline 2014 & APR & $9,080,000$ & $214,605,300$ & $6,669,091$ & $49,461,952$ & $13,204,000$ & $167,688,439$ \\
\hline 2014 & MAY & $13,204,000$ & $208,776,930$ & $7,645,926$ & $47,959,684$ & $9,413,000$ & $172,254,173$ \\
\hline 2014 & JUN & $9,413,000$ & $194,728,200$ & $6,977,671$ & $47,627,407$ & $7,638,000$ & $155,853,464$ \\
\hline 2014 & JUL & $7,638,000$ & $202,117,540$ & $6,539,948$ & $45,449,940$ & $6,909,000$ & $163,936,547$ \\
\hline 2014 & AUG & $6,909,000$ & $196,772,060$ & $7,602,515$ & $41,376,718$ & $8,505,000$ & $161,401,856$ \\
\hline 2014 & SEP & $8,505,000$ & $210,214,370$ & $7,807,753$ & $40,868,880$ & $10,513,000$ & $175,145,244$ \\
\hline 2014 & OCT & $10,513,000$ & $238,794,720$ & $8,882,438$ & $45,258,401$ & $10,893,000$ & $202,038,756$ \\
\hline 2014 & NOV & $10,893,000$ & $212,269,460$ & $7,656,270$ & $42,631,588$ & $10,860,000$ & $177,327,142$ \\
\hline 2014 & DEC & $10,860,000$ & $237,435,890$ & $8,940,989$ & $45,583,747$ & $8,827,000$ & $202,826,132$ \\
\hline 2015 & JAN & $8,827,000$ & $236,335,350$ & $8,080,951$ & $40,184,212$ & $12,811,000$ & $200,248,089$ \\
\hline 2015 & FEB & $12,811,000$ & $218,445,960$ & $7,323,379$ & $43,084,123$ & $19,339,000$ & $176,157,215$ \\
\hline 2015 & MAR & $19,339,000$ & $237,155,140$ & $9,291,675$ & $51,243,327$ & $19,582,000$ & $194,960,488$ \\
\hline 2015 & APR & $19,582,000$ & $232,112,870$ & $7,849,109$ & $51,628,716$ & $16,239,000$ & $191,676,262$ \\
\hline 2015 & MAY & $16,239,000$ & $209,091,370$ & $7,036,268$ & $49,452,991$ & $10,867,000$ & $172,046,647$ \\
\hline 2015 & JUN & $10,867,000$ & $224,139,570$ & $8,559,871$ & $48,748,773$ & $8,757,000$ & $186,060,668$ \\
\hline 2015 & JUL & $8,757,000$ & $221,556,670$ & $7,712,335$ & $45,672,787$ & $9,680,000$ & $182,673,219$ \\
\hline 2015 & AUG & $9,680,000$ & $218,883,930$ & $7,945,974$ & $42,840,009$ & $11,767,000$ & $181,902,896$ \\
\hline 2015 & SEP & $11,767,000$ & $228,631,570$ & $7,973,150$ & $44,088,175$ & $10,490,000$ & $193,793,545$ \\
\hline 2015 & OCT & $10,490,000$ & $243,601,160$ & $8,659,912$ & $46,880,921$ & $8,816,000$ & $207,054,152$ \\
\hline 2015 & NOV & $8,816,000$ & $233,673,840$ & $8,761,629$ & $50,057,638$ & $10,972,000$ & $190,221,831$ \\
\hline 2015 & DEC & $10,972,000$ & $247,868,560$ & $9,031,939$ & $49,747,444$ & $10,634,000$ & $207,491,054$ \\
\hline 2016 & JAN & $10,634,000$ & $234,055,660$ & $8,118,753$ & $44,155,987$ & $10,705,000$ & $197,947,425$ \\
\hline 2016 & FEB & $10,705,000$ & $224,701,070$ & $8,674,911$ & $43,428,204$ & $11,142,000$ & $189,510,777$ \\
\hline 2016 & MAR & $11,142,000$ & $240,905,960$ & $9,191,268$ & $49,241,455$ & $10,420,000$ & $201,577,772$ \\
\hline 2016 & APR & $10,420,000$ & $224,622,460$ & $8,078,127$ & $48,830,208$ & $11,470,000$ & $182,820,379$ \\
\hline 2016 & MAY & $11,470,000$ & $218,872,700$ & $8,363,938$ & $53,835,705$ & $9,914,000$ & $174,956,933$ \\
\hline 2016 & JUN & $9,914,000$ & $226,116,050$ & $8,051,444$ & $48,982,444$ & $7,959,000$ & $187,140,049$ \\
\hline 2016 & JUL & $7,959,000$ & $204,891,350$ & $8,487,118$ & $47,681,680$ & $8,022,000$ & $165,633,787$ \\
\hline 2016 & AUG & $8,022,000$ & $241,400,080$ & $8,419,835$ & $46,920,735$ & $8,446,000$ & $202,475,180$ \\
\hline 2016 & SEP & $8,446,000$ & $238,783,490$ & $8,070,252$ & $46,817,766$ & $8,512,000$ & $199,969,976$ \\
\hline 2016 & OCT & $8,512,000$ & $246,869,090$ & & $50,070,958$ & $11,294,000$ & $202,731,842$ \\
\hline 2016 & NOV & $11,294,000$ & $251,585,690$ & $8,924,320$ & $56,921,339$ & $8,980,000$ & $205,902,671$ \\
\hline 2016 & DEC & $8,980,000$ & $248,081,930$ & $8,194,084$ & $57,195,722$ & $8,321,000$ & $199,739,291$ \\
\hline 2017 & JAN & $8,321,000$ & $241,984,040$ & $8,135,810$ & $52,030,690$ & $8,993,000$ & $197,417,159$ \\
\hline 2017 & FEB & $8,993,000$ & $223,207,480$ & $7,821,256$ & $50,187,975$ & $8,437,000$ & $181,396,761$ \\
\hline 2017 & MAR & $8,437,000$ & $254,651,480$ & $9,601,617$ & $57,693,109$ & $8,783,000$ & $206,213,988$ \\
\hline 2017 & APR & $8,783,000$ & $223,274,860$ & $9,046,884$ & $51,020,059$ & $7,210,000$ & $182,874,685$ \\
\hline 2017 & MAY & $7,210,000$ & $235,369,570$ & $8,815,122$ & $57,846,681$ & $7,741,000$ & $185,807,011$ \\
\hline 2017 & JUN & $7,741,000$ & $230,574,360$ & $9,052,419$ & $50,228,193$ & $7,698,000$ & $189,441,587$ \\
\hline 2017 & JUL & $7,698,000$ & $209,428,270$ & $8,609,186$ & $42,821,606$ & $6,648,000$ & $176,265,849$ \\
\hline
\end{tabular}


Table A5. Picnic Supply \& Utilization (continued)

\begin{tabular}{|c|c|c|c|c|c|c|c|}
\hline Year & Mo. & Beg. Stocks & Production & Imports & Exports & Ending Stocks & Disappearance \\
\hline 2017 & AUG & $6,648,000$ & $248,239,150$ & $9,120,985$ & $45,787,682$ & $8,176,000$ & $210,044,453$ \\
\hline 2017 & SEP & $8,176,000$ & $243,118,270$ & $8,335,613$ & $47,189,034$ & $8,745,000$ & $203,695,849$ \\
\hline 2017 & OCT & $8,745,000$ & $260,142,950$ & $9,769,410$ & $54,240,166$ & $8,055,000$ & $216,362,194$ \\
\hline 2017 & NOV & $8,055,000$ & $252,091,040$ & $9,732,767$ & $59,203,297$ & $6,866,000$ & $203,809,510$ \\
\hline 2017 & DEC & $6,866,000$ & $250,990,500$ & $9,445,847$ & $58,134,935$ & $5,982,000$ & $203,185,412$ \\
\hline 2018 & JAN & $5,982,000$ & $257,178,230$ & $9,884,964$ & $54,100,472$ & $7,074,000$ & $211,870,722$ \\
\hline 2018 & FEB & $7,074,000$ & $231,124,630$ & $9,055,112$ & $53,938,704$ & $8,644,000$ & $184,671,037$ \\
\hline 2018 & MAR & $8,644,000$ & $257,930,640$ & $9,993,413$ & $57,472,745$ & $11,314,000$ & $207,781,308$ \\
\hline 2018 & APR & $11,314,000$ & $240,535,370$ & $10,338,588$ & $60,744,329$ & $10,094,000$ & $191,349,629$ \\
\hline 2018 & MAY & $10,094,000$ & $244,185,120$ & $9,331,038$ & $56,893,710$ & $10,110,000$ & $196,606,448$ \\
\hline 2018 & JUN & $10,110,000$ & $225,565,780$ & $8,332,224$ & $49,019,680$ & $7,268,000$ & $187,720,324$ \\
\hline 2018 & JUL & $7,268,000$ & $222,971,650$ & $9,123,543$ & $46,070,971$ & $8,157,000$ & $185,135,222$ \\
\hline 2018 & AUG & $8,157,000$ & $260,120,490$ & $8,348,387$ & $48,279,556$ & $8,874,000$ & $219,472,321$ \\
\hline 2018 & SEP & $8,874,000$ & $226,048,670$ & $7,948,509$ & $47,640,035$ & $8,375,000$ & $186,856,145$ \\
\hline 2018 & OCT & $8,375,000$ & $275,191,150$ & $8,818,186$ & $55,330,814$ & $7,879,000$ & $229,174,521$ \\
\hline 2018 & $\mathrm{NOV}$ & $7,879,000$ & $263,680,400$ & $8,676,939$ & $55,100,022$ & $6,644,000$ & $218,492,317$ \\
\hline 2018 & DEC & $6,644,000$ & $250,664,830$ & $8,223,228$ & $55,426,142$ & $6,832,000$ & $203,273,916$ \\
\hline 2019 & JAN & $6,832,000$ & $266,555,280$ & $8,739,707$ & $52,273,849$ & $7,067,000$ & $222,786,138$ \\
\hline 2019 & FEB & $7,067,000$ & $243,410,250$ & $8,900,233$ & $49,133,360$ & $6,742,000$ & $203,502,123$ \\
\hline 2019 & MAR & $6,742,000$ & $257,975,560$ & $9,351,048$ & $55,982,579$ & $8,019,000$ & $210,067,030$ \\
\hline 2019 & APR & $8,019,000$ & $254,786,240$ & $8,495,020$ & $57,440,281$ & $9,926,000$ & $203,933,979$ \\
\hline 2019 & MAY & $9,926,000$ & $249,148,780$ & $7,600,505$ & $54,477,413$ & $7,561,000$ & $204,636,872$ \\
\hline 2019 & JUN & $7,561,000$ & $238,929,480$ & $7,432,661$ & $54,803,740$ & $7,920,000$ & $191,199,401$ \\
\hline 2019 & JUL & $7,920,000$ & $248,261,610$ & $7,663,910$ & $60,173,113$ & $7,940,000$ & $195,732,407$ \\
\hline 2019 & AUG & $7,940,000$ & $253,584,630$ & $8,092,359$ & $55,810,908$ & $10,063,000$ & $203,743,081$ \\
\hline 2019 & SEP & $10,063,000$ & $251,237,560$ & $7,326,901$ & $51,280,196$ & $8,582,000$ & $208,765,265$ \\
\hline 2019 & OCT & $8,582,000$ & $292,676,260$ & $8,502,693$ & $55,764,903$ & $9,923,000$ & $244,073,050$ \\
\hline 2019 & NOV & $9,923,000$ & $272,754,240$ & $7,204,245$ & $67,531,469$ & $7,506,000$ & $214,844,016$ \\
\hline 2019 & DEC & $7,506,000$ & $274,348,900$ & $6,781,766$ & $74,319,031$ & $7,991,000$ & $206,326,635$ \\
\hline 2020 & JAN & $7,991,000$ & $286,735,590$ & $7,051,205$ & $73,606,427$ & $10,559,000$ & $217,612,369$ \\
\hline 2020 & FEB & $10,559,000$ & $258,986,260$ & $6,450,779$ & $71,377,931$ & $12,164,000$ & $192,454,108$ \\
\hline 2020 & MAR & $12,164,000$ & $288,217,950$ & $7,126,649$ & $74,728,633$ & $10,807,000$ & $221,972,966$ \\
\hline 2020 & APR & $10,807,000$ & $228,058,840$ & $6,230,684$ & $66,437,042$ & $13,453,000$ & $165,206,482$ \\
\hline 2020 & MAY & $13,453,000$ & $211,079,080$ & $8,286,063$ & $64,279,326$ & $10,402,000$ & $158,136,816$ \\
\hline 2020 & JUN & $10,402,000$ & $269,564,920$ & $8,969,473$ & $59,758,258$ & $8,694,000$ & $220,484,135$ \\
\hline 2020 & JUL & $8,694,000$ & $266,341,910$ & $8,315,082$ & $64,334,910$ & $7,089,000$ & $211,927,082$ \\
\hline 2020 & AUG & $7,089,000$ & $262,916,760$ & $9,255,111$ & $60,006,068$ & $7,610,000$ & $211,644,802$ \\
\hline
\end{tabular}


Table A6. Rib Supply \& Utilization

\begin{tabular}{|c|c|c|c|c|c|c|c|}
\hline Year & Mo. & Beg. Stocks & Production & Imports & Exports & Ending Stocks & Disappearan \\
\hline 2010 & JAN & $96,000,000$ & $83,608,140$ & $2,295,317$ & $6,839,479$ & $93,298,000$ & $81,765,978$ \\
\hline 2010 & FEB & $, 298,000$ & $, 196,500$ & 269,564 & $8,712,744$ & $95,530,000$ & 1,321 \\
\hline 2010 & MAR & $, 530,000$ & $4,252,620$ & ,490,850 & $8,876,185$ & $102,190,000$ & $, 207,284$ \\
\hline 2010 & APR & $102,190,000$ & $5,428,420$ & 357,568 & $9,009,752$ & $81,134,000$ & 236 \\
\hline 2010 & MAY & 000 & 60 & 49 & 9,30 &, 000 & ,950 \\
\hline 2010 & JUN & $, 762,000$ & $84,624,540$ & 562 & $8,888,524$ & $42,662,000$ & $99,025,678$ \\
\hline 2010 & JUL & 00 & $, 641,640$ & 8 & 01 & 000 & 077 \\
\hline 2010 & AUG & $39,452,000$ & 60 & 61 & 7,0 & 000 & \\
\hline 2010 & SEP & 00 & & 8 & 0 & & \\
\hline 2010 & OCT & 00 & & 4 & $8,256,055$ & 023,000 & \\
\hline 2010 & NOV & 00 & & 24 & & & \\
\hline 2010 & DEC & & & 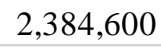 & & & \\
\hline 2011 & JAN & 81,62 & 87, & 2,20 & 8,95 & 000 & ,771 \\
\hline 2011 & FEB & & & & 10 & & \\
\hline 2011 & MAR & 0 & 0 & 45 & 12,7 & 00 & \\
\hline 2011 & APR & & & & & & \\
\hline 2011 & MAY & 0 & & & 10,2 & 00 & \\
\hline 2011 & JUN & & & & & & \\
\hline 2011 & JUL & & & & & & \\
\hline 2011 & AUG & & & & 1 & & \\
\hline 2011 & SEP & & & 8 & & & \\
\hline 2011 & OCT & & & & & & \\
\hline 2011 & NOV & & & & & & \\
\hline 2011 & DEC & & & & & & \\
\hline 2012 & JAN & & & & & & \\
\hline 2012 & FEB & & & & & & \\
\hline 2012 & MAR & & & & 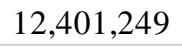 & 00 & \\
\hline 2012 & APR & 0 & 80 & 2,2 & 11,3 & 000 & \\
\hline 2012 & MAY & & & & & & \\
\hline 2012 & JUN & & & & & & \\
\hline 2012 & JUL & & & & & & \\
\hline 2012 & AUG & ,000 & & & 1 & 0,000 & 89. \\
\hline 2012 & SEP & & & & & & \\
\hline 2012 & OCT & & 40 & & 1 & ,000 & 78, \\
\hline 2012 & NOV & 79,45 & & & & 00 & 221 \\
\hline 2012 & DEC & 0 & & & 03 & 5,000 & $76,210,0$ \\
\hline 2013 & JAN & & & & & & $82,334,16$ \\
\hline 2013 & FEB & & & & & 9,000 & 1 \\
\hline 2013 & MAR & $119,439,000$ & & & 10,0 & 00 & $78,776,18$ \\
\hline 2013 & APR & & & & $6 a^{2}$ & 0 & $84,231,637$ \\
\hline 2013 & MAY & 120 & & & & & $109,200,231$ \\
\hline 2013 & JUN & $91,153,000$ & & $2,181,444$ & $9,675,610$ & $56,652,000$ & $104,451,894$ \\
\hline 201 & JUL & & & & & & \\
\hline 2013 & AUG & $57,631,000$ & $89,554,080$ & $2,663,484$ & $10,120,382$ & $48,298,000$ & $91,430,182$ \\
\hline
\end{tabular}


Table A6. Rib Supply \& Utilization (continued)

\begin{tabular}{|c|c|c|c|c|c|c|c|}
\hline Year & Mo. & Beg. Stocks & Production & Imports & Exports & Ending Stocks & Disappearance \\
\hline 2013 & SEP & $48,298,000$ & $85,141,980$ & $2,823,693$ & $9,575,484$ & $56,107,000$ & $70,581,189$ \\
\hline 2013 & OCT & $56,107,000$ & $100,207,800$ & $2,840,777$ & $10,595,481$ & $75,746,000$ & $72,814,096$ \\
\hline 2013 & NOV & $75,746,000$ & $94,243,380$ & $2,611,556$ & $10,782,387$ & $98,853,000$ & $62,965,549$ \\
\hline 2013 & DEC & $98,853,000$ & $95,421,480$ & $2,510,916$ & $10,629,168$ & $106,589,000$ & $79,567,228$ \\
\hline 2014 & JAN & $106,589,000$ & $96,359,340$ & $2,620,636$ & $11,219,146$ & $112,246,000$ & $82,103,830$ \\
\hline 2014 & FEB & $112,246,000$ & $85,202,040$ & $2,202,664$ & $10,723,089$ & $122,859,000$ & $66,068,615$ \\
\hline 2014 & MAR & $122,859,000$ & $85,673,280$ & $2,487,532$ & $12,329,077$ & $120,606,000$ & $78,084,735$ \\
\hline 2014 & APR & $120,606,000$ & $88,288,200$ & $2,498,925$ & $11,513,113$ & $115,957,000$ & $83,923,012$ \\
\hline 2014 & MAY & $115,957,000$ & $85,890,420$ & $3,007,742$ & $10,888,379$ & $89,596,000$ & $104,370,783$ \\
\hline 2014 & JUN & $89,596,000$ & $80,110,800$ & $2,768,415$ & $10,425,012$ & $59,943,000$ & $102,107,202$ \\
\hline 2014 & JUL & $59,943,000$ & $83,150,760$ & $2,601,358$ & $9,701,335$ & $55,140,000$ & $80,853,784$ \\
\hline 2014 & AUG & $55,140,000$ & $80,951,640$ & $2,942,611$ & $8,669,985$ & $49,621,000$ & $80,743,266$ \\
\hline 2014 & SEP & $49,621,000$ & $86,481,780$ & $3,104,677$ & $8,289,546$ & $53,957,000$ & $76,960,911$ \\
\hline 2014 & OCT & $53,957,000$ & $98,239,680$ & $3,258,479$ & $9,682,226$ & $69,374,000$ & $76,398,933$ \\
\hline 2014 & NOV & $69,374,000$ & $87,327,240$ & $2,736,580$ & $9,182,162$ & $76,897,000$ & $73,358,658$ \\
\hline 2014 & DEC & $76,897,000$ & $97,680,660$ & $3,126,985$ & $9,230,129$ & $87,020,000$ & $81,454,516$ \\
\hline 2015 & JAN & $87,020,000$ & $97,227,900$ & $2,943,331$ & $8,661,202$ & $94,863,000$ & $83,667,030$ \\
\hline 2015 & FEB & $94,863,000$ & $89,868,240$ & $2,757,890$ & $9,748,644$ & $106,781,000$ & $70,959,486$ \\
\hline 2015 & MAR & $106,781,000$ & $97,565,160$ & $3,507,535$ & $10,234,767$ & $115,372,000$ & $82,246,928$ \\
\hline 2015 & APR & $115,372,000$ & $95,490,780$ & $2,638,009$ & $11,828,294$ & $113,832,000$ & $87,840,495$ \\
\hline 2015 & MAY & $113,832,000$ & $86,019,780$ & $2,322,868$ & $10,537,292$ & $89,290,000$ & $102,347,356$ \\
\hline 2015 & JUN & $89,290,000$ & $92,210,580$ & $2,650,456$ & $9,358,137$ & $73,022,000$ & $101,770,899$ \\
\hline 2015 & JUL & $73,022,000$ & $91,147,980$ & $2,348,753$ & $9,490,214$ & $75,533,000$ & $81,495,520$ \\
\hline 2015 & AUG & $75,533,000$ & $90,048,420$ & $2,520,103$ & $8,979,198$ & $72,626,000$ & $86,496,325$ \\
\hline 2015 & SEP & $72,626,000$ & $94,058,580$ & $2,467,337$ & $9,971,672$ & $85,335,000$ & $73,845,244$ \\
\hline 2015 & OCT & $85,335,000$ & $100,217,040$ & $2,731,916$ & $10,054,456$ & $98,871,000$ & $79,358,499$ \\
\hline 2015 & NOV & $98,871,000$ & $96,132,960$ & $2,809,177$ & $9,976,850$ & $117,148,000$ & $70,688,287$ \\
\hline 2015 & DEC & $117,148,000$ & $101,972,640$ & $2,925,887$ & $9,737,621$ & $134,777,000$ & $77,531,906$ \\
\hline 2016 & JAN & $134,777,000$ & $96,290,040$ & $2,628,387$ & $9,274,182$ & $139,914,000$ & $84,507,245$ \\
\hline 2016 & FEB & $139,914,000$ & $92,441,580$ & $2,719,842$ & $9,412,536$ & $143,396,000$ & $82,266,887$ \\
\hline 2016 & MAR & $143,396,000$ & $99,108,240$ & $2,931,843$ & $11,054,677$ & $146,135,000$ & $88,246,406$ \\
\hline 2016 & APR & $146,135,000$ & $92,409,240$ & & $10,125,251$ & $138,117,000$ & $92,710,381$ \\
\hline 2016 & MAY & $138,117,000$ & $90,043,800$ & $2,535,245$ & $10,340,995$ & $109,997,000$ & $110,358,050$ \\
\hline 2016 & JUN & $109,997,000$ & $93,023,700$ & $2,546,130$ & $10,100,872$ & $85,635,000$ & $109,830,958$ \\
\hline 2016 & JUL & $85,635,000$ & $84,291,900$ & $2,720,672$ & $9,077,382$ & $90,139,000$ & $73,431,189$ \\
\hline 2016 & AUG & $90,139,000$ & $99,311,520$ & $2,515,981$ & $9,594,028$ & $75,957,000$ & $106,415,474$ \\
\hline 2016 & SEP & $75,957,000$ & $98,235,060$ & $2,486,545$ & $9,564,358$ & $83,729,000$ & $83,385,247$ \\
\hline 2016 & OCT & $83,729,000$ & $101,561,460$ & $2,492,585$ & $10,687,563$ & $98,916,000$ & $78,179,482$ \\
\hline 2016 & NOV & $98,916,000$ & $103,501,860$ & $2,534,841$ & $11,984,020$ & $109,413,000$ & $83,555,680$ \\
\hline 2016 & DEC & $109,413,000$ & $102,060,420$ & $2,372,877$ & $11,025,007$ & $115,590,000$ & $87,231,290$ \\
\hline 2017 & JAN & $115,590,000$ & $99,551,760$ & $2,462,538$ & $10,394,839$ & $128,029,000$ & $79,180,459$ \\
\hline 2017 & FEB & $128,029,000$ & $91,827,120$ & $2,419,294$ & $10,355,265$ & $139,525,000$ & $72,395,149$ \\
\hline 2017 & MAR & $139,525,000$ & $104,763,120$ & $3,012,188$ & $12,211,774$ & $140,639,000$ & $94,449,533$ \\
\hline 2017 & APR & $140,639,000$ & $91,854,840$ & $2,758,547$ & $10,864,113$ & $136,875,000$ & $87,513,274$ \\
\hline 2017 & MAY & $136,875,000$ & $96,830,580$ & $2,805,085$ & $11,814,528$ & $114,460,000$ & $110,236,137$ \\
\hline 2017 & JUN & $114,460,000$ & $94,857,840$ & $2,880,932$ & $10,329,766$ & $85,993,000$ & $115,876,005$ \\
\hline 2017 & JUL & $85,993,000$ & $86,158,380$ & $2,752,001$ & $9,130,517$ & $77,182,000$ & $88,590,864$ \\
\hline 2017 & AUG & $77,182,000$ & $102,125,100$ & $2,756,106$ & $9,768,657$ & $74,341,000$ & $97,953,549$ \\
\hline
\end{tabular}


Table A6. Rib Supply \& Utilization (continued)

\begin{tabular}{|c|c|c|c|c|c|c|c|}
\hline Year & Mo. & Beg. Stocks & Production & Imports & Exports & Ending Stocks & Disappearance \\
\hline 2017 & SEP & $74,341,000$ & $100,018,380$ & $2,569,899$ & $9,748,480$ & $88,032,000$ & $79,148,799$ \\
\hline 2017 & OCT & $88,032,000$ & $107,022,300$ & $2,821,887$ & $11,760,058$ & $94,859,000$ & $91,257,130$ \\
\hline 2017 & NOV & $94,859,000$ & $103,709,760$ & $2,623,566$ & $12,580,902$ & $100,218,000$ & $88,393,424$ \\
\hline 2017 & DEC & $100,218,000$ & $103,257,000$ & $2,577,421$ & $11,925,030$ & $104,264,000$ & $89,863,391$ \\
\hline 2018 & JAN & $104,264,000$ & $105,802,620$ & $2,685,932$ & $11,287,794$ & $114,366,000$ & $87,098,759$ \\
\hline 2018 & FEB & $114,366,000$ & $95,084,220$ & $2,638,533$ & $11,566,884$ & $131,600,000$ & $68,921,869$ \\
\hline 2018 & MAR & $131,600,000$ & $106,112,160$ & $2,957,836$ & $13,151,134$ & $143,957,000$ & $83,561,862$ \\
\hline 2018 & APR & $143,957,000$ & $98,955,780$ & $3,125,478$ & $12,770,829$ & $143,717,000$ & $89,550,429$ \\
\hline 2018 & MAY & $143,717,000$ & $100,457,280$ & $3,005,709$ & $12,175,016$ & $119,286,000$ & $115,718,973$ \\
\hline 2018 & JUN & $119,286,000$ & $92,797,320$ & $2,753,073$ & $11,080,823$ & $88,871,000$ & $114,884,570$ \\
\hline 2018 & JUL & $88,871,000$ & $91,730,100$ & $2,768,000$ & $10,279,673$ & $84,171,000$ & $88,918,427$ \\
\hline 2018 & AUG & $84,171,000$ & $107,013,060$ & $2,760,277$ & $10,441,265$ & $77,803,000$ & $105,700,072$ \\
\hline 2018 & SEP & $77,803,000$ & $92,995,980$ & $2,405,877$ & $10,117,669$ & $83,403,000$ & $79,684,187$ \\
\hline 2018 & OCT & $83,403,000$ & $113,213,100$ & $2,726,773$ & $11,834,849$ & $101,369,000$ & $86,139,024$ \\
\hline 2018 & $\mathrm{NOV}$ & $101,369,000$ & $108,477,600$ & $2,550,968$ & $12,459,654$ & $108,324,000$ & $91,613,914$ \\
\hline 2018 & DEC & $108,324,000$ & $103,123,020$ & $2,537,424$ & $13,179,870$ & $124,310,000$ & $76,494,574$ \\
\hline 2019 & JAN & $124,310,000$ & $109,660,320$ & $2,767,070$ & $11,364,434$ & $127,110,000$ & $98,262,956$ \\
\hline 2019 & FEB & $127,110,000$ & $100,138,500$ & $2,817,697$ & $10,830,026$ & $142,606,000$ & $76,630,171$ \\
\hline 2019 & MAR & $142,606,000$ & $106,130,640$ & $3,276,743$ & $12,303,579$ & $140,780,000$ & $98,929,804$ \\
\hline 2019 & APR & $140,780,000$ & $104,818,560$ & $2,809,821$ & $12,588,833$ & $146,859,000$ & $88,960,548$ \\
\hline 2019 & MAY & $146,859,000$ & $102,499,320$ & $2,632,872$ & $12,701,996$ & $127,769,000$ & $111,520,196$ \\
\hline 2019 & JUN & $127,769,000$ & $98,295,120$ & $2,384,614$ & $11,979,993$ & $101,647,000$ & $114,821,741$ \\
\hline 2019 & JUL & $101,647,000$ & $102,134,340$ & $2,489,486$ & $13,996,995$ & $84,867,000$ & $107,406,831$ \\
\hline 2019 & AUG & $84,867,000$ & $104,324,220$ & $2,543,996$ & $13,457,614$ & $79,353,000$ & $98,924,602$ \\
\hline 2019 & SEP & $79,353,000$ & $103,358,640$ & $2,196,330$ & $11,953,210$ & $85,287,000$ & $87,667,760$ \\
\hline 2019 & OCT & $85,287,000$ & & & & $100,828,000$ & $93,394,090$ \\
\hline 2019 & NOV & $100,828,000$ & $112,210,560$ & $2,269,918$ & $16,633,974$ & $110,333,000$ & $88,341,504$ \\
\hline 2019 & DEC & $110,333,000$ & $112,866,600$ & $2,175,686$ & $18,469,956$ & $121,907,000$ & $84,998,330$ \\
\hline 2020 & JAN & $121,907,000$ & $117,962,460$ & $2,269,255$ & $17,795,211$ & $125,938,000$ & $98,405,504$ \\
\hline 2020 & FEB & $125,938,000$ & $106,546,440$ & $2,029,981$ & $17,956,927$ & $138,615,000$ & $77,942,494$ \\
\hline 2020 & MAR & $138,615,000$ & $118,572,300$ & $2,079,909$ & $19,176,857$ & $132,658,000$ & $107,432,352$ \\
\hline 2020 & APR & $132,658,000$ & $93,822,960$ & $1,786,820$ & $17,426,844$ & $116,043,000$ & $94,797,936$ \\
\hline 2020 & MAY & $116,043,000$ & $86,837,520$ & $2,646,725$ & $16,334,346$ & $79,133,000$ & $110,059,899$ \\
\hline 2020 & JUN & $79,133,000$ & $110,898,480$ & $2,574,760$ & $12,065,428$ & $64,857,000$ & $115,683,812$ \\
\hline 2020 & JUL & $64,857,000$ & $109,572,540$ & $2,292,380$ & $12,713,010$ & $63,169,000$ & $100,839,911$ \\
\hline 2020 & AUG & $63,169,000$ & $108,163,440$ & $2,685,921$ & $12,485,091$ & $62,593,000$ & $98,940,269$ \\
\hline
\end{tabular}

